MATUS, Jean Pierre "Origen, consolidación y vigencia de la Nueva Dogmática Chilena (ca. 1955 1970)"

Polít. crim. Vol. 6, No 11 (Julio 2011), Art. 3, pp. 44 - 105.

[http://www.politicacriminal.cl/Vol_06/n_11/Vol6N11A3.pdf]

\title{
Origen, consolidación y vigencia de la Nueva Dogmática Chilena (ca. 1955 $\approx 1970)^{*}$ \\ Dr. Jean Pierre Matus A. \\ Prof. Titular de Derecho Penal de la Universidad de Chile jpmatus@derecho.uchile.cl
}

\section{Resumen}

El artículo describe la evolución de tres generaciones de profesores de Derecho penal chilenos, desde 1925 hasta 1970. Se indican las fuentes e influencias que reciben cada una de ellas y cómo influyen en las sucesivas generaciones, respectivamente. Se establecen las condiciones que incidieron en la eclosión de una gran cantidad de nuevos especialistas en Derecho penal en la generación de 1955-1970, denominada Nueva Dogmática Chilena, y su participación en la disputa entre el "sistema neoclásico" y la "teoría de la acción final". Se concluye con el análisis de la vigencia de sus aportes y de los efectos del Golpe de Estado de 1973 en su desarrollo posterior.

\section{Palabras clave}

Generaciones, profesores de Derecho penal chilenos, década de 1960, sistema finalista, sistema clásico.

\begin{abstract}
The following article describes the evolution of three generations of Chilean criminal law professors, from 1925 to1970. The sources and influences of each generation, and how they influence subsequent generations, are explained. Then, the conditions that influenced the emergence of a large number of new criminal law scholars of the 19551970 generation, known as the New Chilean Dogmatic, and their participation in the dispute between the "neoclassical system" and the "theory of final action", are established. The article concludes by examining the current relevance of the New Chilean Dogmatic's contributions and the effects of the 1973 coup in its further development.
\end{abstract}

\section{Key words}

Generations, Chilean criminal law professors, the 1960's, final action theory, classical system.

\footnotetext{
* Artículo resultado del Proyecto FONDECYT N 1090001, "Evolución de la doctrina penal chilena, desde el Código de 1874 hasta nuestros días. Análisis sincrónico y diacrónico. Segunda parte (periodo 1946-2007)", dirigido por su autor.
} 


\section{MATUS, Jean Pierre "Origen, consolidación y vigencia de la \\ Nueva Dogmática Chilena (ca. 1955 1970)"}

\section{Introducción}

Según se lee en La Ley y El Delito, Curso de Dogmática Jurídica, editado en Caracas en 1945 por don Luis Jiménez de Asúa, a esa fecha “...en Chile, Rafael Fontecilla, Pedro Ortiz, Abraham Drapkin y, últimamente, Luis Cousiño Mac Iver, estudian las características del delito con todo rigor científico". ${ }^{1}$

Y por "rigor científico", entendía en ese entonces Jiménez de Asúa, la "Dogmática", esto es, "la reconstrucción del Derecho vigente con base científica", esto es, según la metodología alemana, sin caer en la "confusión positivista" ni en el "estéril verbalismo" de la "Escuela técnico-jurídica", que repugna las cuestiones filosóficas que sirven de base a la labor dogmática. ${ }^{2}$

En 1957, en la segunda edición del Vol. 1 de su monumental Tratado de Derecho Penal, Luis Jiménez de Asúa señalaba que, a la fecha, en Chile, "la obra más completa y mejor sistematizada, dentro de su brevedad, es la segunda edición del derecho penal de Gustavo Labatut", agregando a la lista de quienes "se han apartado de las tendencias del positivismo" a "los más jóvenes penalistas", entre ellos, al profesor de la Universidad Católica, Eduardo Novoa Monreal; y a Álvaro Bunster, "Profesor de Derecho de la Universidad de Chile, que es sin duda la más henchida esperanza del nuevo penalismo chileno". 3

Quince años más tarde, al prologar en 1970 el Derecho penal chileno, parte especial, de Sergio Politoff, Juan Bustos y Francisco Grisolía, afirma, en cuanto a la bibliografía del momento, que

"En Chile se cuenta con dos obras completas: la de Gustavo Labatut y la de Alfredo Etcheberry, pero ambas tienen fundamentalmente destino docente. En cambio, el Curso de Derecho penal chileno, obra de méritos extraordinarios, de la que es autor Eduardo Novoa Monreal, sólo comprende, en sus dos volúmenes, la Parte general de nuestra disciplina."

Y en cuanto a los autores de la obra que prologa, los presentacalificándolos de "jóvenes penalistas chilenos", afirmando que en Chile "son muy conocidos" y que "en los pueblos de nuestra lengua no habrá penalista que no haya leído alguna de sus magistrales monografía", agregando que "incluso en Europa, donde los tres han estudiado, nadie que cultive el Derecho penal ignora su labor". A lo anterior añade no sólo un detallado recuento de las principales obras hasta entonces publicadas por Politoff, Bustos y Grisolía, todos a la fecha ya profesores de la Universidad de Chile, sino también un recuerdo personal que permite hacerse una idea del ambiente en que se desarrollaba la actividad dogmática en ese entonces:

\footnotetext{
${ }^{1}$ JIMÉNEZ DE ASÚA, Luis, La Ley y el Delito, Curso de Dogmática Penal, Caracas: Andrés Bello, 1945 , p. 254.

2 Íd., pp. 23 y 75.

3 JIMÉNEZ DE ASÚA, Luis, Tratado de Derecho Penal, T. I, $2^{a}$ ed. Actualizada, Buenos Aires: Losada 1957, p. 1103s. En este aspecto, la primera edición (1950) es idéntica.

${ }^{4}$ Prólogo, en POLITOFF, Sergio; BUSTOS, Juan; GRISOLÍA, Francisco, Derecho penal chileno, parte especial, T. I. Delitos contra el individuo en sus condiciones fisicas, Santiago: Ed. Jurídica de Chile, 1971, p. 8 .
} 
Polit. crim. Vol. 6, № 11 (Julio 2011), Art. 3, pp. 44 - 105.

[http://www.politicacriminal.cl/Vol_06/n_11/Vol6N11A3.pdf]

\begin{abstract}
"Cuando en febrero de 1966 fui de nuevo a Santiago...hube de sorprenderme sobremanera al ver el cambio favorable de sus bibliotecas y de sus penalistas. Era un prodigioso salto hacia delante que ponía a su copioso arsenal de libros y a sus jóvenes estudiosos, incluso por cima de los centros universitarios argentinos... pude medir el progreso que había hecho aquella mocedad penalista, tras de perfeccionar sus conocimientos en Alemania, Italia y España. Podían manejar un material bibliográfico moderno en alemán, italiano, francés y español, ya que tanto el Instituto de Ciencias penales, como el Departamento de Derecho penal de la Universidad, no habían reparado en gastos para atesorar los mejores libros y las colecciones de Revistas especializadas."
\end{abstract}

La nómina de aquella "mocedad penalista"puede encontrarse en la trascripción de las palabras de Francisco Grisolía leídas, en representación de las "nuevas generaciones" de penalistas, en el Acto Homenaje que en 1971 el Instituto de Ciencias Penales hiciera en memoria de Luis Jiménez de Asúa, fallecido en noviembre del año anterior. Allí menciona Grisolía como miembros de estas "nuevas generaciones" a Sergio Politoff, Alfredo Etcheberry, Sergio Yáñez, Luis Ortiz, Jaime Vivanco, Enrique Cury, Juan Bustos, Luis Bates, Antonio Bascuñán, Ricardo Rivadeneira, Felipe Amunátegui, Miguel Alex Schweitzer W., Marcelo Croxatto, Jaime Náquira y Jorge Mera. ${ }^{6}$

De este modo, es posible apreciar cómo en el lapso de apenas 25 años la lista de quienes "estudian el delito con todo el rigor jurídico" se había casicuadruplicado y, sobre todo, que ya alrededor de 1970 se asociaba este incremento a la emergencia de "nuevas generaciones".

El propósito general de este artículo es procurar distinguir con la mayor precisión posible, dentro del campo del Derecho penal, las "viejas" y "nuevas" "generaciones" aparecidas entre 1925 y 1970, mediante la delimitación de sus miembros y la precisión de las condiciones (eventos significativos, ámbito de referencia cognitivo y condiciones materiales) que originaron, más allá de las evidentes diferencias de edad, el cambio generacional. ${ }^{7}$ En particular, procuraremos mostrar cómo en ese lapso se prepararon las condiciones para el surgimiento de la que aquí denominamos Nueva Dogmática

\footnotetext{
${ }^{5}$ Íd., p. 9.

${ }^{6}$ GRISOLÍA, Francisco, “Jiménez de Asúa y las nuevas generaciones de penalistas”, Revista de Ciencias Penales, T.XXX (1971), pp. 9-11, p. 10.

${ }^{7}$ Se usa aquí el términos "generaciones" en el sentido sociológico, actualmente al uso (CRIADO, Martín, "Generaciones / Clases de Edad”, en REYES, Román (Dir.), Diccionario crítico de Ciencias Sociales, U. Complutense de Madrid, disponible en http:/www.ucm.es/info/eurotheo/diccionario/G/generaciones.htm [visitado el 1.3.2011], que deriva esencialmente de la obra de Mannheim, como puede verse en PILCHER, Jane, "Mannheim's sociology of generations: an undervalued legacy", British Journal of Sociology, Vol. 43, No 3 (1944), pp. 481-495. La extensión temporal de las generaciones que se plantea en el texto, de aproximadamente 15 años, se refiere únicamente al período en que ellas alcanzan la madurez en su formación universitaria y comienza su predominio en la discusión dogmática. Obviamente, ello supone una referencia a la coetaneidad y no a la contemporaneidad de cada generación, resultando así que el lector podrá percatarse de que autores incorporados a distintas generaciones pueden coexistir en un mismo momento histórico, lo cual es absolutamente necesario para el tránsito intergeneracional, base del esquema general de análisis. Por otra parte, ha de tomarse en cuenta que el tiempo asignado a cada generación de penalistas chilenos en el siglo XX es producto únicamente de las casualidades históricas en el campo del Derecho penal chileno y no deben verse como dependientes de la propuesta de los tres lustros de Ortega y Gasset (véase, al respecto, MARTÍNEZ DE CODES, Rosa María, "Reflexiones en torno al criterio generacional, como teoría analítica y método histórico", Revista Quinto Centenario (U. Complutense de Madrid), Vol. 3 (1982), pp. 51 a 86, pp. 71 y ss.).
} 
Chilena ${ }^{8}$ generación que entre 1955 y 1970 renovó la discusión en la materia. Para ello, estudiaremos el origen (1), condiciones de aparición (2), sus miembros y aportes a la discusión científica (3) y, finalmente, la vigencia (4) de quienes formaron parte de esta eclosión de la ciencia penal chilena en la década de 1960 .

\section{El origen}

\subsection{La primera generación de dogmáticos (autodidactas) chilenos (ca. 1925 1940)}

Como hemos expuesto en otro lugar, en Chile, ya a fines de la década de 1920 al menos un par de penalistas se habían apartado tanto de la enseñanza exegética del Derecho penal de Gallardo y Cabieses como del positivismo criminológico de Del Río, aproximándose al Derecho penal desde el punto de vista de la dogmática alemana de su época: Pedro Ortiz Muñoz, influido por la escuela de la Política Criminal de v. Liszt; y Rafael Fontecilla Riquelme, claramente influenciado no sólo por Liszt, sino también por sus lecturas directas de Binding y Beling. ${ }^{9}$ Como afirmaba Jiménez de Asúa, a esta breve lista se agregan Luis Cousiño Mac Iver, y algunos compañeros de una generación en que "la ausencia de enseñanza dogmática" no significaba "un desconocimiento o ignorancia total de los nuevos sistemas": ${ }^{10}$ Abraham Drapkin, Eduardo Erazo, Pedro Silva Fernández, Daniel Schweitzer S. y Miguel Schweitzer S. ${ }^{11}$

\footnotetext{
${ }^{8}$ La denominación es, naturalmente, sólo un "guiño" a la "nueva dogmática alemana", como se denomina a los "neoclásicos" en JESCHECK / WEIGEND, Tratado, cit. nota al pie $\mathrm{N}^{\circ} 42$, p. 220, pues su desarrollo va en otro sentido, como veremos más adelante.

${ }^{9}$ Sobre Raimundo del Río, el positivismo en Chile y su declive iniciado por la introducción por Ortiz y Fontecilla de las corrientes dogmáticas, véase MATUS, Jean Pierre, "El positivismo en el Derecho penal chileno. Análisis sincrónico y diacrónico de una doctrina de principios del siglo XX que se mantiene vigente", Revista de Derecho Universidad Austral (Valdivia), Vol. XX, No 1 (2007), pp. 175-203, especialmente pp. 186-190. Sobre la exégesis y la enseñanza del Derecho penal en Chile antes de 1925, véase MATUS, Jean Pierre, "Fernández, Fuenzalida y Vera: Comentaristas, autodidactas y olvidados. Análisis diacrónico y sincrónico de la doctrina penal chilena del siglo XIX", Ius et Praxis, Año 12, № 1 (2006), pp. 31-67, punto 4, y la nota al pie $\mathrm{N}^{\circ} 25$. En el Derecho penal, apuntes tomados en clase de don Ricardo Cabieses, ampliados y redactados por Roberto BELMAR, Pedro GANDULFO y Juan GUERRERO, aparecidos en Santiago: Imp. Estrella del Pacífico, 1918, 221 pp., se puede apreciar en qué consistía este método: en primer lugar, a una Introducción de 12 páginas en que se abordaba la denominación, definición y método de la disciplina, seguía la exposición más o menos ecuánime de las dos "Escuelas" del Derecho penal conocidas en Chile a ese época, la Clásica (a la cual adscribía el Profesor Cabieses), y la positiva (ambas abarcaban 40 páginas aprox.), una breve historia de la legislación penal chilena y comparada (15 páginas), y el grueso del texto (casi 120 páginas), dedicado a explicar y definir, artículo por artículo, en su mismo orden legal, el Libro I del Código penal, sirviendo cada uno de sus títulos de apartado: Así, se comienza esta parte del texto con el apartado "De los delitos i de las circunstancias que eximen la responsabilidad criminal, la atenúan o la agravan" (Título I del Libro I del Código) y se termina con el apartado "De la extinción de la responsabilidad penal" (Título V del Libro I del Código).

${ }^{10}$ COUSIÑO Mac Iver, Luis, "Influencia de Jiménez de Asúa en los penalistas chilenos", Revista de Ciencias Penales, T. XXX (1971), pp. 5-8, p. 6.

${ }^{11}$ JIMÉNEZ DE ASÚA, Tratado, cit. nota al pie no 3, menciona todavía en 1957 expresamente a Abraham Drapkin, como un "joven" con "talento" y "preparación", en la esperanza de que retornase de su periplo como embajador de Israel, cosa que no sucedió. A. DRAPKIN publicó entre 1936 y 1938 cinco artículos en la Revista de Ciencias Penales, de la cual fue Director en su "Primera Época", tres de ellos de marcado corte dogmático: "La menor edad" (T. III, 1937, pp. 53-29), "Defensa Legítima" (T. IV, 1938, pp. 36-56) y "Uxoricidio por adulterio" (T. IV, 1938, pp. 406-415). Sobre Eduardo Erazo, coautor con FONTECILLA de un Proyecto de Código Penal del año 1929, basado tanto en el positivismo criminológico como en la Escuela de Política Criminal de v. Liszt; así como sobre Pedro Silva, coautor en 1938, junto a Gustavo Labatut de un proyecto más bien "ecléctico", véase MATUS, Jean Pierre, "La doctrina penal de la (fallida) recodificación chilena del Siglo XX y principios del XXI", Política
} 
Polit. crim. Vol. 6, № 11 (Julio 2011), Art. 3, pp. 44 - 105.

[http://www.politicacriminal.cl/Vol_06/n_11/Vol6N11A3.pdf]

Todos ellos comparten una característica común con Fernández, Fuenzalida y Vera, nuestros comentaristas decimonónicos: son autodidactas, en el sentido de que no se formaron al alero de ningún profesor que haya sido determinante en su vocación por el Derecho penal, sino a través de sus propias lecturas. ${ }^{12}$

Así, por ejemplo, Pedro Ortiz Muñoz se tituló el año 1916, siendo su tesis "La ilegitimidad y la ley de matrimonio civil; reformas necesarias", tema bien alejado del Derecho penal. Posteriormente ingresó a la carrera judicial y siendo Juez de Letras en el Tercer Juzgado Civil de Santiago se le designó en una Comisión de Reforma del Código Penal durante la Dictadura de Ibáñez, trabajo del cual surgieron sus Nociones Generales de Derecho Penal, donde en su Prólogo declara no sólo las dificultades idiomáticas a que se enfrentó para comprender la obra de v. Liszt, sino su abierta admiración por la misma, al punto de copiar párrafos enteros de ella (lo que reconoce hidalgamente), ${ }^{13}$ de modo que parece acertada la crítica de Jiménez de Asúa, en el sentido que "la mayoría de sus páginas son un calco del Tratado de Franz von Liszt y carecen de originalidad alguna". 14

Con todo, no debe perderse de vista que, el propio Jiménez de Asúa califica su posterior Curso Breve de Derecho Penal (Común y Militar), ${ }^{15}$ como "libro muy estimable" y que el valor de su aporte a la formación de las futuras generaciones se debe principalmente al hecho de ponerlas en contacto con una teoría jurídica del delito de carácter dogmático, al modo de Escuela de Política Criminal alemana de v. Liszt, esto es, distinguiendo únicamente entre acción (como movimiento corporal), ilicitud (contrariedad objetiva con el derecho) y culpabilidad (de carácter primordialmente psicológico: dolo y culpa), en un "ambiente totalmente conquistado por la Escuela Positiva cuyos dioses Lombroso, Ferri y Garófalo, emitían destellos que deslumbraban

\footnotetext{
Criminal, Vol. $\quad 5, \quad \mathrm{~N}^{\mathrm{o}} 9 \quad$ (2010), $\quad$ Art. $4, \quad$ pp. $143-206$, en http://www.politicacriminal.cl/Vol 05/n 09/Vol5N9A4.pdf, pp. 172-178. Sobre Miguel Schweitzer Speisky, véanse la nota biográfica de Miguel SCHWEITZER W. y el texto de Álvaro FERNÁNDEZ, "Miguel Schweitzer Speisky: penalista", ambos en SCHWEITZER W., Miguel (Coord.), Nullum crimen, nulla poena sine lege. Homenaje a grandes penalistas chilenos, Santiago: Ed. U. Finis Terrae, 2010, pp. 16-18 y pp. 109-124, respectivamente. Allí se señala que habiéndose titulado en 1931, comenzó su carrera académica en la Universidad de Chile en 1935, siendo nombrado Profesor de Derecho penal en 1938, manteniendo toda su vida una activa condición de abogado litigante y catedrático, hasta su nombramiento como Profesor Emérito en 1980. Entre sus obras destacan los biógrafos su memoria de prueba "¿Debe castigarse al marido que mata a su cónyuge sorprendida en flagrante adulterio?” (Tesis UCh, 1935) y un artículo sobre la "reincidencia". En MATUS, Jean Pierre y CARNEVALI, Raúl, "Análisis descriptivo y cuantitativo de los artículos de Derecho penal y Criminología de autores chilenos en Revistas publicadas en Chile (1885-2006), Política Criminal No3 (2007), D2, pp. 1-138, p. 66 [http://www.politicacriminal.cl/n_03/d_2_3.pdf], pueden verse referidos tres artículos de Miguel Schweitzer S., aparecidos entre 1937 y 1945 en la Revista de Ciencias Penales, titulados "El delito de acusación o denuncia calumniosa" (T. III, 1937, pp. 342-359), "Síntesis de la legislación chilena de menores" (T. IV, 1938, pp. 310-316) y "El 'principio de ejecución' en el delito de violación” (T. VIII, 1945, pp. 25-28) ; y uno de su hermano Daniel, sobre "el Delito del artículo 212 del Código penal” (Revista de Ciencias Penales, T. XV (1956), pp. 5-8).

${ }^{12}$ Sobre esta peculiar características de nuestros primeros comentaristas, véase mi texto citado en la nota al pie No 9, "Fernández, Fuenzalida y Vera..."

${ }^{13}$ ORTIZ MUÑOZ, Pedro, Nociones Generales de Derecho Penal, T. I, Santiago: Editorial Nascimento, 1933.

${ }^{14}$ JIMÉNEZ DE ASÚA, Tratado, cit. nota el pie no 3, p. 1102.

${ }^{15}$ ORTIZ MUÑOZ, Pedro, Curso Breve de Derecho Penal (Común y Militar), Santiago: Imp. de Carabineros, 1947.
} 


\section{MATUS, Jean Pierre "Origen, consolidación y vigencia de la}

Nueva Dogmática Chilena (ca. 1955 1970)"

y enceguecían a quienes pretendían recorreren Chile la senda áspera del Derecho Penal."16

Este esfuerzo por difundir una teoría jurídica del delito en el adverso ambiente positivista tuvo sus frutos en el trabajo del Instituto de Ciencias Penales y, posteriormente, en la Universidad de Chile -donde enseñó la cátedra de Derecho penal en la Universidad de Chile ente 1928 y 1930 y desde 1937 hasta su fallecimiento en 1947-, ${ }^{17}$ según relata Luis Cousiño Mac Iver, ${ }^{18}$ y acredita uno de quienes, conociéndole, se declara su discípulo: Eduardo Novoa Monreal. ${ }^{19}$

Por su parte, Rafael Fontecilla realizó en 1914 su Memoria de Prueba también sobre un asunto de Derecho civil: Estudio sobre las expropiaciones por causa de utilidad pública. Aunque ya en su labor como Juez del Crimen comenzó a destacar su aproximación rigurosa al Derecho penal al calificar, en 1927, un hurto famélico como un caso de estado de necesidad, contra la opinión dominante de entender estas situaciones como supuestos de fuerza moral, lo que le valió el reconocimiento del propio Jiménez de Asúa, ${ }^{20}$ sólo a partir del encargo que se le hiciera en 1928 para la redacción de un Proyecto de Código penal comenzó a publicar obras relativas al Derecho penal, derivando posteriormente en el estudio del Derecho procesal penal. Al igual que en el caso de Labatut, ${ }^{21}$ Rafael Fontecilla transitó desde el positivismo hacia la dogmática, lo que resultó en su caso más fácil, dado que su positivismo era un derivado de la Escuela de Política Criminal de v. Liszt, como se ve reflejado en el Proyecto de Código Penal presentado en coautoría con Eduardo Erazo (1929), ${ }^{22}$ y su perfecto dominio del idioma alemán. ${ }^{23}$

\footnotetext{
${ }^{16}$ MONTERO S., Mario, "El pensamiento Jurídico Penal de Pedro Ortiz", Revista de Ciencias Penales, T. X(1948), pp. 110-130, p. 112.

${ }^{17}$ Más informaciones sobre Pedro Ortiz Muñoz, véanse en el texto citado en la nota anterior y en ABARZA, René, Pedro Pablo Ortiz Muñoz: vida obra einfluencia en el derecho penal chileno, Tesis UTal, Talca: 2005 (Prof. Guía: JP MATUS).

${ }^{18}$ COUSIÑO, Luis, "Pedro Ortiz Muñoz", Revista de Ciencias Penales, T. IX (1946), No 2, pp. iii-iv.

${ }^{19}$ NOVOA, Eduardo, "Pedro Ortiz Muñoz", Revista de Ciencias Penales, T. IX (1946), No 2, p. v-vi, p. $\mathrm{V}$.

${ }^{20}$ FONTECILLA, Rafael, "Luis JIMÉNEZ DE ASÚA y sus múltiples facetas", Revista de Ciencias Penales, T. XXX (1971), pp. 12-22, p. 21. En efecto, el texto de la sentencia de Fontecilla apareció citado, primero, en una de las innumerables notas publicadas por JIMÉNEZ DE ASÚA en la prensa, y luego en el T. IV de su Tratado, p. 446, nota al pie $\mathrm{N}^{\circ} 221$, donde se transcribe in extenso y se califica como la correcta doctrina en la materia.

${ }^{21}$ Ver nota al pie ${ }^{\circ} 57$.

${ }^{22}$ FONTECILLA R., Rafael, La pena, Santiago: Cisneros, 1931. El texto del proyecto se encuentra en su "Apéndice". Para un análisis del mismo, véase "La doctrina penal de la (fallida) recodificación", cit. nota al pie $\mathrm{n}^{\mathrm{o}} 11$, pp. 172-175.

${ }^{23} \mathrm{Y}$ tampoco le afectaban las carencias de las bibliotecas públicas de entonces. Ello se demuestra no sólo por las cuidadas citas a los textos originales en alemán que contiene el artículo y su sofisticado texto sobre Concursos, endonde abundan las citas directas de Berner, v. Buri, Liszt, Schmidt, Mezger, Honig, M. E. Mayer, Frank y Beling (FONTECILLA R., Rafael, Concursos de delincuentes, de delitos y de leyes penales y sus principales problemas jurídicos, Santiago: Editorial Jurídica de Chile, 1956. Los tres artículos que componen esta obra fueron primero publicados como "Apartados" de la Revista Penal de Buenos Aires, entre 1945 y 1946); sino también y sobre todo por su publicación en el idioma de Goethe de un reporte sobre el derecho penal chileno de la época en una colección editada en ese entonces por Mezger y JESCHECK, lo que, además, demuestra la alta estima y consideración que adquirió en el ámbito dogmático (FONTECILLA, Rafael, "Das chilenische Strafrecht", en MEZGER; SCHÖNKE (†); JESCHECK (Eds.), Das ausländische Strafrecht der Gegenwart, Berlín: Duncker \& Humblot, 1959, pp. 9-132).
} 
Polit. crim. Vol. 6, № 11 (Julio 2011), Art. 3, pp. 44 - 105.

[http://www.politicacriminal.cl/Vol_06/n_11/Vol6N11A3.pdf]

El paso hacia una "técnica jurídica" marcadamente influenciada por la dogmática penal alemana, fue, de este modo, natural, llegando a considerarse Fontecilla como el introductor en Chile del concepto de "tipicidad", en la fórmula de Beling. ${ }^{24}$

En efecto, Fontecilla ofrece en 1936 su conferencia "El Concepto Jurídico del Delito y Sus Principales Problemas Técnicos", donde declara que "el concepto jurídico del delito, que domina en la ley y en la doctrina, y que contenga los requisitos del mismo [...] están ausentes de la escuela clásica y de la positiva", por lo que se debe fijar la atención "en los tratadistas alemanes, que son los verdaderos maestros de la técnica". Sobre esta base, declara que la mejor concepción es la de Beling, "la cual alcanza el máximum de perfección técnica al expresar que era delito una acción típica, contraria al derecho, culpable y sancionada por una pena adecuada y suficiente a las condiciones objetivas de punibilidad". A ella agrega un concepto de "antijuricidad" tomado de la obra de M.E. Mayer, entendiéndola como "lo contrario a la norma de cultura admitida por el Estado". 25

Como hemos dicho, Fontecilla fue Juez y en la carrera judicial llegó a desempeñar el cargo de Presidente de la Corte Suprema entre 1960 y 1963. También fue miembro de numerosas organizaciones científicas nacionales y extranjeras y Profesor invitado de Derecho penal en la Facultad de Derecho de la Universidad de Chile los años 1927 y 1957 (donde dictó un curso profundizado y comparado) y Miembro Académico de la Facultad desde 1959 a $1967 .^{26}$

Finalmente, Luis Cousiño Mac Iver fue, a principios de la década de 1920, alumno de Ricardo Cabieses en la Universidad de Chile, quien "no se apartaba del método

\footnotetext{
${ }^{24}$ SCHWEITZER S., Miguel, "Discurso de recepción del profesor de derecho penal [Rafael Fontecilla]", Anales de la Facultad de Ciencias Jurídicas y Sociales, Vol. III, No 3 (1961 a 1963), p. 90.

${ }^{25}$ FONTECILLA R., Rafael, "El concepto jurídico de delito y sus principales problemas técnicos", Revista de Ciencias Penales, T. II (1936), p. 21-51, pp. 31-33 y 45. Antes, en un homenaje póstumo a Beling, ya había expuesto ideas similares ("Geheimer Rat Dr. Ernst von Beling (Dem Rektorat der Universität München als Beileidsbezeugung)", Anales de la Universidad de Chile (1933), primer trimestre, pp. 41-52). Después, en su Derecho Procesal Penal, cuya primera edición apareció en dos tomos el año 1943 (Santiago Imp. El Imparcial), con un laudatorio Prólogo de Luis JIMÉNEZ DE ASÚA, donde se le reconoce como "uno de los primeros hispanoamericanos que abandonan el positivismo" (pp. xix), Fontecilla desarrolla el concepto de tipicidad, como "condición de existencia del proceso penal" (p. 86s), en el sentido de "presupuesto procesal", identificándolo con la noción de "cuerpo del delito" o "hecho punible" (p. 87), pasando previamente revista a la evolución del concepto del "tipo" y sus diversas clasificaciones en la dogmática alemana del momento, reconociendo la existencia de "tipos con elementos normativos", que precisan "una valoración jurídica" más allá de la mera descripción (pp. 80-85). En la que aparece como segunda edición de este tratado, publicada en 1978 (Santiago: Ed. Jurídica de Chile, tres tomos) con adiciones de Marcos Libedinsky, el tratamiento de la materia se mantiene inalterable tanto en el contenido como en el aparato bibliográfico, salvo las adiciones del actualizador (T. II, pp. 131-144). Aunque éste señala que Fontecilla habría terminado alrededor de 1970 esta "segunda edición" (T. I, p. 21), me parece que, al menos en este punto, se trata más bien de una reimpresión del texto original con adiciones del actualizador, pues no me parece concebible que en un aspecto tan importante para su sistemática no existiese por parte de Fontecilla una revisión siquiera mínima de contenido y referencias bibliográficas, dada la época de su supuesta elaboración (30 años después de la primera edición), la importancia que la tipicidad como presupuesto del proceso penal adquiría en el autor, y su perfecto conocimiento del idioma alemán, amén de la sobrada literatura ya disponible en Chile durante la década de 1960.

${ }^{26}$ Para más detalles sobre Fontecilla, véase CABELLO, Carlos, Rafael Fontecilla Riquelme: Vida, obra e influencia en el Derecho Penal Chileno, Tesis UTal, Talca: 2005 (Prof. Guía: JP MATUS).
} 
exegético", ${ }^{27}$ lo que seguramente habrá motivado que su Memoria de Prueba no versase sobre Derecho penal, sino sobre un tema de naturaleza civil, La condición suspensiva, ${ }^{28}$ interesándose a tal punto por la materia que fue ayudante de la cátedra en la Universidad de Chile. Sólo quince años después de egresado comienza a publicar en materias penales, primero en relación a la medicina legal, ${ }^{29}$ y luego, derechamente, sobre aspectos dogmáticos, ${ }^{30}$ siendo el único de estos primeros precursores en la dogmática penal chilena que prolongó su producción en materias propiamente penales más allá del año 1940, llegando a publicar su Derecho penal chileno en tres tomos aparecidos en 1975, 1979 y 1992, ${ }^{31}$ obra cuyo primer tomo fue calificado como "valiosa obra, la de más largo aliento que se haya emprendido en nuestro medio". ${ }^{32}$ Ocupó desde 1941 a 1953 el cargo de Presidente del Instituto de Ciencias Penales, fue Abogado Integrante de la Corte Suprema hasta 1993 y Profesor de la Universidad de Chile, primero en la cátedra de Medicina Legal (1940), y luego en la Derecho penal, entre los años 1954 y $1971 .^{33}$

La larga vida de Cousiño Mac Iver y su permanente afán de actualización, permitieron su tránsito desde el descubrimiento de la dogmática alemana del "sistema clásico", en la forma expuesta por Jiménez de Asúa, ${ }^{34}$ característico de su generación, como veremos enseguida, hasta la recepción de las últimas ideas de Welzel acerca de la idea de acción cibernética, como un perfeccionamiento de la teoría final de la acción, a la que termina por adscribirse. ${ }^{35}$

\footnotetext{
${ }^{27}$ COUSIÑO Mac Iver, Luis, "Influencia de Jiménez de Asúa”, cit. nota al pie no 10, p. 5.

${ }^{28}$ COUSIÑO Mac Iver, Luis, De la condición suspensiva, Tesis UCh, Santiago: Imp. Santiago, 1926.

${ }^{29}$ Entre estos textos se cuentan: Herencia biológica y Derecho: Individualidad Biológica y en Especial Individualidad Sanguínea, Santiago: Editorial Nascimento, 1941; Breve Curso de Medicina Legal (para el uso de los alumnos del quinto año de las escuelas de derecho), Santiago: Politécnico de Menores Alcibíades Vicencio, 1941; y las cuatro ediciones (la primera de 1948), de su Manual de Medicina Legal, Santiago: Editorial Jurídica de Chile.

${ }^{30}$ Entre 1944 y 1950, aparecieron en la Revista de Ciencias Penales los siguientes textos Luis COUSIÑO Mac Iver: "La interpretación bio-psicológica del delito" (T. VII, 1944, pp. 301-314), "La falsificación de instrumento privado" (T. VII, 1944, pp. 5-23 y 99-131), y "Los delitos contemplados en la Ley de Cheques" (T. X, 1948, pp. 97-105). En la década de 1950 publicó otros textos relativos a aspectos procesales y, a partir de 1960, retoma los temas de dogmática penal con su "La interpretación de la Ley Penal en la dogmática chilena (T. XIX, 1960, pp. 197-218), "El delito socioeconómico” (T. XXI, 1962, pp. 47-63), y "El dolo eventual en la dogmática chilena” (T. XXVII, 1968, pp. 225-132). Su última publicación en la Revista de Ciencias Penales es del año 1974 (T. XXXIII, pp. 26-33) y trata sobre "Los integrantes subjetivos de la justificación”.

${ }^{31}$ Todos los tomos fueron publicados en Santiago por la Editorial Jurídica de Chile, existiendo la siguiente advertencia en cuanto a sus fechas, expuesta en la p. 3 del T. I: este primer tomo se terminó de elaborar a mediados de 1973, pero sólo aparece publicado en 1975. El autor no lo menciona, pero es evidente que el cambio institucional producido por el Golpe de Estado de 1973 retrasó su publicación (lo que no significa que Cousiño fuese opositor al régimen militar, sino todo lo contrario, ocupando durante el mismo cargos políticos de relativa importancia, como el de Miembro del Consejo Nacional de Televisión en la década de 1980).

${ }^{32}$ YÁÑEZ, Sergio, "Comentario del Libro Derecho Penal Chileno: Parte General (Tomo I)", Revista de Ciencias Penales, T. XXXIV, No 2 (1975), p. 240.

${ }^{33}$ Más informaciones sobre Luis COUSIÑO Mac Iver, véanse en OPAZO, Cristián, Luis Cousiño Mac Iver: Vida, obra e influencia en el Derecho Penal actual, Tesis UTal, Talca: 2006 (Prof. Guía: JP MATUS). ${ }^{34}$ COUSIÑO, "Influencia", cit. nota al pie $\mathrm{n}^{\circ} 27$, p. 7 , donde reconoce a JIMÉNEZ DE ASÚA como maestro que le enseñó "todos los problemas modernos de la dogmática", recordando haber "devorado" sus libros de editados en Latinoamérica e, incluso, haber llegado a recurrir a una tirada "a mimeógrafo" de los apartados más importantes de la "Teoría Jurídica del Delito" (que apareció en Madrid, en 1931), de la cual no existían suficientes ejemplares en Chile.

${ }^{35}$ COUSIÑO Mac Iver, Luis, Derecho penal chileno, T. I, Santiago: Ed. Jurídica de Chile, 1975, p. 466,
} 
Polit. crim. Vol. 6, № 11 (Julio 2011), Art. 3, pp. 44 - 105.

[http://www.politicacriminal.cl/Vol_06/n_11/Vol6N11A3.pdf]

\title{
1.2. La influencia de Jiménez de Asúaen la primera generación de dogmáticos chilenos y la introducción en Chile del "sistema tradicional" ("neoclásico") alemán
}

\subsubsection{Jiménez de Asúa, "el maestro de todos"}

Como hemos apuntado, a diferencia de los comentaristas autodidactas del siglo XIX, los precursores de la labor dogmática en Chile contaron con un elemento que permitió despertar y reforzar su vocación por una forma de aproximarse al Derecho penal diferente tanto de la exégesis de Cabieses como del positivismo de Del Río: la omnipresencia de Luis Jiménez de Asúa, con su traducción de v. Liszt, sus múltiples obras impresas, visitas y conferencias dadas en la Universidad de Chile desde la década de 1920 y hasta la de 1960.

En efecto, según Luis Cousiño Mac Iver, se puede afirmar, "sin exageraciones ni equívocos", que para esta primera generación de penalistas "dogmáticos" chilenos,

\begin{abstract}
"su influencia fue tan destacada y penetrante, al enseñarnos todos los problemas modernos de la dogmática a la luz de la doctrina de los tratadistas más destacados en el mundo entero y de la suya propia, que se convirtió en el maestro de todos los cultores de esta rama del derecho tan desvalida en su aspecto propiamente jurídico [...] quien nos hablaba de los elementos del delito en forma científica, organizada y metódica [...] y que, al mismo tiempo, dictaba conferencias sobre causales supralegales de justificación, de no exigibilidad de otra conducta, de conflicto aparente de leyes, de elementos subjetivos de lo injusto, de condiciones objetivas de punibilidad y del problema, tan polémico, de la unidad y pluralidad delictual."36
\end{abstract}

Así, relata Miguel Schweitzer S. en el Discurso con que se recibió a Jiménez de Asúa como Miembro Honorario del Instituto de Ciencias Penales en Noviembre de 1942, que éste visitó Chile por primera vez en 1925; luego, en 1928, dictando una conferencia sobre "homicidio piadoso o eutanasia; y posteriormente, tras su destierro en Argentina, en 1940, para dar cuatro lecciones sobre los "Elementos del Delito" en la Universidad de Chile; siendo el año 1941 aquél en que prodigó más visitas, como delegado de la Universidad de la Plata al Segundo Congreso Latinoamericano de Criminología, como invitado de la Escuela de Verano de la Universidad de Chile, y como conferenciante del Instituto de Ciencias Penales, donde dictó el curso de "Interpretación de la Ley Penal" y en 1941 , en varias ocasiones. ${ }^{37}$

nota al pie 892, y pp. 464 a 483. Es interesante destacar que en esta obra, desprendida de su generación, Cousiño mantiene ciertos puntos de partida propios de la formación "clásica", como su tajante distinción entre el delito como un hecho humano ontológico, un todo objeto de calificación penal, y su valoración deontológica o calificación como delito, donde los elementos abstractos de esta valoración (tipicidad, antijuridicidad y culpabilidad) adquieren una dimensión, hoy diríamos, puramente normativa, significativa exclusivamente para el Derecho (y por tanto para la calificación del hecho como delito), pero que no altera la realidad del hecho valorado como un todo. (pp. 261-266). De allí que Cousiño estime que el concepto final de acción es más adecuado para describir "la categoría ontológica de acción" que el "concepto jurídico-penal de la acción", que "pertenece por completo a la tipicidad, en tanto y en cuanto son los tipos los que describen las acciones" (p. 438), lo que también es parte de las tradicionales críticas del sistema clásico a la teoría final de la acción, como veremos más adelante. También se aparta Cousiño de la ortodoxia finalista, pues no realiza una diferenciación sistemática entre el injusto doloso y el culposo, tratando ambos dentro de una exposición unitaria de la tipicidad (pp. 642 y ss).

${ }^{36}$ COUSIÑO, "Influencia", cit. nota al pie n' 27, p. 7.

${ }^{37}$ SCHWEITZER S., Miguel, "Discurso pronunciado por el señor Miguel Schweitzer S., en el Instituto de Ciencias Penales, al ser recibido como Miembro Honorario el Profesor Sr. Luis Jiménez de Asúa, en la sesión de fecha 26 de noviembre de 1942", Revista de Ciencias Penales, T. XXX, No 1 (1971), pp. 38-40, 
De este modo entraron en contacto personal y científico con el Maestro español no sólo su discípulo avecindado en Valparaíso, Manuel de Rivacoba y Rivacoba, ${ }^{38}$ y los citados Cousiño y Schweitzer S., sino también Fontecilla -a quien Jiménez de Asúa consideraba un amigo personal- ${ }^{39}$ y Labatut, encargado de recibirlo como Miembro Honorario de la Facultad de Ciencias Jurídicas y Sociales de la Universidad de Chile en el mismo año 1942, quien con estas palabras aclara el peso de la obra de Jiménez de Asúa en ese momento:

\begin{abstract}
"Sus trabajos representan obligadas fuentes de consulta para todos los que cultivan el derecho penal, y será raro encontrar alguna publicación hispanoamericana sobre cuestiones penales, en que su nombre no aparezca citado, no una, sino multitud de veces". 40
\end{abstract}

Es por ello que el Consejo de la Facultad de Derecho de la Universidad de Chile, al conocerse el fallecimiento de Jiménez de Asúa, acordó enviar a su viuda un Oficio de fecha 1 de diciembre de 1970, firmado por los entonces Decano, don Eugenio Velasco, y Secretario de la Facultad, don Luis Cousiño Mac Iver, en el cual, en lo que aquí interesa, se lee lo siguiente:

\begin{abstract}
"La influencia del maestro se dejó sentir en nuestras aulas, a las cuales él concurrió en todas las oportunidades en que estuvo en Chile, pero esta influencia se ejercitó, especialmente, sobre los maestros de Derecho Penal de las actuales generaciones, en quienes su espíritu de investigación, sus lecciones y su ejemplo fueron el más fuerte estímulo para los cambios operados en los últimos treinta años en las posiciones doctrinarias, en los programas y en los sistemas de enseñanza." ${ }^{41}$
\end{abstract}

1.2.1. El "sistema tradicional" ("neoclásico"), en la versión que Luis Jiménez de Asúa introduce en Latinoamérica

Hoy es común encontrar en los textos al uso una distinción entre el "sistema clásico" de Liszt-Beling, basado en un estricto positivismo jurídico,y el "neoclásico" cuyo principal representante sería Edmund Mezger, basado en la filosofía "neokantiana" de boga en el segundo cuarto del siglo $\mathrm{XX} .^{42}$

\footnotetext{
p. 39.

${ }^{38}$ Sobre Manuel de Rivacoba y Rivacoba, véanse las extensas "semblanzas y evocaciones" que suscriben POLAINO NAVARRETE, M. ("Semblanza personal y universitaria de Manuel de Rivacoba y Rivacoba (1925-2000)"), LUISI, Luiz ("La figura de Manuel de Rivacoba y Rivacoba"), Valencia Martínez, Jorge ("Recuerdo de Manuel de Rivacoba y Rivacoba") y GUZMÁN DALBORA, José Luis ("Un ejemplo de coherencia") en GUZMÁN DALBORA, José Luis (Coord.), El penalista liberal. Controversias nacionales e internacionales en Derecho penal, procesal penal y Criminología, Buenos Aires: Hammurabi, 2004, pp. 19-54.

${ }^{39}$ FONTECILLA, Rafael, "Luis Jiménez de Asúa", cit. nota al pie no 20, p. 21. Así lo confirma el Prólogo de JIMÉNEZ DE ASÚA al Derecho Procesal Penal de FONTECILLA, del año 1942 (cit. nota al pie $\mathrm{n}^{\circ} 25$ ), y la dedicatoria de puño y letra del ejemplar que poseo del texto de La Ley y el Delito, cit. nota al pie $n^{\circ} 1$, donde su autor escribe: "a Rafael Fontecilla, amigo entrañable, con un gran abrazo, Luis Jiménez de Asúa, Bs. Aires, 17-XII-45".

${ }^{40}$ LABATUT G., Gustavo, "Discurso pronunciado por don Gustavo Labatut G. En la recepción de don Luis Jiménez de Asúa como Miembro Honorario de la Facultad de Ciencias Jurídicas y Sociales de la Universidad de Chile", Revista de Ciencias Penales, T. XXX, No 1 (1971), pp. 40-42, p. 42.

${ }^{41}$ En Anales de la Facultad de Derecho, Cuarta Época, Vol. XI (Año 1970), No 11, p. 71.

42 JESCHECK, Hans H.; WEIGEND, Thomas, Tratado de Derecho Penal, Parte General, Trad. de la $5^{\mathrm{a}}$ ed. Alemana (1996) por M. Olmedo, Granada: Comares, 2002, p. 219.
} 
El "sistema clásico", en una de las últimas y más sintéticas elaboraciones de Beling, se caracterizaría por entender el delito como "acción típicamente antijurídica y culpable", donde la acción se entendía como "un comportamiento corporal voluntario", la tipicidad ("adecuación al catálogo de tipos delictivos", sin predicado valorativo) y la antijuridicidad (valoración jurídica de dicha acción típica como "objetivamente en contradicción con el orden jurídico") abarcaban sus aspectos objetivos; y la culpabilidad, todo lo subjetivo, incluyendo la imputabilidad y el dolo y la culpa, esto es, "un juicio valorativo sobre la fase interna (espiritual o "subjetiva") de la acción: en la subjetividad del autor no se ha examinado como debiera haberse hecho, conforme a las exigencias del orden jurídico, y por esa diferencia le es "reprochable" su acción". ${ }^{3}$

En cambio, el sistema "neoclásico", sin alterar la estructura del anterior, modifica sus contenidos desde un punto de partida filosófico conocido como "neokantismo", en que se entendía al Derecho como una "ciencia de los valores" y no de la naturaleza o de la mera legalidad positivista o "voluntad de la ley". ${ }^{44}$ Así, por ejemplo, para Mezger, sobre la base de una definición muy similar de delito como "acción típicamente antijurídica y culpable", afirma que "el hacer y el omitir punibles, no sólo son conceptos contradictorios de un suceder externo, sino también conceptos referidos a un valor", esto es, "conductas humanas valorizadas de una determinada manera". Respecto de la tipicidad, considera que no es independiente de la antijuridicidad, sino que afirma que "una acción que cae bajo un tipo legal es antijurídica en tanto no concurra una especial causa de exclusión del injusto", por lo que no habría una real distinción entre ambos conceptos, ya que un tipo penal no valorado no sería concebible en esta teoría. Tipo es "el injusto descrito concretamente por la ley ensus diversos artículos, y a cuya realización va ligada la sanción penal"; mientras un injusto sería una acción que "contradice las normas objetivas del Derecho". Finalmente, en cuanto a la culpabilidad, Mezger reconoce el concepto general de Beling, en el sentido de concebirla como "el

\footnotetext{
${ }^{43}$ BELING, Ernst v., Esquema del Derecho penal / La doctrina del delito-tipo, Trad. de las ediciones alemanas de 1930 por S. SOLER, Buenos Aires: Depalma, 1944, pp.19, 21., 30 y 38. Uso esta versión porque, dado que se encuentra en castellano y editada en Argentina, es posible que a ella tuviesen acceso directo nuestros penalistas de la época. En cambio, respecto del texto de 1906, Die Lehre von Verbrechen, sólo se tendrían referencias indirectas (básicamente a través de Jiménez de Asúa). Con todo, se debe destacar que entre ambos textos hay ciertas diferencias, partiendo por el concepto de delito, según lo cita el mentado JIMÉNEZ DE ASÚA: "la acción típica antijurídica, culpable, sometida a una adecuada sanción penal y que llena las condiciones objetivas de penalidad" (La ley y el delito, cit. nota al pie n 39, p. 254). Para una detallada explicación de la teoría original de Beling, véase CARDENAL M., Sergi, El tipo penal en Beling y los neokantianos, U. De Barcelona: Tesis Doctoral, 2002, pp. 29-82, con extensas citas al texto original de Beling (disponible en Internet en http://www.tdr.cesca.es/TESIS UB/AVAILABLE/TDX-0604102-083801/TOL77.pdf [visitado el 01.03.2011]). Kai AMBOS ha propuesto recientemente que la estructura analítica propuesta por Beling hace ya más de cien años parece encontrarse en el sustrato del actual Derecho penal internacional, asimilándola a la teoría del delito del Common Law ("100 años de la <<teoría del delito>> de Beling ¿renacimiento del concepto causal del delito en el ámbito internacional?”, Revista Electrónica de Ciencias Penales y Criminología, 09-05 (2007), pp. 05:01-05:15, disponible en internet en http://criminet.ugr.es/recpc/09/reccpc09-05.pdf). Sin embargo, como he demostrado anteriormente, esta comparación, que parece tener el propósito de calificar como "atrasada" o "anticuada" la teoría del delito del Common Law, está equivocada en sus fundamentos (véase MATUS, Jean Pierre, La transformación de la Teoría del Delito en el Derecho penal internacional, Barcelona: Atelier, 2008, p.19, nota 7).

${ }^{44}$ Así lo señala claramente Mezger al exponer los fundamentos metodológicos de su doctrina: "el principal avance en el moderno pensamiento jurídico es la superación del positivismo del cambio de siglo y del siguiente primer decenio por el punto de vista ontológico" (MEZGER, Edmund, Moderne Wege der Strafrechtsdogmatik. Eine ergänzende Betrachtung zum Lehrbuch des Strafrechts in seiner 3. Auflage (1949), Berlín: Duncker\&Humblot, 1950, p.7, el destacado es del autor).
} 


\section{MATUS, Jean Pierre "Origen, consolidación y vigencia de la Nueva Dogmática Chilena (ca. 1955 1970)"}

conjunto de aquellos presupuestos de la pena que fundamentan, frente al sujeto, la reprochabilidad personal de la conducta antijurídica", incluyendo una base psicológica "en la que se conecta el reproche contra el autor" (dolo y culpa), pero agregando que "es, al mismo tiempo y siempre, un juicio valorativo sobre la situación fáctica de culpabilidad", acogiendo así la llamada concepción normativa de la culpabilidad. ${ }^{45}$

Se atribuye a Jiménez de Asúa haber introducido en España el estudio de la teoría jurídica del delito en la forma del "sistema clásico", en su obra La teoría jurídica del delito, aparecida en Madrid, en $1931{ }^{46}$ Sin embargo, como ya se ha apuntado, esa obra no estuvo completamente a disposición de nuestros primeros dogmáticos. ${ }^{47}$ Por eso hemos de examinar aquí la obra de Jiménez de Asúa que con el subtítulo de Curso de dogmática penal apareció publicada en 1945 y sabemos llegó a las manos de nuestros primeros dogmáticos, ${ }^{48}$ donde se puede observar que en ella no hay un distingo de sistemas, sino una exposición de un único "sistema tradicional" o "teoría jurídica" que habría sufrido una casi "natural" evolución hasta su estado en ese entonces, y así se señala que

“desechada la confusión que engendró el positivismo y restablecido el valor de la dogmática, ha renacido en Italia, España y varios países de Hispanoamérica, la teoría jurídica del delito, que jamás se abandonó en Alemania, Suiza y Suecia”. ${ }^{9}$

A continuación, procede Jiménez a describir "el concepto de delito según Beling, Mayer y Mezger" y el suyo propio como parte de este continuo ("acto típicamente antijurídico culpable, sometido a veces a condiciones objetivas de penalidad, imputable a un hombre y sometido a una sanción penal"). ${ }^{50}$

Así, los contenidos de los elementos del delito, debido a la antes mencionada idea de la continuidad en el desarrollo dogmático "tradicional", parecen permanecer, en ese momento de la vida de Jiménez de Asúa, todavía en su mayor parte anclados en el "sistema clásico", mientras otros parecen propios del "neoclásico", sobre todo en cuanto al aspecto metodológico de su concepto de derecho y un par de cuestiones sistemáticas y conceptuales, en las que claramente se ve la influencia de Mezger y M. E. Mayer. ${ }^{51}$

\footnotetext{
${ }^{45}$ MEZGER, Edmund, Tratado de Derecho Penal, 2 Tomos, Trad. de la $2^{\mathrm{a}}$ ed. Alemana (1932) por J. RODRÍGUEZ MUÑOZ, Madrid: Edersa, 1946, T. I: pp. 161, 188, 327, 352; T. II: pp. 1-5.

${ }^{46}$ JESCHECK / WEIGEND, Tratado de Derecho Penal, cit. nota al pie no 42, p. 218, nota 27, in fine. Recientemente este trabajo ha sido reeditado en España (Madrid: Dykinson, 2005), con un estudio preliminar y un epílogo de E. Bacigalupo donde se califica la conferencia que se transcribe en el texto como el momento del "nacimiento de la dogmática de habla castellana" (p. VII).

${ }^{47}$ Ver nota al pie ${ }^{\circ} 20$.

${ }^{48}$ Así lo atestiguan tanto la dedicatoria autografiada del ejemplar que perteneció a Rafael Fontecilla, como el recuerdo de Francisco Grisolía, quien en 1971 decía: "conservo con cariño y esmero, si bien bastante deteriorado por el uso intenso a que fuera sometido, el ejemplar de la edición príncipe de "La ley y el delito" que me sirviera de texto de estudio cuando cursé la materia en 1950. Este libro, junto a las lecciones de mi profesor Miguel Schweitzer, fueron sin duda determinantes en mi vocación" (GRISOLÍA, "Jiménez de Asúa ...", cit. nota al pie no 6, p. 10).

${ }^{49}$ JIMÉNEZ DE ASÚA, La ley y el delito, cit. nota al pie n 39, p. 253.

${ }^{50}$ JIMÉNEZ DE ASÚA, La ley y el delito, cit. nota al pie no 39, pp. 254 a 256. Opuesto a este "sistema tradicional", aparece en la obra de Jiménez de Asúa sólo "la moda" que asocia al autoritarismo de la Alemania nacionalsocialista de ese momento, y que "pretende acabar con la división de requisitos marcados y quiere proclamar la unidad del delito o su indole de totalidad o conjunto" (p. 256).

${ }^{51}$ Otro de los autores asociados al "sistema neoclásico", como puede verse en el Prólogo de GUZMÁN DALBORA a la reciente traducción del texto de MAYER, Max Ernst, Derecho penal. Parte general
} 
Polit. crim. Vol. 6, № 11 (Julio 2011), Art. 3, pp. 44 - 105.

[http://www.politicacriminal.cl/Vol_06/n_11/Vol6N11A3.pdf]

Así, afirma que "la dogmática ha de edificarse sobre el Derecho vigente y no sobre la mera ley", en una alusión indirecta contraria al positivismo de v. Liszt y Beling, agregando que "el Derecho abarca también las vivencias del pueblo que rige" y que

"hay un Derecho supralegal al que a menudo tenemos que acudir para establecer los conceptos positivos y negativos de la antijuricidad; es decir, de lo injusto, y de las causas de justificación, así como para individualizar la culpabilidad que en su aspecto negativo se corona con la causa general de exclusión que se denomina en Alemania 'no exigibilidad de otra conducta"'. ${ }^{2}$

El esquema analítico de la teoría del delito propuesto por Jiménez de Asúa, conforme a su concepto del mismo, es el siguiente: ${ }^{.3}$
Aspecto Positivo
a) Actividad
Aspecto Negativo
b) Tipicidad
a) Falta de Acción
c) Antijuricidad
b) Ausencia de tipo
d) Imputabilidad
c) Causas de justificación
e) Culpabilidad
d) Causas de inimputabilidad
f) Condicionalidad
objetiva
g) Punibilidad
e) Causas de inculpabilidad
f) Falta de condición objetiva
g) Excusas absolutorias

En el detalle, el sistema presentado por Jiménez de Asúa en la década de 1940 considera acción como "manifestación de la voluntad que, mediante acción u omisión, causa un cambio en el mundo exterior"; la tipicidad como la "descripción legal [del hecho] desprovista de carácter valorativo", en la versión original de Beling, aceptando que, en algunos casos, "los tipos contengan elementos normativos y subjetivos de lo injusto"; la antijuridicidad como la "valoración objetiva con la norma" de la acción típica, que "es independiente del dolo" y que se fundamentaría en la teoría de las "normas de cultura" de M. E. Mayer. ${ }^{54}$ En cuanto a la imputabilidad, la separa de su tratamiento "clásico" en la teoría de la culpabilidad y ofrece una noción de ella más bien novedosa y basada en

(1915), Trad. S. POLITOFF, Montevideo: B de F, 2007, pp. XII, donde se considera al autor, junto a Radbruch, representantes del "cenit del neokantismo"; y en JESCHECK / WEIGEND, Tratado de Derecho Penal, cit. nota al pie ${ }^{\circ} 42$, p. 220, nota al pie 33.

${ }^{52}$ JIMÉNEZ DE ASÚA, La ley y el delito, cit. nota al pie n 39, p. 258.

${ }^{53}$ JIMÉNEZ DE ASÚA, La ley y el delito, cit. nota al pie $\mathrm{n}^{\circ} 39$, p. 259 reconoce aquí que la base del esquema la ha tomado de Sauer, antes de su "despeño" en apoyo del nacionalsocialismo. De todos modos, el esquema no parece muy semejante al complejo sistema que publica SAUER posteriormente y aparece en su Derecho Penal (Parte General), Barcelona: Bosch, 1956, Trad. de J. Del ROSAL y J. CEREZO MIR de la $3^{\text {a }}$ ed. alemana de 1955. En todo caso, se debe hacer notar la semejanza de este modo de exponer los elementos del delito con el propuesto casi 40 años después por Eser, para hacerlos inteligibles al público anglosajón (ESER, Albin, "Justification and Excuse: A Key Issue in the Concept of Crime", en ESER, A.; FLETCHER, G., Rechtfertigung und Entschuldigung. Bd. I, Freiburg i. Bgr.: Max-Planck Institut für ausländisches und internationals Strafrecht, 1987, p. 62.

${ }^{54}$ Al respecto, véase M. E. MAYER, Derecho penal, cit. nota al pie $\mathrm{n}^{\circ}$ 51, pp. 55-71, donde se afirma que "las normas de cultura son prohibiciones y mandatos a través de los cuales una sociedad exige una conducta adecuada a sus intereses" (p. 55), normas cuyo "conflicto" es "inevitable" y "fructífero" (p. 60) y que por ello requieren un "reconocimiento" del Estado, son el "material" para la elaboración de la "norma jurídica" (p. 61), pues "la delimitación de la conducta lícita de la conducta ilícita se lleva a cabo en la legislación a través del reconocimiento de las normas de la cultura" (p. 63). De allí que Mayer termina definiendo el delito como "un acontecimiento imputable que corresponde a un tipo legal y que es contradictorio con una norma de cultura reconocida por el Estado" (p. 71). 
la psicología de la época, adoptando el concepto de M.E. Mayer, y definiéndola como "la posibilidad condicionada por la salud mental y el desarrollo del autor, para obrar según el justo conocimiento del deber existente". Y finalmente, respecto de la culpabilidad, acepta el concepto normativo en la forma recogida por Mezger, como "la expresión jurídicamente desaprobada de la personalidad", pero rechaza el tratamiento que este autor hace de sus elementos, en particular del dolo y la culpa, pues afirma que "el dolo y la culpa son especies y no caracteres de la culpabilidad". 55

Un par de décadas más tarde, en el año 1965, Jiménez de Asúa hace suya, en la tercera edición de su Tratado, la distinción entre el sistema de Liszt y Beling, que entonces se calificaba de "positivismo científico" o "legal" y "la teoría que aparece tras de la primera guerra mundial y que se denominó sistema teleológico", en la que enmarca a Mezger y M.E. Mayer. Aquí da cuenta, además, de su admiración por el sistema de Liszt y Beling, debido a que "cada elemento del delito ofrecía un papel tan definido como propio", del surgimiento de la teoría final de la acción y de las críticas que entiende pueden hacerse a ella, resaltando "la vuelta a la sistemática ortodoxa" $\mathrm{y}$, en consecuencia, de la ordenación de "los caracteres del delito de la manera que puede llamarse tradicional", que es la que asume en definitiva, pues tanto su concepto de delito como el esquema para su análisis que ofrece en este momento no varía en absoluto del contenido en su texto de $1945 .^{56}$

\subsection{El legado de la primera generación de dogmáticos en la formación de la Nueva Dogmática Chilena}

\subsubsection{La labor del Seminario de Derecho Penal y Medicina Legal de la Facultad de Ciencias Jurídicas y Sociales de la Universidad de Chile}

Al contrario de los comentaristas del siglo XIX, hemos visto que buena parte de los primeros dogmáticos nacionales sí consiguieron ser profesores de la Facultad de Derecho de la Universidad de Chile. Allí participaron de la formación y consolidación de su Seminario de Derecho Penal y Medicina Legal, creado en 1935, y cuyo primer Director fue Gustavo Labatut Glena (quien ejerció el cargo hasta su muerte, en 1963). ${ }^{57}$ Aunque Labatut no era propiamente un dogmático de raigambre alemana, se acercaba al "sistema tradicional" desde la Escuela de la Técnica Jurídica italiana, ${ }^{58}$ y su Derecho

\footnotetext{
55 JIMÉNEZ DE ASÚA, La ley y el delito, cit. nota al pie no 39, pp. 260, 293, 351s, 410, 421, 447 y 450.

${ }^{56}$ JIMÉNEZ DE ASÚA, Tratado de Derecho penal, T. III, El delito, $3^{a}$ ed. Actualizada, Buenos Aires: Losada, 1965, pp. 63, 315 y ss. y 320 y ss., donde se transcriben el concepto y esquema de 1945, antes citados.

57 "Memoria del Seminario de Derecho Penal y Medicina Legal", año 1965, en Anales de la Facultad de Derecho, Cuarta Época, Vol. IV (Años 1964 - 1965), Nº 4, p. 162. Por su destacada labor de más de 30 años como Director, "como homenaje póstumo, la Facultad acordó perpetuar su obra colocando al Seminario de Derecho Penal y Medicina Legal el nombre de "Gustavo Labatut Glena"' (Anales de la Facultad de Derecho, Cuarta Época, Vol. III (Años 1961 a 1963), No 3, p. 203. De ese homenaje queda hoy en día una fotografía a la entrada de la sala de reuniones del actual Departamento de Ciencias Penales.

${ }^{58}$ Según se demuestra en MATUS, "La (fallida) reforma...", cit. nota al pie no 11, pp. 175-178, especialmente nota el pie $\mathrm{n}^{\mathrm{o}} 122$ en p. 175. Véase también ESPINOZA H. Mauricio, Gustavo Labatut Glena: vida, obra y aporte al Derecho penal actual, Tesis UTal, Talca: 2005 (Prof. Guía: JP MATUS). Sobre la influencia en Chile de los criminalistas italianos, véase, con detalle, CARNEVALI, Raúl, "La ciencia penal italiana y su influencia en Chile", Política Criminal, No 6 (2008), A4-6, pp. 1-19, en: http://www.politicacriminal.cl/n_06/a_4 6.pdf [visitado el 1.3.2011], especialmente pp. 11 a 16, donde se señala que la ciencia jurídica italiana, en la forma de la "Dirección Técnico-Jurídica" no sólo habría
} 
Polit. crim. Vol. 6, № 11 (Julio 2011), Art. 3, pp. 44 - 105.

[http://www.politicacriminal.cl/Vol_06/n_11/Vol6N11A3.pdf]

penal, sobre todo a partir de su segunda edición, era elogiado por Jiménez de Asúa, por considerarlo una obra "correctamente sistematizada", que "aclara muchas cuestiones del ordenamiento penal chileno". 59

El Seminario de Derecho Penal y Medicina Legal se creó con fecha 3 de septiembre de $1934^{60}$ y comenzó a funcionar en 1935, en el marco de un importante proceso de reforma de la enseñanza del Derecho, iniciado en $1933 .{ }^{61}$ Como ya hemos señalado, su primer Director fue don Gustavo Labatut Glena. El año 1937 figuraban como Profesores de Derecho Penal del mismo, su Director, don Raimundo del Río, don Pedro Ortiz Muñoz y don Miguel Schweitzer S. ${ }^{62}$ En 1940 se incorporó al Seminario, primero como Profesor de Medicina Legal y luego como Profesor de Derecho Penal, Luis Cousiño Mac Iver. ${ }^{63}$ También dictó clases y ofreció un curso profundizado don Rafael Fontecilla en 1957, aunque su período más regular fue entre 1959 y 1967. Finalmente, se incorporaría a la Facultad, como "Miembro Académico", Pedro Silva Fernández, el año 1961. ${ }^{64}$ De donde se puede colegir que, desde sus inicios, en el Seminario existió una mayoría de dogmáticos "tradicionales" y "técnicos jurídicos" que pudieron participar en la formación a los "nuevos dogmáticos" durante las décadas siguientes. ${ }^{65}$

influido significativamente en Labatut, sino también, en menor medida, en algunos de los futuros miembros de la aquí denominada "Nueva Dogmática Chilena" de la década de 1960: Luis Ortiz, Sergio Politoff y Alfredo Etcheberry (los dos primeros estudiaron un Diploma de Postgrado en Roma), a pesar de que en ellos el influjo de la dogmática alemana ya se había asentado.

59 JIMÉNEZ DE ASÚA, Luis, El Criminalista, $2^{a}$ Serie, T. III, Buenos Aires: Zavala Ed., 1960, p. 104. En todo caso, donde se completa el abandono del positivismo es en la siguiente edición: Manual de Derecho penal, T. I., 3a ed., Santiago: Ed. Jurídica de Chile, 1958.

${ }^{60}$ ALESSANDRI, Arturo, "Revista de Ciencias Penales", Revista de Ciencias Penales, T.I (1935), p. 3.

${ }^{61}$ Sobre la Reforma de 1933, véase BAEZA M., Mario, Esquema y notas para una historia de la Facultad de Ciencias Jurídicas y Sociales de la Universidad de Chile, Santiago: Tesis UCh, 1944, p. 222.

${ }^{62}$ Anales de la Facultad de Ciencias Jurídicas y Sociales, Vol. III (1937), Nos. 9 y 10, pp. 101 y ss.

${ }^{63}$ Según los Anales de la Facultad de Ciencias Jurídicas y Sociales, Cuarta Época, Vol. VIII (1967), No 7, pp. 151-156, entre 1935 y 1960 se habían incorporado también como Profesores de Derecho Penal al Seminario don Rodolfo González Morales (1936) y don Benjamín Melo Freedman (1951), cuyo rastro bibliográfico no he podido reconstruir.

${ }^{64}$ Anales de la Facultad de Ciencias Jurídicas y Sociales, Cuarta Época, Vol. VIII (1967), No 7, "lista de profesores", pp. 151-156. Sobre Pedro Silva Fernández, como dogmático, véase la nota al pie no 11.

${ }^{65}$ Significativo es el caso de Sergio Politoff, quien no obstante haber realizado su Memoria bajo la dirección de Álvaro Bunster, reconoce en la nota necrológica sobre Gustavo Labatut su carácter de "maestro", que le permitió no "envejecer" en la cátedra y, al contrario, acoger y favorecer "con modestia excepcional la inquietud de nuevos espíritus, seducidos por el rigor del método jurídico y la urgencia de la reconstrucción dogmática de nuestra ley" (POLITOFF, Sergio, "Gustavo Labatut Glena (1896-1963)", Revista de Ciencias Penales, T. XXII (1963), p. 166). Esto se demuestra, entre otras cosas, por la realización, a partir de la década de 1940 de numerosas memorias de prueba sobre aspectos dogmáticos, como las de: BALliviAN H., José, El delito de apropiación indebida (art. $470 N^{o} 1$ del Código penal), Tesis UCh, Santiago: La Gratitud, 1937; ORREGO V., Germán, Delitos de imprenta o de publicación, Tesis UCh, Santiago, 1937; CABRERA B., Gonzalo, Del concepto jurídico de delito, Tesis UCh, Santiago: Leblanc, 1941; CORNEJO L., Hernán, La responsabilidad cuasidelictual del médico, Tesis UCh, Santiago: Talleres Gráficos Valdés Hermanos, 1945; FUENTES Z., Myrtha, Cuasidelito penal, Tesis UCh, Santiago: Imp. Fuentealba, 1946. En los Anales de la Facultad de Ciencias Jurídicas y Sociales, Vol. XIII (1948-1949), Nº 52-59, pp. 85 y ss., el año 1948, aparecen 18 memorias de prueba relativas al Derecho penal. En la sede de Santiago, el número total de memorias de penal de ese año fue de 15, de entre las cuales pueden destacarse las de Álvaro Bunster, que analizaremos a continuación, y René PICA URRUTIA, Desarrollo práctico de las reglas para la aplicación de las penal, según las atenuantes y agravantes que concurran o falten (Código Penal y Ley N. ${ }^{\circ}$ 6,026, sobre Seguridad Interior del Estado, con las modificaciones que le introdujo la, Ley N. ${ }^{\circ}$ 8,987, sobre Defensa de la Democracia), Tesis UCh, Santiago: IMP de Carabineros, 1948. La mayor parte del resto corresponden a colecciones de jurisprudencia (muy abundantes a partir de 1945) sobre diversos temas de parte especial y general. Ese 
Así, para el año 1950, ya se habían formado al alero de Labatut y M. Schweitzer S., dejando de lado el estilo autodidacta anterior, y realizando memorias de prueba en la materia, Eduardo Novoa Monreal (1939) ${ }^{66}$ y Álvaro Bunster Briceño (1948), ${ }^{67}$ quien, como veremos más adelante, sería, a su vez, el formador de buena parte de la Nueva Dogmática Chilena.

Sin embargo, el Seminario padeció durante sus primeras décadas de existencia de falta de recursos bibliográficos, al punto que en el prólogo de la Memoria de Alfredo Etcheberry, del año 1955, el mencionado Álvaro Bunster habla de "la indigencia bibliográfica que padecemos". 68

1.3.2. La influencia de los primeros dogmáticos chilenos en la Revista de Ciencias Penales y en el Instituto de Ciencias Penales de Chile

Según se lee en las primeras páginas del número inicial de la Revista de Ciencias Penales, aparecido el año 1935, ella surge "bajo los auspicios" del recién creado Seminario de Derecho Penal y Medicina Legal de la Universidad de Chile, ${ }^{69}$ pero por "la iniciativa" de la Dirección General de Prisiones, ${ }^{70}$ bajo cuya "Dirección y Administración" se editaron los primeros tres Volúmenes (1935 a 1937).

Su primitiva orientación positivista aparece claramente en esta presentación: El Decano de la Facultad de Derecho da por "reemplazado" el "concepto meramente objetivo del delito", afirmando que "a la Ciencia Penal" de la época "ya no le interesa el delito en cuanto institución jurídica, le interesa el delincuente, a quien es menester corregir y encauzar por la senda del bien", la cual, a pesar de ser "conocida en Chile" y "ampliamente difundida por nuestros profesores universitarios", no se habría divulgado

año se aprobó también, en la sede de Valparaíso, la Memoria de Waldo del VILLAR Brito, sobre el tema de la Malversación de caudales públicos (Tesis UCh, Valparaíso, Imp. Dir. Gral. De Prisiones, 1948), quien luego se convertiría en Profesor de Derecho penal de dicha Sede y posterior Facultad autónoma.

${ }^{66}$ NOVOA M., Eduardo, Teoría del Consentimiento de la Víctima del Delito, Tesis UCh, Santiago: Talleres Gráficos La Nación, 1939.

${ }^{67}$ BUNSTER B., Álvaro, La malversación de caudales públicos. Estudio de doctrina y jurisprudencia, Tesis UCh, Santiago: 1948, pp. III-VI.

${ }^{68}$ ETCHEBERRY, Alfredo, El concurso aparente de leyes penales, Santiago: Ed. Jurídica, ca. 1955, p. xi. Con ser cierto el aserto, referido a obras originales en alemán (cuya extensa bibliografía hace pequeño cualquier esfuerzo por adquirir una parte de ella) o inglés y, sobre todo, a las Revistas; hay que decir que, al menos en 1940, ya se disponía en la Biblioteca de la Facultad no sólo de obras de Garófalo y Ferri, sino también de Carrara y, sobre todo, de las entonces existentes traducciones de los Tratados de v. Liszt, Merkel y Mezger, y de buena parte de las obras de Jiménez de Asúa aparecidas hasta ese momento (UNIVERSIDAD DE CHILE, Catálogo de la Biblioteca de Ciencias Jurídicas y Sociales, Santiago: Imp. Dir. Gral. de Prisiones, 1940, pp.105-114). Además, hay constancia que ya en 1956 se recibía en la Biblioteca al menos el Anuario de Derecho Penal y Ciencias Penales de España (Anales de la Facultad de Ciencias Jurídicas y Sociales, Tercera Época, Vol. III (1956), No 5, p. 289, aunque ese año sólo ingresaron "memorias de prueba" del área (p. 282s), lo que da cuenta de una inexistente política de adquisiciones al respeto. Muy posteriormente, en el año 1966, se menciona en la Memoria del Seminario la recepción de una donación de "78 libros de Filosofía del Derecho y Derecho Penal" que hizo el 7 de diciembre de 1966 la Embajada alemana, agregando que "la Biblioteca del Seminario alcanza con ella los 2.000 ejemplares" (Anales de la Facultad de Ciencias Jurídicas y Sociales, Cuarta Época, Vol. VI (1966), № 6, pp. 137 y ss.). Para notar la magnitud del cambio ocurrido entre la década de 1940 y el año 1965 en cuanto a material bibliográfico, baste señalar que en el Catálogo de 1937, las obras de Penal, Procesal Penal y Medicina Legal sumaban alrededor de 350 ejemplares (Anales de la Facultad de Ciencias Jurídicas y Sociales, Vol. III (1937), Nº 11 y 12, pp. 287-301).

${ }^{69}$ ALESSANDRI, "Revista", cit. nota al pie no 60, p. 3.

70 "Revista de Ciencias Penales", Revista de Ciencias Penales, Vol. I (1937), No 1, p.1. 
Polit. crim. Vol. 6, № 11 (Julio 2011), Art. 3, pp. 44 - 105.

[http://www.politicacriminal.cl/Vol_06/n_11/Vol6N11A3.pdf]

en "una publicación adecuada". Y le atribuye, entonces, a la Revista de Ciencias Penales, realizar esa finalidad: "dar a conocer los modernos principios de la Ciencia Penal". ${ }^{71}$ Por su parte, a nombre de la Dirección General de Prisiones, se propone un plan más "ecléctico" si se quiere, al afirmar únicamente que la Revista proporcionará

"a los abogados criminalistas y a los estudiosos de las ciencias que dicen relación con la criminalidad, los elementos que el diario estudio requiere. Los artículos de índole técnica o doctrinaria; la jurisprudencia penal; la estadística carcelaria; la legislación punitiva o preventiva con sus antecedentes o comentarios". ${ }^{72}$

La original tendencia positivista criminológica de la Revista de Ciencias Penales se explica no sólo por las palabras antes transcritas, sino también porque, en los hechos, su "Dirección y Administración" se radicaba en la Dirección General de Prisiones, cuyo entonces Director General, Manuel Jara Cristi, no ocultaba su obvio interés criminológico, atendida la función que desempeñaba. ${ }^{73}$ Así, predominaron en su "Primera Época" (1935-1938, T. I a IV) los textos de tendencia positivista criminológica, pero también hubo en ese período importantes textos de corte dogmático, de autores como Pedro Ortiz Muñoz y Rafael Fontecilla, que ya hemos reseñado. Además, el primer Director de la Revista, según aparece en la portada del único Volumen aparecido el año 1938 (Año IV, T. IV, No s 18-19-20), el abogado Abraham Drapkin, tendía en aquella época más hacia el cultivo de la "técnica jurídica" que a la criminalística $^{74}$ (y por eso Jiménez de Asúa lo consideraba entre quienes estudiaban en Chile la verdadera "teoría jurídica del delito"). ${ }^{75}$

La "Segunda Época" de la Revista de Ciencias Penales está ligada a la creación y fortalecimiento del Instituto de Ciencias Penales, que asume como entidad Editora.Y es un hecho que, al contrario del predominio de los artículos de corte positivista criminológico de su "Primera Época", a partir del primer tomo de su "Segunda Época" (T. V, 1941), la mayor parte de sus artículos serían de corte técnico o dogmático. ${ }^{76} \mathrm{Y}$ también lo serían sus Directores, salvo el interregno entre 1942 y 1943, en que asumió la dirección el médico cirujano Luis Urrutia. En efecto, Abraham Drapkin dirigió la Revista hasta 1946, con el intervalo ya señalado. Luego le sucedió por un muy breve tiempo, Pedro Ortiz Muñoz, quien falleció en 1947, año en que, por lo mismo, el volumen respectivo no se editó, dando así origen a una nueva "Época" de la Revista, que comenzó en 1948, bajo la dirección del abogado Tomás Chadwick (T. X), para pasar posteriormente a la del magistrado Enrique Schepeler, en su T. XII (1950) y, finalmente viene a quedar en manos de Álvaro Bunster, quien la dirigió desde 1952 hasta 1960 (T. XIX). El año 1961 (T. XX), su Director pasa a ser Alfredo Etcheberry

\footnotetext{
71 Ídem.

72 "Revista Ciencias Penales", cit. nota al pie n 70.

${ }^{73}$ En esta calidad asiste al Primero Congreso de Criminología realizado en Buenos Aires, en 1938 (Revista de Ciencias Penales, T. IV (1938), p. 251.

${ }_{74}$ Abraham DRAPKIN derivó de los estudios propiamente "jurídicos" citados en la nota al pie $\mathrm{N}^{\mathrm{o}} 11$, hacia la investigación criminológica de campo, como puede verse en sus "Apuntes para la formación del vocabulario del hampa chilena". Revista de Ciencias Penales, T. IV, 1938, p. 484-492. Sin embargo, nunca perdió el interés por la "técnica jurídica", como se aprecia en su texto autónomo Relación de causalidad y delito. Santiago: Cruz del Sur, 1943, 114 p. Abraham Drapkin era hermano del entonces Director del Instituto Nacional de Clasificación y Criminología, dependiente de la Dirección General de Prisiones (editora de la Revista), don Israel Drapkin, propiamente criminólogo.

${ }^{75}$ Ver nota al pie $\mathrm{n}^{\mathrm{o}} 11$.

${ }^{76}$ Véase MATUS, "Positivismo", cit. nota al pie $n^{\circ} 9$, pp.186-188, y los textos citados en la nota al pie $\mathrm{N}^{\mathrm{o}} 30$.
} 


\section{MATUS, Jean Pierre "Origen, consolidación y vigencia de la}

Nueva Dogmática Chilena (ca. 1955 1970)"

O., uno de los "discípulos" de Bunster, como veremos más adelante, dando así paso al relevo generacional de la década de 1960 y al predominio de la Nueva Dogmática Chilena en la discusión y enseñanza del Derecho penal en Chile.

La Revista sirvió de este modo para "preparar" el terreno en que se desarrollaría la Nueva Dogmática Chilena, siendo considerada por Jiménez de Asúa como "una de las más prestigiosas de Hispanoamérica", con un solo defecto: su "irregularidad lamentable". ${ }^{77}$

Un proceso similar de "preparación" del ambiente para el florecimiento de la Nueva Dogmática Chilena en la década de 1960 se produjo al interior del Instituto de Ciencias Penales de Chile, que rápidamente se transformó desde un centro de carácter primordialmente positivista criminológico a uno de discusión dogmática gracias al predominio que, entre sus miembros, alcanzaron los primeros dogmáticos chilenos.

En efecto, según se lee en el T. III de la Revista de Ciencias Penales, la historia de la creación del Instituto de Ciencias Penales fue la siguiente:

"A iniciativa del Director General de Prisiones, don Manuel Jara Cristi, y del Director del Instituto Nacional de Clasificación y Criminología, doctor Israel Drapkin, un grupo de figuras descollantes de la magistratura, la Universidad, la administración, el foro, la enseñanza y la profesión médica,dieron nacimiento a esta asociación cuyos fines [...] pueden concretarse en el estudio del complejo conjunto de disciplinas que dicen relación con el hombre delincuente y sus acciones o estados antisociales, a propulsar la reforma y progreso de los institutos

\footnotetext{
${ }^{77}$ JIMÉNEZ DE ASÚA, Luis, El Criminalista III ( $2^{a}$ S.), cit. nota al pie n ${ }^{\circ} 59$, pp. 104 y ss. En este lugar, se comenta el contenido del volumen del segundo semestre del año 1953, aparecido en 1954. Para Jiménez de Asúa, esta irregularidad carece de explicación, pues "en Chile, por la calidad de sus penalistas, se debería trabajar más y producir en escala mucho mayor" (El Criminalista, $2^{a}$ Serie, T. I, Buenos Aires: Zavala, 1955, p. 71). La irregularidad de la Revista se debía, a mi juicio, a tres factores: a) su excesiva pretensión original de "bimestralidad", difícil de cumplir; b) el ejercicio profesional de sus Directores y miembros del cuerpo editorial: en la época, no existían profesores de jornada completa o media jornada que pudiesen hacerse cargo de una tarea constante, y por lo tanto, sus Directores y cuerpo editorial dedicaban la mayor parte de su tiempo al ejercicio de la profesión de abogado; c) la falta de financiamiento, provocada por el alejamiento de Manuel Jara Cristi de la Dirección General de Prisiones, como lo deja entrever el Director en la presentación del $\mathrm{N}^{\circ} 1$ del $\mathrm{T}$. V, donde comienza la "Segunda Época". Para apreciar la irregularidad de la Revista, baste señalar que ya el T. II contenía números "fusionados" (el 6-7 y el 10-11), lo que cambió, de hecho, la periodicidad inicial ("bimestral") a "trimestral". Y en el T. IV (1938) se fusionaron tres números en un Volumen ( $\mathrm{N}^{\circ} \mathrm{s} 19,21$ y 21), apareciendo ahora sólo dos números al año (ese "fusionado" y el $\mathrm{N}^{\mathrm{o}} 22$ ). La periodicidad se transforma así, en realidad, en semestral. Luego la publicación se paralizó hasta 1941. Desde 1941 a 1960, que es el período que aquí interesa, la publicación perdió toda periodicidad: sólo los T. VI a IX (1943-1946) mantuvieron cierta regularidad con cuatro números cada año. Pero antes, en el T. V, se había fusionado en cuatro números la producción de dos años (1941 y 1942). Después, no aparece el tomo correspondiente al año 1947. El de 1950 (T. XII), aparece en un único Volumen. Lo mismo sucede con el T. XIV, que aparece no dos, sino cuatro años después (1954). Sólo en los Tomos XV a XIX (1955-1960) se retoma una cierta regularidad, ahora con una pretensión más bien de carácter "semestral", pero con un gran atraso en la impresión. La explicación de esta irregularidad es atribuida por Álvaro Bunster al presentar la "Tercera Época" que así se iniciaba a "dificultades de orden económico" que, a partir de ese momento, se superaban gracias a la intervención de la Editorial Jurídica de Chile (Revista de Ciencias Penales, T. XV (1956, p. 3). Nótese, además, que no bien iniciada la "Tercera Época" de la Revista, entra en vigor de la Ley $\mathrm{N}^{0}$ 12.265, de 24 de octubre de 1956, que otorgó recursos y autonomía financiera al Instituto de Ciencias Penales.
} 
Polit. crim. Vol. 6, № 11 (Julio 2011), Art. 3, pp. 44 - 105.

[http://www.politicacriminal.cl/Vol_06/n_11/Vol6N11A3.pdf]

penales que recoge nuestra legislación, y a señalar aquellos que deben ser incorporados en ella". ${ }^{78}$

Dado lo anterior, no es de extrañar que el primer Directorio del Instituto haya sido Presidido por Raimundo del Río y que entre sus miembros se contasen el mentado Israel Drapkin y el doctor Fernando Allende Navarro. También formaban parte de este primer Directorio el Profesor de Derecho Penal Valentín Brandau, quien podría considerarse un "exégeta" o "clásico"a la italiana, enfrentado desde una concepción moralista del Derecho al positivismo criminológico, pero no un técnico-jurídico o dogmático; ${ }^{79}$ y los propiamente precursores de la dogmática en Chile, Pedro Ortiz Muñoz y Daniel Schweitzer S. Raimundo del Río presidió el Instituto hasta 1941, siendo reemplazado en el cargo por Luis Cousiño Mac Iver, quien permaneció en la presidencia hasta 1953. Es significativo que en este período Pedro Ortiz Muñoz haya accedido a la Vicepresidencia del Instituto, cargo que detentaba a la fecha de su muerte, en 1947. A partir de Mac Iver, nunca más la Dirección del Instituto dejaría de estar en manos de los "dogmáticos". En efecto, en 1953 le sucedió Daniel Schweitzer S., ${ }^{80}$ quien ejercería la presidencia hasta 1959, año en que le sucede Eduardo Novoa Monreal (1959-1970). En el período de Daniel Schweitzer S., el Instituto aparece fuertemente ligado a la Universidad, al punto que sus memorias son integradas a los Anales de la Facultad. Allí se puede leer cómo en 1956 obtiene el Instituto la dictación de una Ley Especial, la $\mathrm{N}^{\mathrm{o}} 12.265$, de 24 de octubre de ese año, que le otorga autonomía financiera y recursos provenientes de la venta en remate de los objetos decomisados y no reclamados, los cuales le permitieron adquirir "un local apropiado", con salas de clases, conferencias, secretaría y biblioteca pública. ${ }^{81}$ Este local se ubicó, primero, en Ahumada 141, y se trasladó, definitivamente, al Edificio Pacífico de la calle Huérfanos $N^{0} 1147$, Of. 546, el año $1965 .{ }^{82} \mathrm{Su}$ instalación y dotación bibliográfica permitieron a los "jóvenes" de 1960 tener no sólo un lugar de reunión y discusión, sino, sobre todo, el acceso a fuentes de las que los primeros dogmáticos carecían, incluyendo no sólo la reciente producción iberoamericana, especialmente argentina y española, sino también la nueva literatura en alemán, italiano y francés. ${ }^{83}$

\footnotetext{
${ }^{78}$ Revista de Ciencias Penales, T. III, Nos 14-15 (1937), p. 281. Los Estatutos del Instituto y su primer Directorio se transcriben en las páginas siguientes.

${ }^{79} \mathrm{Su}$ rechazo a las ideas de Garófalo y su concepto de delito, alejado de la teoría jurídica o dogmática, así lo refleja: "es delito todo acto inmoral que perturba o quebranta las condiciones estrictamente fundamentales de la vida social y que no es ni puede ser tolerado por la colectividad, sino, por el contrario, necesariamente reprobado y castigado por ella" (BRANDAU, Valentín, "Introducción al estudio del Derecho penal”, Revista de Ciencias Penales, T.I (1935), pp. 122-135, 302-317, 498-503, p. 500.

${ }^{80}$ Sobre Daniel Schweitzer S., como "dogmático", véase la nota al pie $\mathrm{n}^{\circ} 11$ y el texto a que hace referencia.

${ }^{81}$ Los Informes del Instituto de Ciencias Penales emitidos a la Facultad de Ciencias Jurídicas de la Universidad de Chile entre 1952 y 1957 se encuentran en los respectivos Anales, Tercera Época, Vol. I (1952-1954), Nos 1-3, p. 229; Vol. II (1955), No 4, p. 244; y Vol. IV (1957), Nº 6, p. 156.

${ }^{82}$ Instituto de Ciencias Penales, "Memoria de las actividades realizadas entre los meses de abril de 1967 y marzo de 1968", Revista de Ciencias Penales, T. XXV (1966), pp. 69-73, p. 70.

${ }^{83}$ Actualmente, la Ley que permitía el financiamiento del Instituto ha dejado de producir recursos, debido a la entrada en vigor del nuevo sistema procesal penal, lo que ha ocasionado que las oficinas del Instituto están cerradas, funcionando su Biblioteca como anexa a la del Centro de Estudios de Derecho Penal de la Universidad de Talca, en su Campus Santiago (ver: http://www.dpenal.cl).
} 


\section{Las condiciones para el florecimiento de la Nueva Dogmática Chilena}

\subsection{La segunda generación de dogmáticos chilenos: Eduardo Novoa Monreal y Álvaro Bunster (ca. 1940 1955) y el fin de la formación "autodidacta" de los penalistas chilenos}

La característica principal de esta generación, ya anunciada, es que sus principales figuras realizaron su Memoria de Prueba bajo la dirección de un profesor de Derecho penal y en un ambiente en que, como vimos, ya empezaba a predominar, bajo el influjo de Jiménez de Asúa, el "sistema neoclásico" alemán como esquema de análisis del delito. Sus principales figuras, Eduardo Novoa Monreal y Álvaro Bunster Briceño, lo adoptan para sus clases y primeras contribuciones escritas, con plena legitimidad y sin necesidad ya de tener que discutir sus fundamentos con los positivistas criminológicos. La denominada "Lucha de Escuelas" es, para ellos, en tanto académicos, de hecho, un asunto de carácter histórico, a pesar de que todavía positivistas como Del Río están vivos y dictan cátedra. En cambio, comienza a despuntar en ellos la disputa entre los sistemas "neoclásico" y "finalista".

Coetáneo a ellos fue Julio Zenteno Vargas quien, sin embargo, se encuentra ligado a la escuela técnico-jurídica italiana, como ayudante y discípulo de Gustavo Labatut, cuyo manual actualizó desde su muerte y hasta $1990 .{ }^{84}$ Al igual que Labatut, Zenteno ejerció largo tiempo la docencia en la Universidad de Chile, primero como "Jefe de Trabajos" del Seminario (1953), y luego como su Subdirector y Director subrogante (1965), hasta su conversión en Departamento de Ciencias Penales, el año 1970, años en que se aumentaron los fondos bibliográficos de la Universidad y se dio entrada a la misma a los miembros de la Nueva Dogmática Chilena. ${ }^{85}$

\footnotetext{
${ }^{84}$ En efecto, su memoria de prueba trató Del régimen de la propiedad austral y de la prescripción de corto tiempo regida por el decreto con fuerza de ley $N^{\circ} 260$ (Tesis UCh, 1941), y, salvo su artículo más bien de difusión titulado "La comunidad y el Terrorismo" (Revista Temas de Derecho, Año IV, No 1 (1989), p.26-28), no encontré otros textos de la especialidad a su nombre. La última actualización de la obra de Labatut es de 1990 (LABATUT G., Gustavo, Derecho penal, $9^{a}$ Ed. actualizada por Julio ZENTENO Vargas, Santiago: Ed. Jurídica de Chile, 1990, 2 Vols., Vol. 1: parte general; Vol. 2: parte especial). Otros antecedentes profesionales de Zenteno, fallecido el año 2003, incluyendo su participación en las "Comisiones Legislativas" de la Dictadura Militar (1973-1990), pueden verse en SCHWEITZER W., Nullum crimen, cit. nota al pie $\mathrm{n}^{\circ} 11$, pp. 19 y ss.

${ }^{85}$ Anales de la Facultad de Ciencias Jurídicas y Sociales, Tercera Época, Vol. I (1952-1954), №s 1-3, p. 239. En los Anales de la Facultad de Ciencias Jurídicas y Sociales, Cuarta Época, Vol. VII (1967), ํ7, p. 239, se señala su fecha de ingreso a la Facultad: 2 de enero de 1953. Dado que esta es la fecha del Decreto de nombramiento, no es inverosímil pensar que su ingreso efectivo al trabajo del Seminario haya sido durante el año 1952. Zenteno fue nombrado Profesor de Derecho Penal "Ordinario", el año 1966 (Anales de la Facultad de Derecho, Cuarta Época, Vol. VI, No 6 (1966), p. 117s.). En calidad de subrogante (como hemos dicho, tenía nombramiento de "Subdirector"), ejerció de hecho como Director del Seminario desde el año 1965 hasta su reemplazo en 1970 por el Departamento de Ciencias Penales y Criminología. Ello no le impidió firmar directamente como "Director" del Seminario, sin más, las respectivas Memorias de 1965 en adelante, como puede verse en los números de los Anales de la Facultad de Derecho, Cuarta Época, correspondientes a 1965 (Vol. V, años 1964-1965, No 4, p. 162), 1966 (Vol. VI, N 6, p. 138, donde, además, se da cuenta de la "Comisión" del "Director" a Estados Unidos, Álvaro Bunster, la que se prolongaría por casi dos años) y 1967 (Vol. VII, № 7, p. 241), aunque en la misma publicación, figura en los años 1966 y 1967 como "Director del Departamento de Derecho Penal y Medicina Legal" don Wenceslao Olate Cerda (Vol. VI, No 6, p. 121, y Vol. VII, No 7, p. 151). En estas memorias puede verse el progreso del Departamento en materiales bibliográficos y personal durante la época. El reemplazo del Seminario por el Departamento fue producto del proceso de reforma universitaria de ese entonces y dio lugar a una elección desarrollada el 16 de junio de 1970, en que resultó electo Director, Álvaro Bunster (Anales de la Facultad de Derecho, Cuarta Época, Vol. XI (1970), N ${ }^{\circ}$ 11, p. 21). En esta elección resultaron electos "Consejeros Académicos" del Departamento, los profesores
} 
Polit. crim. Vol. 6, № 11 (Julio 2011), Art. 3, pp. 44 - 105.

[http://www.politicacriminal.cl/Vol_06/n_11/Vol6N11A3.pdf]

\subsubsection{Eduardo Novoa Monreal y su versión rigorosa del "sistema neoclásico"}

Eduardo Novoa Monreal asistió al curso de Derecho penal en la Universidad de Chile que dictaba Raimundo del Río, sin embargo, realizó su Memoria de prueba al alero de Miguel Schweitzer S. y Gustavo Labatut ${ }^{86}$ y se declara un discípulo de Pedro Ortiz Muñoz. ${ }^{87}$ No obstante, no asumió como Profesor de Derecho Penal en el Seminario de la Universidad de Chile sino hasta fines de la década de $1950,{ }^{88}$ tras una larga trayectoria como abogado y ayudante y Profesor del mismo ramo en la Universidad Católica de Chile (desde 1948). Durante la década de 1960, junto con su cada vez mayor compromiso en la actividad política, ${ }^{89}$ derivó sus intereses desde el Derecho penal a la Filosofía, asumiendo la Cátedra de Teoría General del Derecho entre 1970 y

de Derecho Penal Luis Cousiño, Julio Zenteno, Francisco Grisolía, Jaime Vivanco y Luis Ortiz, además de la criminóloga Loreto Hocker). Bunster no asumió el cargo por su designación en el Gobierno de la Unidad Popular como Embajador en el Reino Unido, asumiendo la subrogancia Juan Bustos.

${ }^{86}$ Véanse los Informes respectivos en NOVOA M., Eduardo, Teoría, cit. nota al pie n ${ }^{\circ} 66$.

${ }^{87}$ Ver nota al pie ${ }^{\circ} 19$.

${ }^{88}$ Usualmente se afirma que NOVOA habría obtenido el Título de Profesor Extraordinario de Derecho Penal en la Universidad de Chile el año 1952, con su texto Los elementos del delito. Explicación elemental sobre su estructuración sistemática en el concepto jurídico-penal, Santiago: apartado de los $<<$ Anales Jurídico-sociales>> (Universidad Católica de Chile), Año XXXVII, Número Noveno, 1952 (Así, por ejemplo, BERGALLI, Roberto, "Una ética absoluta y vital. Eduardo Novoa Monreal (19162006)", en VILLEGAS, Myrna (Coord.), Contribuciones críticas al sistema penal de la post modernidad, in memoriam a Eduardo Novoa Monreal, Santiago: U. Central, 2007, pp. 11-18, p. 13. Publicado antes en Nueva Doctrina Penal, 2006/A, disponible en Internet en www.pensamientopenal.com.ar/ndp/41bergalli.pdf [visitado el 1.3.2011]). Sin embargo, ello no parece que significó inmediatamente asumir una Cátedra en dicha Facultad, pues en los Anales de la Facultad de Ciencias Jurídicas y Sociales, Cuarta Época, Vol. VIII (1967), No 7, pp. 151-156, "Lista de Profesores", figura como fecha de ingreso a la Universidad el año 1960. Mi interpretación es que Novoa habría obtenido en 1952 el "Título" de Profesor Extraordinario de la Facultad de Derecho de la Universidad de Universidad de Chile, pero no habría empezado a realizar clases en forma, como miembro del cuerpo docente de la Facultad, sino hasta alguna fecha cercana a la que mencionan los Anales como de "ingreso" (de hecho, en los Anales del año 1958, figura Eduardo Novoa a cargo de un curso de postgrados en La Serena, Anales de la Facultad de Ciencias Jurídicas y Sociales, Cuarta Época, Vol. II (1958-1959), N², p. 168; y en una referencia a un Congreso realizado en 1961, se le menciona expresamente como "profesor extraordinario", Anales de la Facultad de Ciencias Jurídicas y Sociales, Cuarta Época, Vol. III (1961-1963), $\mathrm{N}^{\mathrm{o}} 3$, p. 115). El hecho de que recién en 1964 figurara en los Anales expresamente su designación como Profesor Extraordinario ese año, parece explicarse por el proceso de renovación de plantas iniciado, precisamente, ese año (Anales de la Facultad de Ciencias Jurídicas y Sociales, Cuarta Época, Vol. IV(1964-1965), № 4, p. 79).

${ }^{89}$ Lo que lo llevó, por ejemplo, a encabezar una Asamblea que votó la "Censura", en marzo de 1969, del entonces Decano de la Facultad, Eugenio Velasco. Al rechazar esta "Censura”, el Decano cita a NOVOA como afirmando que "la vía para el cambio es la revolución", y que "la universidad es una de las metas para lograr la revolución total de Chile", calificándolo, junto al resto de los censurantes, como un grupo de "extremistas que solo quieren utilizar [la Facultad] con fines políticos" (Anales de la Facultad de Ciencias Jurídicas y Sociales, Cuarta Época, Vol. IX (1969), № 9, p. 119-122). La acusación del Decano, en cuanto al propósito de NOVOA de transformar revolucionariamente la Universidad, no estaba lejos de la realidad, como puede verse en la propuesta que NOVOA redactó la propuesta de la izquierda para la "Declaración de Principios" de la Comisión Central de Reforma del año 1968, donde se lee: "La alternativa revolucionaria constituye para Chile, al igual que para el resto de América Latina, el camino que habrá de remover la sociedad actual, crear la nueva y justa que ha de reemplazarla y construir al hombre nuevo [...] En este compromiso, entendemos la Universidad Nacional reformada como profundamente revolucionaria y como la conciencia critica de los problemas económicos, sociales y culturales del país. A ella le corresponde poner al descubierto la explotación, la miseria y los mecanismos de enajenación de la cultura, y ser factor dinámico y radicalizador de los cambios sociales" (cit. en AGÜERO, Felipe, La reforma en la Universidad de Chile, T. III, Santiago: Eds. Sur, 1987, pp. 55 y ss., donde puede verse una visión de conjunto de este proceso, con especial énfasis en la progresiva polarización y politización del mismo). 


\section{MATUS, Jean Pierre "Origen, consolidación y vigencia de la Nueva Dogmática Chilena (ca. 1955 1970)"}

1972. ${ }^{90}$ El Golpe de Estado de 1973 lo sorprende realizando servicios diplomáticos para la República en el extranjero, encontrándose en Francia en defensa de la Nacionalización del Cobre. A partir de ese momento comienza su exilio, el que se prolongaría hasta 1987. Sin embargo, Novoa no regresaría a la Facultad, y sus últimos años los dedicaría infructuosamente a obtener la anulación del Decreto que lo exoneró de ella, tras la intervención militar de la Universidad, en $1973 .{ }^{91}$

En cuanto a su productividad científica, Novoa fue un autor prolífico: entre 1944 y 1973 no sólo publicó un par de importantes obras generales (los Elementos del delito, en $1952{ }^{92}$ y su Curso de Derecho Penal, en $1960^{93}$ ), sino más de una docena de artículos en la Revista de Ciencias Penales y en otras publicaciones universitarias, sobre variados temas, entre los cuales cabe destacar, por no encontrarse la temática desarrollada en las obras generales, "La obligación jurídica del secreto profesional", "E4 "El delito de homicidio y la intención de matar", ${ }^{95}$ "El concepto de abusos deshonestos", ${ }^{96}$ "Cuestiones jurídicas relativas al delito de amenazas", ${ }^{97}$ y "La legislación penal económica"; 98 así como una monografía acerca del, en 1969, novedoso problema del "trasplante de corazón". ${ }^{99}$ Posteriormente, durante su exilio y tras su retorno a Chile en 1987 aparecieron muchas otras obras de su autoría, enfocadas la mayor parte de ellas en la exposición y defensa de su actuación pública durante el gobierno de la Unidad Popular, ${ }^{100}$ con varias notables excepciones en que sigue apareciendo el dogmático, como su texto sobre los delitos de omisión ${ }^{101} \mathrm{y}$ el referido a la discusión entre Causalismo y finalismo en Derecho penal. ${ }^{102}$

\footnotetext{
${ }^{90}$ De hecho, ya en 1970 aparece como miembro del recientemente creado Departamento de Ciencias del Derecho, a cuya dirección postula, sin éxito (Anales de la Facultad de Ciencias Jurídicas y Sociales, Cuarta Época, Vol. XI (1970), No 11, p. 20.

${ }^{91}$ GUERRA G., Beatriz, Eduardo Novoa Monreal: Vida, obra e influencia dogmática en el derecho penal actual, Tesis UTal, Talca: 2005 (Dir. J.P. MATUS), pp. 3-9, donde pueden consultarse mayores antecedentes y detalles sobre la vida profesional de Novoa. Sobre su exilio, véase especialmente el texto de BERGALLI, "Ética", cit. nota al pie n 88, pp. 15-18.

${ }^{92}$ Cit. nota al pie $\mathrm{n}^{\mathrm{o}} 88$.

${ }^{93}$ NOVOA Monreal, Eduardo, Curso de Derecho Penal, T. I y II, Santiago: Ed. Jurídica, 1960.

${ }^{94}$ Revista de Derecho y Jurisprudencia, T. XLI (1944), pp. 85-100.

${ }^{95}$ Revista de Ciencias Penales, T. VIII (1945), pp. 183-192.

${ }^{96}$ Revista de Ciencias Penales, T. IX (1946), pp. 291-298.

${ }^{97}$ Revista de Ciencias Penales, T. XII (1950), pp. 15-23.

${ }^{98}$ En: Universidad Católica De Chile, Facultad de Ciencias Jurídicas, Políticas y Sociales, La Nueva Legislación y el Desarrollo Económico de Chile. Ciclo de Conferencias, Julio-Septiembre, 1962, Santiago: Editorial Universidad Católica, 1962, pp. 151-177.

${ }_{99}$ NOVOA Monreal, Eduardo, El trasplante de corazón. Aspectos Médico-Legales, Éticos y Jurídicos, Santiago: Ed. Universitaria, 1969.

${ }^{100}$ La lista completa se encuentra en GUERRA, Eduardo Novoa, cit. nota al pie no 91, pp. 11-14. En esta etapa, cabe destacar su Los resquicios legales. Un ejercicio de lógica jurídica, Santiago: Ed. Bat, 1992, donde se aborda la cuestión política y jurídica envuelta en ellos y se transcriben un par artículos del autor aparecidos en el extranjero sobre las vías legales para llegar al socialismo. Un análisis crítico de esta última etapa en la producción intelectual de Novoa, en la que desarrolla su propia Teoría Crítica del Derecho, puede verse en la Memoria de Prueba de VILLALONGA T., Cristián, Introducción a la política-jurídica en Eduardo Novoa (Desde una teoría crítica del Derecho a la vía legal al socialismo durante la Unidad Popular), Santiago. Tesis PUC, 2003 (Prof. Guía: C. FRONTAURA), especialmente pp. 139-167.

${ }_{101}$ NOVOA Monreal, Eduardo, Fundamentos de los delitos de omisión, Buenos Aires: Depalma, 1984.

${ }^{102}$ NOVOA Monreal, Eduardo, Causalismo y Finalismo en Derecho Penal (Aspectos de la enseñanza penal en Hispanoamérica), San José de Costa Rica: Ed. Juricentro, 1980.
} 
Polit. crim. Vol. 6, № 11 (Julio 2011), Art. 3, pp. 44 - 105.

[http://www.politicacriminal.cl/Vol_06/n_11/Vol6N11A3.pdf]

En cuanto a la sistemática de la Teoría del Delito, Novoa presenta la suya por primera vez en su texto Los elementos del delito, aparecido en 1952, "exclusivamente guiado por necesidades pedagógicas" y "dentro de un afán de simplificar los conceptos", reconociendo, de antemano no creer "que haya nada de original en este intento." En efecto, Novoa recoge aquí una versión rigurosa del "sistema neoclásico", explícitamente tributaria del modelo "clásico" de Pedro Ortiz, pero, al mismo tiempo, acorde con las variaciones experimentadas en el período entreguerras, especialmente en cuanto a reconocer elementos normativos y subjetivos en el tipo penal (que, en principio sólo tendría componentes de "carácter objetivo y exento de valoración") y la teoría normativa de la culpabilidad, que denomina "reprochabilidad". En este sentido, se trata de una exposición del sistema "neoclásico" más depurada que la de Bunster, que distingue con claridad los cuatro elementos constitutivos del ("conducta típica, antijurídica y reprochable"), y las relaciones entre ellos, que imponen un orden de análisis "invariable" de los mismos, a saber: "1 ${ }^{\circ}$ Conducta; $2^{\circ}$ Tipicidad; $3^{\circ}$ Antijuricidad y $4^{\circ}$ Reprochabilidad". Al mismo tiempo, se impone una estricta división entre el objeto de valoración (conducta y tipicidad) y su valoración objetiva (antijuricidad), y entre todos ellos y su valoración subjetiva (reprochabilidad), con las consecuentes consecuencias para la participación criminal, según si el hecho es o no "objetivamente" "antijurídico" para todos los partícipes. Por último, el rigor analítico también se impone en el estudio de la "Reprochabilidad", que se propone hacer en tres niveles: imputabilidad, culpabilidad "en sentido estricto" (donde se incluye el dolo y la culpa) y exigibilidad (lo que permite dar entrada a las teoría normativa de la culpabilidad). Rechaza la teoría de la adecuación social y propone un tratamiento separado del error de prohibición frente al error sobre los presupuestos fácticos de una causal de justificación. ${ }^{103}$

Posteriormente, en su Curso de Derecho Penal, aparecido en 1960, no se alteran sino muy marginalmente estas ideas, si bien son profusamente explicadas y desarrolladas: se mantienen los mismos cuatro elementos del delito, pero usa la expresión "culpabilidad" ("en sentido amplio") para referirse al último de ellos, aunque añade que, "apoyándonos en Welzel, preferiríamos denominarlo reprochabilidad", como antes hiciera en los Elementos, definiendo así el delito como "conducta típica, antijurídica y culpable (reprochable)". Los "elementos" del análisis permanecen inalterables en su orden y contenido básico: la "conducta" se define como "puro fenómeno natural", "que consiste en un comportamiento exterior del hombre, positivo o negativo"; la "tipicidad", como la "delimitación" legal de las conductas punibles, que "opera sobre conductas objetivas y se produce mediante fórmulas legales puramente formales y de naturaleza descriptiva", que de manera "anormal" contendrá "elementos normativos" y "descriptivos", y que sólo es "indiciaria" de la "antijuricidad". A su vez, la "antijuricidad", como la "valoración objetiva" de la conducta típica, con las consecuencias antes apuntadas respecto de la participación criminal, pero agregando dos caracteres más: su "realidad" y su "positividad", en el sentido de que no se trata de una valoración meramente formal y de que debe estar presente efectivamente en todo delito, respectivamente. Finalmente, es en cuanto a la "culpabilidad (reprochabilidad)", donde presenta el Curso un desarrollo conceptual mayor que los Elementos, pero manteniendo lo básico ya afirmado: que se trata de un reproche "formulado a quien no se determinó conforme a las pretensiones del Derecho, pudiendo hacerlo" y que sus tres factores constitutivos

${ }^{103}$ NOVOA, Elementos, cit. nota al pie no 88 . Lo entrecomillas en pp. 5-7, 10, 11-12, 19-24 y 56. 
tienen, también, un orden lógico riguroso de análisis: "imputabilidad", “culpabilidad en sentido estricto" (dolo y culpa) y "exigibilidad". ${ }^{104}$

Es en el Curso, donde, además, comienza Novoa a hacerse cargo de la disputa entre el "sistema clásico" y el "finalista", discusión que prolongaría hasta bien entrada la década de 1980, pero sin alterar la línea argumentativa de fondo, basada no en una crítica al concepto final de acción, que acepta, sino principalmente en las desventajas didácticas de la sistemática finalista. ${ }^{105}$

\subsection{2. Álvaro Bunster Briceño y su apertura hacia el "sistema finalista"}

Álvaro Bunster Briceño inició sus estudios de Derecho en la Universidad de Chile el año 1938, donde cursó Derecho penal en la Cátedra de Raimundo del Río. Al egresar, el año 1942, viajó a Brasil, país en el que permaneció durante dos años. De regreso a Chile, realizó su Memoria de prueba, La malversación de caudales públicos, bajo la dirección del profesor Gustavo Labatut Glena, la cual fue presentada y aprobada el año 1948. Inmediatamente después comenzó su carrera docente en la Universidad de Chile en el Seminario dirigido por el Profesor Labatut. Entre los años 1950 y 1951 cursó y obtuvo el Diploma de Especialización en Derecho Penal de la Scuola di Perfezionamento in Diritto Penal de la Universidad de Roma, becado por el gobierno Italiano. El año 1952 obtiene su nombramiento como Profesor de la Facultad. ${ }^{106}$ Desde ese mismo año y hasta 1960 asume la Dirección de la Revista de Ciencias Penales. Entre 1957 y 1969 fue Secretario General de la Universidad de Chile. Al fallecer Gustavo Labatut, asumió la Dirección del Seminario de Derecho Penal y Medicina Legal, la cual ejerció efectivamente sólo entre 1963 y 1965. Durante el año 1966 y principios de 1967 permaneció en Comisión de Estudios en la Universidad de Berkeley, dando paso a la dilatada subrogancia de Julio Zenteno en la Dirección del Seminario. Electo para el cargo de Director del nuevo Departamento de Ciencias Penales y Criminología, el año 1970, no lo ejerce ni tampoco imparte docencia en Chile a partir de 1971, al asumir como Embajador de la República ante el Reino Unido, durante el gobierno de Salvador Allende, cargo en que lo encontró el Golpe de Estado de 1973, con el que comenzó su exilio, del cual no volvería. ${ }^{107}$

\footnotetext{
${ }^{104}$ NOVOA Monreal, Eduardo, Curso de Derecho Penal, T. I, Santiago: Ed. Jurídica, 1960, p 229. Lo entrecomillas en pp. 226-228,265, 311, 334, 443 y 445.

${ }^{105}$ NOVOA, Curso I, cit. nota anterior, p. 229. Veinte años después volvería sobre este asunto en su Causalismo y finalismo, cit. nota al pie $\mathrm{n}^{\circ} 102$, donde señala los siguientes "yerros" y "peligros" que observa en la doctrina finalista: a) malentender el "sistema clásico", que no afirmaría la división de la acción en la realidad, sino sólo una "descomposición intelectual de un concepto difícil y complejo como el delito"; b) que "su concepto excesivamente restricto de acción deja fuera [del ámbito de acción del Derecho penal] a muchos comportamientos humanos que es de verdadera conveniencia dejar adentro"; c) que el concepto de acción final tiene "dificultad para incorporar al hecho culposo dentro de su estricta noción de conducta"; d) que la doctrina de Welzel es "un intento de etización del Derecho penal" al otorgarle la función ética de "proteger los valores elementales de conciencia, de carácter ético-social", lo que tiene "el riesgo de llegar a un Derecho penal de autor"; y e) que "conduce a una prescindencia última del concepto de bien jurídico". Sin embargo, sigue aceptando la idea de que la conducta humana se describe mejor ontológicamente, en los casos de acciones finales, cuando se parte, precisamente, de la teoría de la conducta final. Lo entrecomillado en pp. 57, 74-76, 96, 102, 107 y 144.

${ }^{106}$ Anales de la Facultad de Ciencias Jurídicas y Sociales, Cuarta Época, Vol. VIII (1967), N 7 , "lista de profesores", p. 151-156.

${ }^{107}$ BERNALES, Emmanuel, Álvaro Bunster Briceño: vida, obra e influencia en el Derecho penal actual, Tesis UTal, Talca: 2009 (Dir. J.P. MATUS), p. 4, con más detalles y referencias sobre la vida de Bunster en el exilio (p. 5-7), donde estuvo primero en Cambridge, desde 1974 a 1977, para radicarse finalmente
} 
Calificado en su época por Jiménez de Asúa como "la más henchida esperanza del nuevo penalismo chileno", ${ }^{108}$ por la alta calidad de sus trabajos, éstos, lamentablemente, durante sus años en Chile, fueron escasos: sólo se cuentan su citada Memoria de Prueba de 1948, La Malversación de Caudales Públicos, y dos artículos más: "La voluntad del acto delictivo" 109 y "Finalidad de las penas privativas de libertad". ${ }^{110}$

En efecto, en la Malversación, aunque se trata de un tema de parte especial, se puede apreciar la sistemática adoptada por Bunster (y que suponemos enseñaría posteriormente en sus clases), que no es otra que la del sistema "neoclásico" en la versión de Jiménez de Asúa, esto es, el sistema Liszt-Beling con ciertos añadidos derivados, básicamente, del Tratado de Mezger. Así, no sólo recurre a la traducción del Tratado de Mezger de 1935 para afirmar la necesidad de determinar el bien jurídico protegido en los delitos de malversación, sino, principalmente, para anunciar el concepto de delito que empleará al analizar las figuras de malversación: "acción u omisión típicamente ilícita y culpable", donde la "ilicitud" se identifica como "la contradicción de la acción u omisión con las normas del Derecho"; la "culpabilidad" con "el límite de lo que puede ser imputado al agente de una conducta antijurídica y, además, la forma de esa imputación dolo o culpa"; y la "tipicidad" como la adecuación de la conducta ilícita y culpable a los cuadros delictivos acuñados por la ley en la parte especial". ${ }^{111}$ La parte más "compleja" de esta exposición, por así decirlo, es la forma cómo se incardina en el concepto de delito el de "tipo penal" entendido a la manera de Mezger, como constitutivo de la antijuricidad, abarcando la totalidad delito, o como se cita por Bunster,"la ilicitud concretamente descrita por la ley a través de sus diversos artículos", cuestión que Bunster resuelve afirmando unas líneas más adelante que "concretamente, el tipo penal abarca el sujeto del delito, la acción con sus modalidades y el objeto del delito". No obstante, estima que sigue debiéndose, además, aplicar al

\footnotetext{
en México, desde el año 1981 hasta su muerte, el año 2004.

108 JIMÉNEZ DE ASÚA, Tratado I, cit. nota al pie No, 3 , pp. 1103 y ss.

${ }^{109}$ Revista de Ciencias Penales, T. XII (1950), pp. 148-178. En este texto Bunster opone a una comprensión absolutamente objetiva de la conducta, predominante en la época, la necesidad de considerar en ella "un coeficiente mínimo psíquico". Bunster analiza la discusión italiana existente acerca de si la acción ha de tener o no un "coeficiente psíquico mínimo" distinto de la "referibilidad psíquica" que "pertenece a la culpabilidad", decantándose por lo primero y, en consecuencia, por la elaboración de causas de exclusión de la acción independientes del análisis de culpabilidad. Lo interesante del texto es que muestra la capacidad de Bunster de adaptarse a la discusión dentro de la llamada "Escuela TécnicaJurídica" italiana, cuyos autores (especialmente Antolisei) dominan ampliamente el aparato bibliográfico del mismo. Esta idea, no del todo compatible con la explicación que de la "conducta" ofrece en el texto sobre Malversación que analizaremos enseguida, fue duramente criticada por Novoa, quien en su rigorismo analítico afirmaba que "si no aprovechamos el esfuerzo lógico para dejar claramente diferenciados los elementos que intelectualmente separamos, más valiera no hacer análisis de ninguna especie, ya que, de otro modo la postura analítica conduciría justamente a la confusión que se trata de evitar" ("La conducta, primer elemento del delito", Revista de Ciencias Penales, T.XVIII (1959), pp. 321 , p. 10). Mucho después, Novoa terminaría afirmando la compatibilidad entre esta doctrina del "coeficiente mínimo psíquico" y el "sistema clásico" (NOVOA, Causalismo y finalismo, cit. nota al pie no 102 , p. 28, nota 26). Pero, en contra de ello, para Cury, el "coeficiente psíquico mínimo" de Bunster "evidencia la raíz finalista de su sistema y lo invade lentamente" (CURY, Enrique, "La ausencia de tipicidad en el Código penal", Revista de Ciencias Penales, T. XIX (1960), pp. 51-57, p. 56).

${ }^{110}$ Revista de Ciencias Penales, T.XIV (1954), pp. 67-74. Aquí no se refiere a la teoría jurídica del delito, sino exclusivamente a la cuestión de las finalidades de las penas pues, admitiendo que éstas van desde el "restablecimiento del orden" (en cita a Carrara) hasta una prevención general no siempre lograda, rechaza el retribucionismo ("llevado hasta la puerilidad" por el Código) y apuesta por la prevención especial en su determinación y ejecución.

${ }^{111}$ BUNSTER, Malversación, cit. nota al pie no 67 , p. 2, nota 3, y p. 12, con citas también a Soler.
} 
análisis del delito la idea de "esquema rector" o "delito-tipo", que toma de la traducción del "Esquema de Derecho penal" de Beling hecha por Soler, para determinar si varias figuras legales corresponden o no a un mismo "esquema rector" o "delito-tipo", entendiéndolo como una "imagen unitaria", que "rige comprensivamente varias figuras de delito al mismo tiempo", "de donde se sigue que en la ley penal, son más las figuras delictivas que los delitos-tipos", poniendo el ejemplo del homicidio simple y el calificado: habría un solo "delito-tipo" y varias figuras delictivas. ${ }^{112}$

No obstante lo anterior, existen testimonios de que, en su afán de permanecer al día en la discusión y motivar a sus alumnos, Álvaro Bunster habría sido uno de los primeros en explicar entre nosotros la "teoría de la acción final", alrededor del año 1955, sin que ello significase su plena adhesión al mismo. ${ }^{113}$

\subsection{La nueva bibliografía disponible en la década de 1950 y el ingreso a la discusión del "sistema finalista" de Hans Welzel}

\subsubsection{Los nuevos fondos bibliográficos disponibles}

Como ya hemos señalado, durante las décadas de 1940 y 1950 se produjeron ciertos cambios en la vida universitaria y académica relativa al Derecho penal, que prepararon el terreno para la germinación de una nueva generación de interesados en la materia: la consolidación en el Seminario de Derecho Penal y Medicina Legal de la Universidad de Chile de la enseñanza del Derecho penal desde el punto de vista dogmático ("neoclásico" hasta ese entonces) y del Instituto de Ciencias Penales, que a finales de la década de 1950 obtendría la autonomía financiera que le permitiría adquirir una sede propia y financiar la publicación periódica de su Revista de Ciencias Penales.

Los profesores, ayudantes y alumnos del Seminario y los miembros del Instituto comienzan a recibir un nuevo material bibliográfico, aprovechando no sólo la aparición del extenso Tratado de Jiménez de Asúa, ${ }^{14}$ sino también las traducciones de textos alemanes que aparecen en Argentina y España.

\footnotetext{
${ }^{112}$ BUNSTER, Malversación, cit. nota al pie $\mathrm{n}^{\circ}$ 67, pp. 12, nota 13, p. 13 y p. 18. Sobre esta base estructura la exposición del estudio de las figuras de malversación, tratando en orden los problemas relativos a los sujeto y al objeto del delito (p. 9-40), para luego analizar, separadamente cada una de las formas o "figuras delictivas" de malversación (pues asume que no son reductibles un solo "delito-tipo", p. 19): apropiación de fondos públicos (p. 41-68), distracción de fondos públicos (p. 69 a 94), "malversación por culpa" (p. 95 a 112); desviación hacia fines públicos indebidos (pp. 113 a 121) y la "negativa a efectuar un pago" (p. 123 a 126).

${ }^{113}$ Así lo señala el propio Luis Ortiz Quiroga, quien recuerda sus clases con Bunster ese año y señala que éste "no se abanderizó nunca con el finalismo manteniéndose en una postura equidistante en las tendencias opuestas" ("Entrevista", en BERNALES, Álvaro Bunster, cit. nota al pie no 107, Anexo No 2 , pp. 5-9, p. 7). Esta ambivalencia se demuestra por el hecho de que mientras otra de sus ex estudiantes en Chile, Clara Szczaransky, entrevistada al respecto dice que Bunster adhería al "finalismo de Welzel" y su "impacto en la teoría del delito" ("Entrevista", en BERNALES, Álvaro Bunster, cit. nota al pie n" 107 , Anexo $\mathrm{N}^{\mathrm{o}} 4$, pp. 15s, p. 15); uno de sus “discípulos” mexicanos ofrece una versión contraria: "en el período que lo conocí y en que se cristalizaron algunas reformas que fueron tildadas de "finalistas" en México, criticó vehemente la adscripción o asimilación ciega, principalmente en los ordenamientos penales, a una determinada doctrina" (Alejandro González Gómez, "Entrevista", en BERNALES, Álvaro Bunster, cit. nota al pie $\mathrm{n}^{\circ} 107$, Anexo $\mathrm{N}^{\mathrm{o}} 3$, pp. 10-14, p. 11). En todo caso, parece seguro que la mencionaba y explicaba en sus clases, al menos desde ca. 1955 en adelante.

${ }^{114}$ El Tratado, en siete extensos y eruditos tomos, comenzó a publicarse en 1950 y su segunda edición, en 1957. Para la referencia bibliográfica, ver nota al pie $n^{\circ} 3$.
} 
Polit. crim. Vol. 6, № 11 (Julio 2011), Art. 3, pp. 44 - 105.

[http://www.politicacriminal.cl/Vol_06/n_11/Vol6N11A3.pdf]

En ellas viene el germen de lo que será el sello de buena parte de los miembros de la Nueva Dogmática Chilena: las ideas de Hans Welzel y su "sistema finalista". Por de pronto, las extensas notas de José Arturo Muñoz a la traducción de la segunda edición del Tratado de Mezger (1946), ya dan cuenta de él. ${ }^{115}$ Y también se da cuenta de este nuevo concepto en el texto mismo del Libro de Estudio de Mezger, traducido en $1958,{ }^{116}$ y en los textos de Sauer, ${ }^{117}$ Dohna ${ }^{118}$ y Gallas. ${ }^{119}$

Pero, lo más importante para la difusión de la teoría, aparecen en Buenos Aires dos obras del propio Hans Welzel: en 1951, La teoría de la acción finalista, ${ }^{120}$ y en 1956, la primera traducción de su Derecho penal. ${ }^{121}$

Más tarde, en 1962, aparecerá en Barcelona, la traducción del Tratado de Derecho penal de Maurach, que adopta la sistemática finalista, y donde ya se (des)califica la

\footnotetext{
${ }^{115}$ MEZGER, Tratado, cit. nota al pie no 45, notas del traductor (José ARTURO MUÑOZ) en pp. 190193, y p. 196-211, donde se transcribe parte de la polémica. En la primera de ellas se explicita el concepto "valorativo" y "final" de acción de Mezger, trayendo a colación lo que señalaba en sus Grundrissen en el sentido de que "hacer y dejar de hacer son uno y otro conductas enderezadas a una meta, a un fin, y como tales, 'animadas, impulsadas por la voluntad"”, pues, citando a Liszt, afirma que "el Derecho 'separa la voluntad humana como causa, de todas las restantes causas". Pero, según Mezger, ello no debía conducir "al erróneo resultado de que la acción sólo puede tener como 'efectos' aquellos que son la 'vez contenidos del querer", según afirmaba Welzel, pues ello supondría renunciar a comprender numerosos fenómenos de la vida jurídica "real", como los delitos culposos y los entonces calificados por el resultado. Según Mezger, un concepto de acción como el por él propuesto no tiene nada que ver con una "concepción del positivismo naturalista" o la "irrupción del dogma causal en el Derecho punitivo", según la crítica de Welzel, sino tan sólo con el "simple percibir" y "la observación correcta de los procesos y acontecimientos de nuestra vida jurídica". En la segunda de estas notas, que es casi un artículo completo, se reproduce la crítica de Welzel al concepto "natural" de acción y se esbozan las implicancias sistemáticas de la teoría final de la misma.

${ }^{116}$ MEZGER, Edmund, Derecho penal. Parte general, libro de estudio. Trad. de la $6^{\mathrm{a}}$ Ed. alemana (1955) por C. Finzi, Buenos Aires: Ed. Bibliográfica Argentina, 1958, pp. 89-93.

${ }_{117}$ SAUER, Derecho penal, cit. nota al pie n ${ }^{\circ}$ 53. Allí de nuevo son las "notas" del traductor español (Juan del Rosal), las que conducen al lector a la teoría finalista, como contrapuesta a la de Sauer, como puede verse en las notas al pie de las pp. 96 y 119, sobre el valor de los "elementos subjetivos del tipo" y su carácter "subjetivo", propiamente tal.

${ }^{118}$ DOHNA, Alexander Graf zu, La estructura de la teoría del delito, Trad. C. FONTÁN B., Buenos Aires: Abeledo-Perrot, 1958. Aquí el autor desarrolla la estructura del delito desde un punto de vista finalista, pero sin citar explícitamente a Welzel, poniendo sin más la teoría del dolo y el error en la parte subjetiva del tipo como objeto de posterior valoración en la culpabilidad, que queda así desprovista de elementos psicológicos y se transforma en una "teoría estricta de la culpabilidad" (pp. 32-39), estructura del todo conforme con el planteamiento sistemático de Welzel, según se verá en el texto.

${ }^{119}$ GALLAS, Wilhelm, La teoría del delito en su momento actual, Trad. J. CÓRDOBA R., Barcelona: Bosch, 1959. En el texto aparece claramente expuesta la doctrina de Welzel y la discusión es más bien de carácter intrasistemática entre su éste y Gallas, quien parte reconociendo que "la teoría final de la acción aparece, considerada en su vinculación histórica, como la conclusión provisional de una evolución caracterizada por la progresiva descomposición del sistema de Liszt y Beling (que llamaremos aquí "clásico")" (p. 7).

${ }^{120}$ WELZEL, Hans, La teoría de la acción finalista, Trad. C. FONTÁN B., Buenos Aires: Depalma, 1951.

${ }^{121}$ WELZEL, Hans, Derecho penal. Parte general, Trad. C. FONTÁN B., Buenos Aires: Depalma, 1956. Que este texto se encontraba al poco tiempo disponible para los entonces juristas en formación queda demostrado por la inscripción al margen que se contiene en el ejemplar ingresado como copia $\mathrm{N}^{\mathrm{o}} 1$ a la Biblioteca de la Facultad de Derecho de la Universidad de Chile: “Gibbs-\$115.-m/a-10-XII-57”. Estas mismas inscripciones demuestran lo todavía pobremente dotada que se encontraba esta biblioteca en 1957: figura como en ejemplar $\mathrm{N}^{\mathrm{o}} 1.456$ de la misma.
} 


\title{
MATUS, Jean Pierre "Origen, consolidación y vigencia de la Nueva Dogmática Chilena (ca. 1955 1970)"
}

\author{
postura de Mezger y quienes defendían el sistema "neoclásico" como \\ "conservadora". ${ }^{122}$
}

${ }^{122}$ MAURACH, Reinhart, Tratado de Derecho penal, Trad. J. CÓRDOBA RODA, Barcelona: Ariel, 1962 (Hay que tener en cuenta, además, que Maurach visitó Chile y dio conferencias en la Universidad de Chile, en un momento entre los años 1957 y 1965, Anales de la Facultad de Ciencias Jurídicas y Sociales, Tercera Época, Vol. I (1952-1954), Nos 1-3, p. 239). En el Tratado, Maurach considera el sistema defendido por Mezger, aunque "dominante en la actualidad" (p. 171), como "conservador" y "cerrado" ante la práctica que ya habría aceptado las consecuencias del finalismo, "especialmente en las teorías del error de prohibición, y participación" (p. 193), doctrina que Maurach adopta, tanto en el concepto final de la acción como en sus consecuencias sistemáticas (básicamente, el traslado del dolo a la tipicidad, p. 195). La argumentación subyacente ("neoclásico" = "conservador"; "finalista" = "moderno" / "progresista"), tiene un claro cariz político que hace alusión solapada al entonces todavía reciente ascenso y caída del III Reich en Alemania. Este trasfondo político de la discusión en Alemania (y luego en España) no se abandonaría hasta el día de hoy. En efecto, ya durante el régimen nacionalsocialista se alzó la voz de Luis Jiménez de Asúa para denunciar la complicidad de Mezger con la Dictadura, mediante la adopción de un "concepto unitario" de delito y el abandono del principio de legalidad, como convenía al régimen, en varias de sus obras aparecidas entre 1933 y 1945, que dejaban de lado la sistemática "neoclásica" de la última edición de su Tratado antes del nombramiento de Hitler como Canciller (JIMÉNEZ DE ASÚA, La Ley y el Delito, cit. nota al pie no 39, p.257 y 312). Hoy en día es Muñoz Conde quien con mayor ímpetu ha investigado y denunciado las complicidades de Mezger con el nacionalsocialismo (MUÑOZ CONDE, Francisco, Edmundo Mezger y el Derecho penal de su tiempo. Estudios sobre el Derecho penal en el Nacionalsocialismo, Valencia: Tirant Lo Blanch, 2002). Sin embargo, si el asunto se ha de llevar a ese plano, Welzel no sale mejor parado, pues su "teoría final de la acción" se desarrolló esencialmente durante el régimen nacionalsocialista (y pensada para el "Derecho penal alemán" de entonces), cuyas reformas legales, incluyendo el reemplazo del principio de legalidad por la analogía basada en el "sano sentimiento del pueblo alemán" y "el cambio de acento en el concepto del delito, pasando desde el resultado al lado de voluntad y la conciencia" aprobó Welzel con entusiasmo (con detalle, trascripción de textos de la época y referencias bibliográficas actuales, véase MATUS, La transformación, cit. nota al pie $\mathrm{n}^{\circ} 43$, pp. 147-158). Sólo la mitología creada a posteriori, que creyó ver en Welzel un opositor al régimen nacionalsocialista (aunque, por el contrario, fue miembro del Partido y sus "sociedades científicas" en Göttingen), puede explicar que se recibieran en Chile sus tesis como una suerte de respuesta "frente a esos excesos" nacionalsocialistas que, por la misma fuente mítica se asociaban al "aprovechamiento" por parte de la dictadura de los anteriores conceptos jurídicos "naturalistas", según puede leerse en las primeras páginas del texto de Luis ORTIZ Q., "Algunas consideraciones sobre la teoría de la acción finalista" (Revista de Ciencias Penales, T. XXIV (1965), pp. 3-20 (primera parte) y 101-120 (segunda parte), p. 5s). Allí se afirma que ante la experiencia nacionalsocialista la obra de Welzel "tiende [...] a revalorizar la función ético-social de derecho combatiendo el naturalismo. Para Welzel [...] los valores básicos que deben tomar en consideración el desarrollo de toda comunidad son los que aseguran 'en los ciudadanos el permanente acatamiento legal ante los bienes jurídicos; es decir, la fidelidad frente al Estado, el respeto de la persona (de la vida ajena, la salud, la libertad, honor, etc.)"' (p. 4). Naturalmente, Ortiz Q. creía de buena fe que esta frase se había escrito sólo una vez terminada la guerra y como reacción a ésta, desconociendo que se trataba de una sutil modificación de los "valores positivos de la recta conciencia" que, según Welzel, debía proteger el Derecho penal en el III Reich, según se lee en la tercera edición de su Derecho penal alemán, aparecida en Berlín, el año 1944, esto es, "la lealtad al pueblo, al Reich, a la Führung, la obediencia al poder estatal, la disposición al deber militar, el respeto a los juramentos, etc." (WELZEL, Hans, Das Deutsche Strafrecht in seinen Grundzügen, $3^{a}$ ed., Berlín: De Gruyter, 1944, p. 1).

Por otra parte, aunque no tuviesen un contexto político, el uso de las (des)calificaciones para afianzar argumentos (llamar "conservador" al contrincante, por ejemplo) en la querella entre finalismo y causalismo, ya había llamado la atención a NOVOA, Causalismo y finalismo, cit. nota al pie $\mathrm{n}^{\circ} 102$, quien se quejaba contra la forma desdorosa y soberbia con que algunos partidarios del finalismo en América Latina enfrentaban la discusión, llegando a "suponer falta de inteligencia o de discernimiento crítico en el adversario", tratándolos de "ingenuos" y "candorosos" y hasta "atribuirle torcidos propósitos", mediante el empleo de expresiones como "proceder tramposo", "esconder inconsistencias", "caer en la propia trampa" o "acudir a hábil escamoteo verbalista" (pp. 144 y ss., y sus notas al pie 143 y 144).

En general, sobre este "estilo" de la discusión entre penalistas, véase mi "Por qué citamos a los alemanes y otros apuntes metodológicos", Política Criminal, $\mathrm{N}^{\mathrm{N}} 5$ (2008), A5-5. pp. 1-33. 
Polit. crim. Vol. 6, № 11 (Julio 2011), Art. 3, pp. 44 - 105.

[http://www.politicacriminal.cl/Vol_06/n_11/Vol6N11A3.pdf]

\subsubsection{La teoría de la acción final (en la traducción argentina de 1956)}

En cuanto al contenido de la teoría final de la acción en sí, en la traducción de su Derecho Penal de 1956, Welzel comienza afirmando que su sistema se encuentra"en posición diametralmente opuesta" a la "creencia errónea positivista" que "supone que el Derecho en su integridad es un producto del legislador; que el legislador puede administrar arbitrariamente la materia jurídica" y que la dogmática es, por tanto "sólo la elaboración técnica de esta materia jurídica "casual", pues "si esto fuera cierto, entonces estarían acertadas las palabras del procurador del Estado, von Kirchmann, sobre la ciencia jurídica: 'Tres palabras rectificadoras del legislador, y bibliotecas enteras se convierten en inútiles pliegos impresos"”.

En cambio, sostiene que el sistema de la teoría final de la acción

"parte de la convicción de que el legislador no es en manera alguna omnipotente, y que está ligado a determinados límites dados en la materia del derecho. Encontrar y llevar al conocimiento esos límites, es la misión de la tarea científica en derecho penal"

En su teoría, ese límite estaría dado por el entendimiento de que "las normas del derecho penal, vale decir, sus imposiciones y prohibiciones, pueden dirigirse únicamente a acciones humanas" y que "sólo en cuanto alcancen el poder finalista de creación de las acciones humanas sobre los acontecimientos de la naturaleza, el derecho puede imponer o prohibir algo a las acciones". Por lo tanto,

"ese poder configurador de una acción humana, junto con los elementos que la constituyen, le está dado al derecho. Éste no los puede crear ni modificar. No puede sacarles ni agregarles nada. A estos elementos constitutivos de la acción, vale decir, a los elementos objetivos y subjetivos de la acción y su relación entre sí, deben vincularse las características delictuales del derecho (adecuación típica, antijuricidad, culpabilidad). También ellas deben aceptar los elementos de la acción en la forma que realmente tienen". ${ }^{123}$

El concepto de delito se construye así sobre la idea de que

"todo hecho penal es una acción contraria a la sociedad, por la que el autor, como personalidad, es responsable. Responsabilidad personal (culpabilidad) por un hecho contrario a la sociedad (lo injusto), son los dos componentes fundamentales del injusto.", 124

Pero, en cuanto a la tipicidad del injusto, todavía habría que distinguir dos "tipos de injusto":

a) aquél en que "las acciones finalistas, cuya voluntad de concreción está dirigida hacia la realización de resultados socialmente, son calificadas de antijurídicas por el derecho en los tipos de los delitos dolosos: como asesinato, homicidio, hurto, etc."; y

[http://www.politicacriminal.cl/n_05/a_5_5.pdf], p. 10, nota al pie 34, con referencias a la discusión argentina al respecto entre Malamud y Maier.

${ }^{123}$ WELZEL, Derecho penal, cit. nota el pie No 121 , pp. vii y ss.

${ }^{124}$ WELZEL, Derecho penal, cit. nota el pie No 121 , p. 57. 


\section{MATUS, Jean Pierre "Origen, consolidación y vigencia de la \\ Nueva Dogmática Chilena (ca. 1955 1970)"}

b) y el referido a "las acciones que, contempladas en sus consecuencias causales, no observan el mínimo jurídicamente indicado de dirección finalista", que "son comprendidas por los tipos de los delitos culposos como 'lesiones imprudentes o negligentes de bienes jurídicos"." ${ }^{25}$

En esos tipos de injusto de acción finalista prohibida o con falta del mínimo exigido, esa acción es antijurídica en la medida que está en "descuerdo" "con las exigencias que impone el derecho para las acciones que se realizan en la vida social":

"la 'antijuricidad' es un juicio de valor 'objetivo', en cuanto se realiza sobre la acción, en base a una escala general, precisamente del orden social jurídico. El objeto que se valora, a saber, la acción, es, en cambio, una unidad de elementos objetivos (del mundo exterior) y subjetivos (psíquicos)". ${ }^{126}$

Y, en cuanto a la culpabilidad, "agrega a la acción antijurídica -sea la concreción dolosa de un tipo, sea la lesión no dolosa de diligencia- un nuevo elemento, a través del cual se convierte recién en delito": "el reproche personal por no haber omitido la acción antijurídica, a pesar de haberla podido omitir". Ella "es solamente la reprochabilidad como valoración de la voluntad de acción; objeto de esa valoración es la voluntad antijurídica de acción (y por ello, toda la acción antijurídica)". ${ }^{127}$

De allí que, radicado dolo y culpa en la tipicidad, como elementos de la acción, la sistemática impone a Welzel aceptar la llamada "teoría normativa" "estricta" de la culpabilidad, anticipada por Dohna, que "elimina los elementos subjetivos-psíquicos y retiene solamente el elemento normativo de la reprochabilidad". ${ }^{28}$

\section{La Nueva Dogmática Chilena (ca. 1955 1970)}

\subsection{Sus integrantes}

En la introducción de este texto hemos mencionado varios penalistas que se consideran como miembros de las "nuevas" y "antiguas" generaciones de dogmáticos chilenos. Y hasta este lugar, hemos identificado a los representantes principales de las generaciones de los años 1925-1940 y 1940-1955, señalando las semejanzas y diferencias entre ambas, así como los vínculos intergeneracionales existentes. La pregunta acerca de quiénes son los más representativos miembros de la Nueva Dogmática Chilena se resuelve, por tanto, de la misma manera, esto es, identificando a los que, habiendo finalizado su formación universitaria alrededor del año 1955, comparten ciertas características en su formación y en la exposición ante eventos significativos comunes.

Para ello, diremos que entendemos como Nueva Dogmática Chilena al conjunto de estudiosos del Derecho penal cuya formación universitaria tuvo lugar en la década de 1950, terminando sus cursos de pregrado alrededor del año 1955, y que llegarían a ocupar un lugar importante en la discusión dogmática de la década de 1960,

\footnotetext{
${ }^{125}$ WELZEL, Derecho penal, cit. nota el pie No 121 , pp. 42 y ss.

${ }^{126}$ WELZEL, Derecho penal, cit. nota el pie No 121 , p. 57.

${ }^{127}$ WELZEL, Derecho penal, cit. nota el pie no 121 , pp. 147 y 149.

${ }^{128}$ WELZEL, Derecho penal, cit. nota el pie no 121 , pp. 151. Welzel cita aquí la edición de 1941 del Aufbau de Dohna. Sobre esta anticipación de la sistemática finalista por parte de Dohna, véase la nota al pie $n^{\circ} 118$.
} 
Polít. crim. Vol. 6, No 11 (Julio 2011), Art. 3, pp. 44 - 105.

[http://www.politicacriminal.cl/Vol_06/n_11/Vol6N11A3.pdf]

principalmente a través de su participación en el Instituto de Ciencias Penales, su transformación en Profesores de Derecho Penal, y sus contribuciones escritas aparecidas entre 1955 y 1970 . El evento significativo que compartieron en su formación fue el contacto con Álvaro Bunster en el Seminario de Derecho Penal y Medicina Legal de la Universidad de Chile. Y por lo mismo, los miembros de la Nueva Dogmática Chilena no fueron "autodidactas", sino que, por regla general, realizaron sus Memorias de Grado en temas dogmáticos. Ello incidió en que tampoco estuvieran expuestos al positivismo criminológico, pero sí, en cambio a la discusión entre el "sistema clásico" y el "sistema finalista", tomando partido por alguno de ellos (y, mayoritariamente, por el finalista). Otra particularidad de esta generación fue la realización de estudios de postgrado en España, Alemania o Italia. Desde el punto de vista social, los miembros de la Nueva Dogmática Chilena estuvieron expuestos también a los "procesos" de "cambios" que en todos los ámbitos de la vida social se experimentaron a partir de 1960 (lo que se reflejaba en el claro compromiso político de algunos de sus miembros) y, por ende, a los trastornos que para el país y sus propias vidas provocaría el Golpe de Estado de 1973, que pondría fin a ese período.

Los penalistas miembros de la generación que hemos denominado Nueva Dogmática Chilena son los siguientes (en orden alfabético):

Nueva Dogmática Chilena (ca. 1955 1970)

- Juan Bustos R. (1935-2008);

- Enrique Cury U. (1933-);

- Alfredo Etcheberry O. (1931-);

- Francisco Grisolía C. (1928-2005);

- Luis Ortiz Q. (1934-);

- Sergio Politoff L. (1930-2009)

- Miguel Schweitzer W. (1940-)

- Jaime VivancoS. (ca. 1934-);

- Sergio Yáñez P. (1925-2006).

Sobre su formación, desarrollo personal y vigencia actual de su obra trataremos en los siguientes apartados de este trabajo.

\subsection{Formación de la Nueva Dogmática Chilena}

3.2.1. Álvaro Bunster, el "Curso Profundizado" de 1956 y los estudios de posgrado en el extranjero

Según relata Luis Ortiz Q., el último año de sus estudios de Derecho (1956),

"un pequeño grupo de 17 alumnos nos inscribimos en un curso de Derecho Penal Profundizado sobre 'La Culpabilidad'. Creo no equivocarme si los 17 que estudiamos con Álvaro durante ese año terminamos haciendo la Memoria cada uno en un tema vinculado con la culpabilidad, especialmente motivados por la calidad y entusiasmo con que enseñaba". 


\section{MATUS, Jean Pierre "Origen, consolidación y vigencia de la Nueva Dogmática Chilena (ca. 1955 1970)"}

\section{Y agrega:}

"Creo que Álvaro fue en verdad un destacado jurista en Derecho penal, que no sólo había leído mucho (hablaba italiano y podía leer alemán) sino además porque supo enseñar a un gran nivel y formar un grupo de discípulos que, estimulados por su entusiasmo, siguieron sus pasos en la Cátedra. Así ocurrió con Etcheberry, Politoff, Armando Uribe, Sergio Román, Jaime Vivanco, Miguel Schweitzer [W.] y yo mismo, para nombrar aquellos que recuerdo". ${ }^{129}$

En efecto, entre 1954 y 1965, Álvaro Bunster dirigió las memorias de Alfredo Etcheberry, ${ }^{130}$ Sergio Politoff, ${ }^{131}$ Luis Ortiz, ${ }^{132}$ y Jaime Vivanco. ${ }^{133}$ Y también fue profesor de cátedra y director de la Memoria de Enrique Cury U. ${ }^{134}$ Por otra parte, según relata el propio Grisolía, aunque Bunster no fue formalmente el Director de su Memoria, materialmente le guío en su realización. ${ }^{135}$

${ }^{129}$ Esta cita y la anterior corresponden a ORTIZ Q., Luis, "Entrevista”, cit. nota n 138 , pp. 5 y 9 ,
respectivamente. La existencia de este curso ha sido confirmada por diversas fuentes y consta por escrito
en la Introducción de la Memoria de Prueba de Armando URIBE (De los delitos calificados por el
resultado, Tesis UCh, Santiago: Ed. Jurídica, 1957).
${ }^{130}$ ETCHEBERRY, El concurso aparente, cit. nota al pie no 68, [Reseña en Revista de Ciencias Penales, T. XV (1956), No 1, p. 117]. Para más detalles sobre su vida académica y publicaciones posteriores, véase la nota al pie $\mathrm{n}^{\mathrm{o}} 164$.

${ }^{131}$ POLITOFF L., Sergio, El delito de apropiación indebida, Santiago: Ed. Nascimento, 1957 [Reseña en Revista de Ciencias Penales, T. XVII (1958), No 1, p. 53]. Para más detalles sobre su vida académica y publicaciones posteriores, véase la nota al pie $\mathrm{n}^{\mathrm{0}} 182$.

${ }^{132}$ ORTIZ Q., Luis, Teoría de las hipótesis preterintencionales, Tesis UCh, Santiago: Ed. Jurídica, 1959 [Reseña en Revista de Ciencias Penales, T. XVIII (1959), No 1, p. 160]. Después, viaja a Roma donde obtiene el Diploma de Especialización de la Sapienza. A su regreso Ortiz Q. enfrentó derechamente la disputa sistemática en su artículo "Algunas consideraciones..." (cit. nota al pie $\mathrm{n}^{\circ} 122$ ). Entre tanto, en 1965 es nombrado "Profesor Agregado" de Derecho penal, (Anales de la Facultad de Ciencias Jurídicas y Sociales, Cuarta Época, Vol. VIII (1967), № 7, p. 151-156). Actualmente es Profesor Titular del Departamento de Ciencias Penales de la Universidad de Chile y ejerce activamente la profesión.

${ }^{133}$ VIVANCO S., Jaime, El delito de robo con homicidio. Ensayo a la luz de la doctrina del delito-tipo, Tesis UCh, Santiago: Ed. Jurídica, 1957 [Reseña en Revista de Ciencias Penales, T. XVII (1958), Nº 1, p. 54]. Esta es la primera memoria chilena que aplica rigurosamente la dogmática alemana al estudio de un delito en particular, como indica su significativo subtítulo. Trabaja como Redactor de la Revista de Ciencias Penales y publica numerosos comentarios y notas de sentencias, así como partes de su Memoria. En 1970, es nombrado "Profesor agregado Derecho penal, ad-honorem" (Anales de la Facultad de Ciencias Jurídicas y Sociales, Cuarta Época, Vol. XI (1970), $\mathrm{N}^{\circ} 11$, p. 13). En ese año publicó, en conjunto con Francisco GRISOLÍA y Jaime NÁQUIRA, el artículo "La remisión condicional de la pena y la libertad condicional en el sistema chileno de ejecución de sanciones", Revista de Ciencias Penales, T. XXXII (1973), pp. 93-110. Actualmente está radicado en Iquique, donde ejerce la profesión y participa en la vida universitaria de la zona.

${ }^{134}$ CURY U., Enrique, El delito continuado, Tesis UCh, Santiago: Ed. Jurídica, 1962 [=Revista de Ciencias Penales, T. XVIII (1959), pp. 104-123 (primera parte) y pp. 201-215 (segunda parte), p. 204]. Cury reconoce esta vinculación en una "Entrevista" posterior (BERNALES, Álvaro Bunster, cit. nota al pie $\mathrm{n}^{\mathrm{o}} 107$, Anexo $\mathrm{N}^{\mathrm{0}} 1$, pp. 2-4, p. 2), con lo que se aclara la duda planteada al respecto en MATUS, "Fernández, Fuenzalida, Vera...", cit. nota al pie $n^{\circ} 12$, nota al pie $n^{\circ} 108$. Para más detalles sobre las publicaciones y el desarrollo académico posterior de Cury, véase la nota al pie no 169 .

${ }^{135}$ GRISOLÍA, Francisco, El objeto jurídico del delito. (Prolegómenos para el estudio de la objetividad jurídica en los delitos de Falsedad documental), Santiago: s/e, 1959, p. v. Con todo, se debe señalar que, producto del fenómeno de la coexistencia generacional antes descrito, Francisco Grisolía reconocía como "maestro" no a Bunster, sino a Miguel Schweitzer S., de quien sería ayudante de Cátedra (pp. 1 y 3 ). Francisco Grisolía se incorporó como Ayudante Investigador del Seminario de Derecho Penal y Medicina Legal de la Universidad de Chile el año 1963. Ya en 1970 aparece ganando los concursos para "Profesor agregado Derecho penal, ad-honorem" y "Profesor auxiliar Derecho penal, Media jornada" (Anales de la Facultad de Ciencias Jurídicas y Sociales, Cuarta Época, Vol. XI (1970), No 11, p. 163). Fue Secretario 
Polit. crim. Vol. 6, № 11 (Julio 2011), Art. 3, pp. 44 - 105.

[http://www.politicacriminal.cl/Vol_06/n_11/Vol6N11A3.pdf]

Por lo que toca a la vinculación de Bunster con Juan Bustos ${ }^{136}$ y Sergio Yáñez, ${ }^{137}$ baste decir que ellos cursaron sus carreras cuando Bunster ya era profesor en la Universidad de Chile y se incorporaron como Ayudantes de investigación del Seminario de Derecho Penal y Medicina Legal, al regreso de sus estudios en Alemania, el año 1965, último año en que Bunster ejerció efectivamente como Director del Seminario de Derecho Penal y Medicina Legal.

La cuestión es discutible en el caso de Miguel Schweitzer W., por cuanto, a pesar de la fecha de su titulación (1964) y la referencia que hace Luis Ortiz, al considerarlo también un "discípulo" de Bunster, ${ }^{138}$ el propio Schweitzer W. parece desconocer este vínculo, quizás por tratarse del más joven entre ellos, ya que nació el año $1940 .{ }^{139}$ No obstante, creemos que es mejor considerarlo dentro de la Nueva Dogmática Chilena, por compartir la mayor parte de los rasgos esenciales de ésta.

Ejecutivo del Instituto de Ciencia Penales y Director de la Revista de Ciencias Penales desde 1967 hasta su jubilación, el año 1992 (no obstante, en 1981 aparece el último tomo bajo su dirección exclusiva [T. XXXVII], el siguiente aparece dirigido por Yáñez y el subsiguiente por ambos en conjunto). Francisco GRISOLÍA falleció el año 2005. Para más antecedentes sobre su persona, véase la nota necrológica en Schweitzer W., Nullum crimen, cit. nota al pie $\mathrm{n}^{\circ} 11$, p. 12 y el artículo periodístico de Vivian BULLEMORE, "En memoria de Francisco Grisoli a Corbato n”, La Semana Jurídica, No 239 (2005), p. 15.

${ }^{136}$ Juan Bustos R. es uno de los primeros miembros de esta generación que obtiene un título formal de Doctor en Derecho, primero en España (La valoración objetiva y subjetiva en la teoria de la acción, Madrid: Univ. Complutense, Tesis inédita, ca. 1960), y luego en Bonn, bajo la dirección de Hans Welzel (Tesis: Finalität, fahrlässiges Begehungs deliktund chilenisches Strafgesetzbuch, Uni-Bonn: Diss., 1965). Para más detalles sobre su vida, véase la nota al pie $\mathrm{n}^{\circ} 172$.

${ }^{137}$ Sergio Yáñez realizó estudios de posgrado en la especialidad, con una estadía en Alemania, financiada por una beca de la Fundación Alexander von Humboldt, a principios de la década de 1960, sin 1legar a doctorarse formalmente. En cuanto a su formación anterior, hay que señalar que su Memoria de Prueba no versó sobre Derecho Penal y, por lo tanto, puede ser considerado como el último autodidacta entre nosotros, algo anómalo entre los miembros de su generación (véase MATUS, Jean Pierre, "Sergio Yáñez, obra e influencia. La dogmática chilena actual”, Revista de Derecho (Coquimbo), Año 14 (2007), N 1, pp. 113-130, p. 115). Posteriormente, destaca su colaboración en la traducción de Juan BUSTOS del Derecho penal alemán de Welzel (Santiago: Ed. Jurídica, 1969), y su trascendente contribución a la discusión sobre los "Problemas básicos de la autoría y la participación en el Código penal chileno" (en Rivacoba y Rivacoba, Manuel (ed.), Actas de las Jornadas Internacionales de Derecho penal en celebración del centenario del Código penal chileno, Valparaíso: Edeval, pp. 161-181). Fue Ayudante del Seminario de Derecho Penal y Medicina Legal de la Universidad de Chile desde 1965. En 1967 obtiene una plaza de Profesor en la Universidad Católica y, en 1968, otra en la Chile. Tras el Golpe de Estado, puesto en la vereda política contraria de Novoa, Politoff y Bustos, colaboró con la Dictadura como asesor legislativo de la Junta de Gobierno. Además, ejerció diversos cargos en las dos universidades (Católica de Santiago y de Chile) en que trabajó toda su vida. No ejerció activamente la profesión, pero llegó a ser nombrado Presidente del Instituto de Ciencias Penales entre 1991 y el día de su muerte, ocurrida el 30 de marzo de 2006. Para más detalles biográficos, véase ULLOA U., Joselyn, Vida, obra e influencia en el Derecho penal chileno de Sergio Yáñez Pérez, Tesis UTal, Talca, 2006 (Prof. Guía: JP MATUS).

${ }^{138}$ Luis Ortiz Quiroga "Entrevista", en BERNALES, Álvaro Bunster, cit. nota al pie n 107, Anexo No 2, p. 5 .

${ }^{139} \mathrm{Su}$ Memoria de Grado, El error de derecho en materia penal (Santiago: Ed. Jurídica, 1964), fue dirigida por Alfredo Etcheberry, siendo el más joven miembro de esta generación. En 1967, a su regreso de Italia, se incorporó al cuerpo de colaboradores de la Redacción de la Revista de Ciencias Penales. El año pasado se omitió de la lista de los discípulos de Bunster que preparó para su nota necrológicas (Nullum crimen, cit. nota al pie $\mathrm{n}^{\mathrm{o}} 11$, p. 9). Schweitzer W. fue Profesor de Derecho penal de la Universidad de Chile y es actualmente Decano y Profesor de Derecho Penal de la Universidad (privada) "Finis Terrae". 
MATUS, Jean Pierre "Origen, consolidación y vigencia de la

Nueva Dogmática Chilena (ca. 1955 1970)"

Además, es de suponer que Bunster estimuló y colaboró, mediante sus contactos, a que Luis Ortiz Q., Sergio Politoff L. y Miguel Schweitzer W. realizaran su Diploma de Especialización en Derecho Penal en la Scuola di Perfezionamento in Diritto Penal de la Universidad La Sapienza de Roma. ${ }^{140}$

Finalmente, cabe señalar que también Alfredo Etcheberry, Jaime Vivanco y Francisco Grisolía realizaron estudios en el extranjero, el primero en los Estados Unidos, el segundo en Francia y España, y el tercero en España. ${ }^{141}$

\subsubsection{La Reforma Universitaria de la década de 1960}

El proceso de Reforma Universitaria en la Facultad de Derecho de la Universidad de Chile se inició con la Reforma al Plan de Estudios del año 1966. En ésta se contemplaba impartir la enseñanza a través de dos métodos estimados "perfectamente compatibles": la "clase magistral tradicional" y "los trabajos complementarios", en los cuales jugarían un rol preponderante los llamados "seminarios" de "investigación" y los "equipos docentes" de cada cátedra. Se entendía por "Seminario" el "método de enseñanza de materias comprendidas en el programa en que un grupo de alumnos dirigidos por un docente investigan y debaten un tema monográfico durante un período de trabajo colectivo." Y, además, se fijaba un horario común para ellos "a fin de conseguir que estas tareas se realicen en grupos reducidos." $" 142$

La implementación de un plan de esta naturaleza suponía dos elementos clave: a) contar con "equipos docentes"; y b) contar con una biblioteca que permitiera la investigación por parte de los alumnos.

Lo primero permitió la rápida incorporación a la Universidad de quienes tenían vocación para ello; y lo segundo, consolidó el acervo bibliográfico disponible. Ambas condiciones permitieron el desarrollo intelectual y académico de la Nueva Dogmática Chilena en la década de 1960.

\subsubsection{Eduardo Novoa Monreal y las actividades del Instituto de Ciencias Penales}

Eduardo Novoa Monreal asumió la Presidencia del Instituto de Ciencias Penales en abril de 1959, cargo que ejerció hasta abril de 1969. Ya había finalizado el proceso de adquisición del inmueble que sería su sede y de su alhajamiento, encabezado por su

\footnotetext{
${ }^{140}$ Sergio Politoff L. obtuvo este Diploma el año 1963, con una tesis titulada Gli elementi soggettivi della fattispecie legale, posteriormente aparecida en Chile (Los elementos subjetivos del Delito, Santiago: Ed. Jurídica de Chile, 1965), trabajo con el que obtuvo el título de Profesor Extraordinario en la Universidad de Chile, el 5 de agosto de 1965 (Anales de la Facultad de Ciencias Jurídicas y Sociales, Cuarta Época, Vol. VI (1966), N 6, p. 110). Luis Ortiz Q. presentó su Tesis de Laurea en la Universidad de Roma el año 1959. Miguel Schweitzer W. aprobó la tesis Sull'elemento soggettivo del reato di bancarotta dell'imprenditore en 1966, apareciendo publicado un resumen en la Revista de Ciencias Penales del año 1967 (ver nota al pie $\mathrm{N}^{\circ} 139$ ).

${ }^{141}$ Alfredo Etcheberry obtuvo el título de Master in Comparative Law, en la Universidad de Columbia, NY (ca. 1959). Según Sergio Politoff, Jaime Vivanco realizó estudios de posgrado en España y Francia (POLITOFF, Sergio, "Prólogo", en Vivanco, Jaime, El Delito de Robo con Homicidio, $2^{a}$ ed., Santiago: Ed. Conosur, 2000, p.5). Francisco Grisolía se doctoró en Derecho por la Universidad Complutense, con la Tesis (inédita) El Código penal tipo para Hispanoamérica: proceso formativo y estudio crítico trabajo, Tesis UCM, 1967.

${ }^{142}$ Anales de la Facultad de Ciencias Jurídicas y Sociales, Cuarta Época, Vol. VI (1966), No 6, pp. 23 y SS.)
} 
Polit. crim. Vol. 6, № 11 (Julio 2011), Art. 3, pp. 44 - 105.

[http://www.politicacriminal.cl/Vol_06/n_11/Vol6N11A3.pdf]

antiguo Presidente, don Daniel Schweitzer S., gracias a los recursos que se obtenían con la Ley que le otorgaba, desde 1956, autonomía financiera. Novoa se preocupó, por lo tanto, de dar curso a los intereses permanentes del Instituto: dotar a la Biblioteca de la mejor literatura disponible en ese momento, ${ }^{143}$ que la Revista de Ciencias Penales mantuviese la regularidad que correspondía, organizar conferencias y cursos de profesores extranjeros, ${ }^{144}$ y, a partir de 1963, impulsar su proyecto de Código Penal Tipo para Latinoamérica. ${ }^{145}$

Estas cuatro actividades principales del Instituto repercutieron fuertemente en la entonces nueva generación de penalistas: se les dio acceso a nueva y actualizada bibliografía; la oportunidad de contactarse con profesores de todo el continente; y el espacio donde canalizar sus inquietudes dogmáticas, mediante la publicación de artículos, comentarios de sentencia y notas bibliográficas.

En este lugar, sólo haremos especial hincapié en la forma cómo se logró crear, a través de la Revista de Ciencias Penales, el espacio privilegiado de discusión científica en que se expresó la Nueva Dogmática Chilena. ${ }^{146}$

Lo primero que se hizo fue procurar asegurar su financiamiento y difusión. Para ello, según cuenta la Memoria de Actividades del año 1959, se estableció una suscripción obligatoria con parte de la cuota social (entonces había 86 miembros activos) y se revitalizó el convenio de suscripción existente desde 1958 con la entonces existente Junta de Servicios Judiciales, con lo cual es esperaba "paliar en un porcentaje más o menos apreciable el considerable sacrificio pecuniario que significa la publicación regular de la revista, y las nuevas modalidades implantadas". Esas "nuevas modalidades" consistieron en "el nombramiento de un secretario de redacción

\footnotetext{
${ }^{143}$ Para lo cual, en palabras de Jiménez de Asúa, no se había "reparado en gastos" (JIMÉNEZ DE ASÚA, Prólogo, cit. nota al pie No 4, p. 9). Se adquirieron obras dogmáticas editadas en España, Argentina, Alemania e Italia, así como de suscripciones a Revistas de primer orden (entre ellas, el Anuario de Derecho Penal y Ciencias Penales de España, la Zeitschrift für die gesamte Strafrechtswissenschaft y la Rivista italiana di diritto e procedura penale), que permitieron a esta nueva generación tener acceso directo a las fuentes y nuevas ideas desarrolladas en los centros del pensamiento dogmático. Para hacerse una idea de este esfuerzo, valga el siguiente dato: el mismo año en que asumió la Presidencia (1959), Novoa duplicó la cantidad de títulos de la biblioteca, pasando de 446 a 995, principalmente mediante una importación directa desde argentina (Instituto de Ciencias Penales, "Memoria de las actividades desarrolladas entre los meses de abril de 1959 y marzo de 1960", Revista de Ciencias Penales, T. XIX (1960), pp. 118-120, p. 119). A este ritmo, en poco menos de 8 años, el número de ejemplares de la Biblioteca se había multiplicado por diez: ya se contaba con 4.478 títulos (Instituto de Ciencias Penales, "Memoria de las actividades realizadas entre los meses de abril de 1966 y marzo de 1967", Revista de Ciencias Penales, T. XXVI (1967), pp. 111-116, p. 112).

${ }^{144}$ Según la Memoria citada en la nota anterior, en 1959 visitaron el Instituto, el Prof. Ponsold, Catedrático de Medicina Legal en la Universidad de München, y Luis Jiménez de Asúa.

${ }^{145}$ MATUS, "La (fallida) recodificación...", cit. nota al pie $\mathrm{n}^{\circ} 11$, pp. 185-189. El Instituto asumió en esta década, además, la calidad de "Grupo Chileno de la Asociación Internacional de Derecho Penal", enviando a miembros de su Directiva a los Congresos Internacionales que se realizaban en la época.

${ }^{146}$ El Instituto también mantuvo un espacio de discusión permanente, pero de carácter oral y personal, mediante la realización de Seminarios, Clínicas y Mesas Redondas a cargo de sus socios e invitados. (Instituto de Ciencias Penales, "Memoria" (1959), cit. nota al pie $n^{\circ} 143$, p. 119). E incluso inició proyectos de investigación propios, como el del Repertorio de giros y voces de la Legislación Penal Chilena, encargado a Armando Uribe (Santiago: Ed. Jurídica, 1965), y la muy relevante traducción del Derecho Penal de Hans Welzel, encargada a Juan Bustos (Instituto de Ciencias Penales, "Memoria de las actividades realizadas entre los meses de abril de 1967 y marzo de 1968", Revista de Ciencias Penales, T. XXVII (1968), pp. 99-103, p. 102).
} 


\section{MATUS, Jean Pierre "Origen, consolidación y vigencia de la Nueva Dogmática Chilena (ca. 1955 1970)"}

remunerado y una planta permanente de redactores", y "el pago de todos los trabajos que se publiquen". ${ }^{147}$

Según aparece en la contraportada del $N^{o} 2$ del T. XIX (mayo-diciembre de 1960), el primer "Secretario de Redacción" remunerado de la Revista fue Francisco Grisolía, siendo los primeros "redactores permanentes" remunerados Enrique Cury, Waldo Ortúzar, Armando Uribe y Jaime Vivanco. En abril de 1960 Alfredo Etcheberry O., recién llegado de sus estudios de posgrado en Estados Unidos e incorporado al Seminario de Derecho Penal y Ciencias Penales de la Universidad de Chile, sucedió en el cargo de Director de la Revista a Álvaro Bunster. En 1961 se incorporan como "redactores permanentes" remunerados Antonio Bascuñán V. y Sergio Politoff. En 1966, con Grisolía en España, asume como Secretario de Redacción remunerado Juan Bustos. Ese año deja transitoriamente la redacción Vivanco. En 1967, a su regreso de España, asume la Dirección de la Revista Francisco Grisolía. Como "Secretario de Redacción" se mantiene Juan Bustos y se crea el nuevo cargo de "Consejero de redacción", en lugar de los antiguos "redactores permanentes", el que asumen Sergio Politoff y Sergio Yáñez. Los antiguos redactores pasan a ser "colaboradores" y su lista se amplía en la misma medida que mengua la colaboración de cada uno de ellos en particular. ${ }^{148}$ Esta estructura se mantiene hasta 1970, en que, con nuevo Directorio en el Instituto, se crea el nuevo cargo de "Subsecretario de Redacción", que asume Jorge Mera y comienza a integrarse a él una nueva generación de penalistas.

Con estas medidas, la Revista adquirió una regularidad de que antes no había gozado. Se publicaron artículos de autores italianos, ${ }^{149}$ alemanes, ${ }^{150}$ españoles, ${ }^{151} \mathrm{y}$ latinoamericanos, ${ }^{152}$ junto con los aportes de autores nacionales de todas las generaciones que coexistían en ese momento ${ }^{153} \mathrm{y}$, especialmente, de los miembros de la

\footnotetext{
${ }^{147}$ Instituto de Ciencias Penales, "Memoria" (1959), cit. nota al pie no 143, p. 119.

${ }^{148}$ En esta nueva estructura, sólo el "Secretario" y los "Consejeros de Redacción" eran remunerados, actuando los restantes ad-honorem, lo que explica el aumento de su número y, al mismo tiempo, la intermitencia de sus colaboraciones (Instituto de Ciencias Penales, "Memoria (1967)", cit. nota al pie $n^{\circ}$ 148, p. 100).

${ }^{149}$ Por ej., Giulano VASSALLI (“Criminología y Justicia Penal”, T. XIX (1960), pp. 3-50); Giovanni LEONE ("El Tributo que la humanidad le debe a César Beccaria", T. XXIII (1964), pp. 3-18).

${ }^{150}$ Por ej., Reinhart MAURACH ("Les príncipes fundamentaux de la théorie de la loipénal et de la construction du crime dan la partiegénérale du Project 1962", T. XXIV (1965), pp. 121-137; y "La fixation de la peine criminelleselon le droit actuell et le projet du 1962", T. XXV (1966), pp. 26-39); Wolfgang Schöne ("Menores disociales en la República Federal Alemana", T. XXVIII (1969), pp. 99118).

${ }^{151}$ Por ej., Juan Antonio GISBERT ("El trastorno mental transitorio según la legislación y la jurisprudencia españolas”, T. XXV (1966), pp. 3-25); Manuel COBO (“Función y naturaleza del artículo 226 del Código penal español", T. XXVI (1967), pp. 127-150); Juan del ROSAL ("Meditación crítica sobre la modificación de los delitos de la circulación”, T. XXVII (1968), pp. 3-34); Antonio BERISTAIN ("La reforma del Código penal Alemán", T. XXVIII (1969), pp. 46-63).

${ }^{152}$ Por ej., en el T. XXII (1963), se encuentran artículos de Niceto ALCALÁ ZAMORA, de México (“Constituyen "injurias causadas en juicio" las proferidas en un procedimiento de jurisdicción voluntaria?", pp. 27-39); Heleno Claudio FRAGOSO, de Brasil ("Notas sobre el concepto de delito en el Derecho soviético", pp. 297-303"); y Fernando REYES, de Colombia ("Contribución al debate sobre la conveniencia de incriminar el adulterio del marido", pp. 304-313). En otro tomo aparece Enrique AFTALIÓN, de Argentina ("El bien jurídico tutelado por el Derecho penal económico", T. XXV (1966), pp. 79-91).

${ }^{153}$ Por ej., en el Tomo XIX (1960), aparecen un artículo de Luis COUSIÑO Mac Iver ("La interpretación de la ley penal en la dogmática chilena”, pp. 197-218), uno de Eduardo NOVOA Monreal ("Algunas consideraciones acerca de la tentativa", pp. 3-32), y dos de Alfredo ETCHEBERRY ("El objeto jurídico
} 
Polit. crim. Vol. 6, № 11 (Julio 2011), Art. 3, pp. 44 - 105.

[http://www.politicacriminal.cl/Vol_06/n_11/Vol6N11A3.pdf]

Nueva Dogmática Chilena llenaron sus páginas de notas bibliográficas, comentarios jurisprudenciales y aportes originales. ${ }^{154}$

\subsection{La disputa sistemática en la Nueva Dogmática Chilena}

\subsubsection{El predominio de la "teoría de la acción final" en la década de 1960}

Durante la década de 1960, la mayor parte de los miembros de la Nueva Dogmática Chilena adoptan la "teoría de la acción final" como punto de partida para sus contribuciones dogmáticas: Alfredo Etcheberry fundamenta en ella su rechazo a la teoría de la equivalencia de las condiciones y su reemplazo por la de la "causalidad de la voluntad", entendiendo equivalentes las ideas de "voluntariedad" y "finalidad",; Enrique Cury, su concepto de conducta "con sentido", como la que "abarca tanto el lado objetivo como el subjetivo de la acción, tanto su faz interna como externa"; ${ }^{156}$ Juan Bustos, su interpretación de la voz "voluntaria" del artículo $1^{\circ}$ del Código penal como "culpabilidad en sentido restringido", llevando el dolo y la culpa al concepto mismo de "acción"; ${ }^{157}$ y Luis Ortiz Q., su interpretación del Código penal como confirmación de

en los delitos de falsedad documental", pp. 33-66; y "El objeto material de la falsedad documental: Documentos y sus clases", pp. 219-240)

${ }^{154}$ La primera contribución original de la Nueva Dogmática Chilena apareció en la Revista de Ciencias Penales el año 1956, y se trataba de un capítulo de la Memoria de Prueba de Sergio POLITOFF L., titulado "Prenda, Depósito y Mandato en la Teoría de la Apropiación Indebida" (Revista de Ciencias Penales, T. XVI (1956), pp. 9-50). Como su título lo indica, no se trataba de un texto que abordase aspectos de la teoría del delito en particular, pero su lectura muestra la enorme calidad del trabajo de su autor: con importante aparato bibliográfico da cuenta del contenido de las instituciones civiles mencionadas para relacionarlo con el delito de apropiación indebida y sus diferencias con las figuras especiales de "hurto del dueño" que se encuentran en su órbita, a la luz de su larga evolución histórica.

${ }^{155} \mathrm{Su}$ primer aporte en este sentido se encuentra en el texto "Reflexiones críticas sobre la Relación de Causalidad", Revista de Ciencias Penales, T. XVIII (1959), pp. 175-200. Etcheberry afirma aquí expresamente su rechazo al concepto "causal" de v. Liszt, basado en la teoría de la equivalencia de las condiciones, con el argumento de que estaría anclado a un "dogma" "naturalista". Para Etcheberry, "la causa de los delitos es la voluntad humana" que se pone en movimiento y se vincula al resultado producido, y por lo tanto, sólo sería "causa" lo "objetivamente previsible" para esa voluntad. Sin variaciones, este concepto de "causa de la voluntad" es sostenido todavía por Etcheberry en la última edición de su Derecho penal (ETCHEBERRY, Alfredo, Derecho penal, parte general, T. I, $3^{a}$ ed., Santiago: Ed. Jurídica, 1997, pp. 184-188).

${ }^{156}$ CURY, Enrique, "La ausencia de tipicidad en el Código penal", Revista de Ciencias Penales, T. XIX (1960), pp. 51-57, p. 56. Más adelante publicaría Cury su aportación a la discusión acerca de "La teoría del principio de ejecución en la tentativa" (T. XXII (1963), pp. 167-195), donde, a contrapelo de su tendencia finalista estricta, aborda la cuestión desde el punto de vista de la doctrina italiana (que cita profusamente), para terminar afirmando su preferencia por la "teoría objetivo formal" (p. 194) y no por alguna subjetiva, como era lo esperable (y es la que acepta hoy en día en la última edición de su Derecho penal, parte general [Santiago: Ed. U. Católica de Chile, 2005, p. 559s], basada en "el plan individual del autor", aunque "limitada" por "criterios objetivos", que remiten de nuevo a la teoría "objetivo formal"). Antes, el año 1958, publicó un artículo sobre "Interpretación del artículo 343 del Código penal", donde desarrolla la tesis que ha sostenido hasta hoy en día acerca del carácter "cuasidelictual" y no "preterintencional" del delito de aborto del artículo 343 del Código penal. Para ello se basaba en la inexistencia entre nosotros de una figura de "violencias" sin causar lesiones, que sería el "delito doloso" si fuese el artículo 343 del Código una figura preterintencional (Revista de Ciencias Penales, T. XVII (1958), No 3, pp. 86-91. Con todo, en la última edición de su Derecho penal, cit., p. 344, califica su afirmación de 1968 como "discutible".

${ }^{157}$ BUSTOS, Juan; SOTO, Eduardo, "Voluntaria significa culpabilidad en sentido restringido", Revista de Ciencias Penales, T. XXIII (1964), pp. 243-264. La consecuencia de este nuevo concepto de "voluntariedad" sería que la "presunción" simplemente legal de ésta, que se encuentra en el inciso segundo de ese artículo no podría referirse al "dolo", sino únicamente al hecho de ser el sujeto imputable 


\section{MATUS, Jean Pierre "Origen, consolidación y vigencia de la Nueva Dogmática Chilena (ca. 1955 1970)"}

que el dolo pertenece a la acción y no a la culpabilidad, y de que debe aceptarse la exigencia general de los "elementos subjetivos de las causas de justificación". ${ }^{158}$ Mucho después, también Sergio Yáñez dejaría por escrito su convencimiento arrastrado desde esta época de que "la esencia del actuar humano es precisamente que los cursos causales son guiados, determinados desde un fin propuesto" y que el sistema finalista es el más adecuado para el análisis del delito. ${ }^{159}$

En cambio, Jaime Vivanco acepta sin discusión la última versión de la "Teoría del Delito-tipo" de Beling para desarrollar su estudio sobre el delito de "robo con homicidio" como "delito complejo" en que la muerte está subjetivamente vinculada con la apropiación. ${ }^{160}$ Por su parte, Miguel Schweitzer W., discurre dentro del "sistema neoclásico" cuando, contra la entonces doctrina dominante, afirmaba el valor excluyente del dolo del "error de Derecho", sin entrar en mayores cuestionamientos sistemáticos. ${ }^{161}$ Este mismo estilo adopta Grisolía, quien parece optar por no participar del enfrentamiento sistemático, aunque, al analizar ciertos delitos en particular, un par de décadas después, se muestra más bien distante con "el finalismo alemán". ${ }^{162}$

En esta época, sólo Politoff afirma derechamente el valor del punto de vista "neoclásico" y se plantea contra la corriente "finalista". En primer lugar, descarta que del hecho de que en ciertos casos se exija legalmente un "elemento subjetivo" para afirmar una causal de justificación deba deducirse que éstos son exigibles en todas las justificantes, pues eso, recogiendo la opinión de Novoa, "conduce a la confusión de la Moral con el Derecho". Y, en segundo término, rechaza también que la aceptación de la existencia de "elementos subjetivos" en algunos tipos penales conduzca necesariamente a aceptar que a todos los tipos pertenecería como elemento subjetivo un "dolo" "neutral" y "avalorado", pues -y aquí se cita a Jiménez de Asúa- "lo que conduce la

\footnotetext{
y a su conocimiento de la antijuridicidad del hecho, esto es, a la "culpabilidad en sentido restringido" y, en consecuencia, "cabrá alegar la ignorancia o el error sobre la antijuridicidad y habrá de admitirse la prueba correspondiente". Soto, entonces ayudante de Bustos, no siguió la carrera académica en el Derecho penal.

${ }^{158}$ ORTIZ Q., “Algunas consideraciones...”, cit. nota al pie n 122. Ahora, 45 años después, Luis Ortiz Q. volvería el camino recorrido para afirmar que estas interpretaciones suyas de juventud eran una "acomodación que hace artificialmente compatible la tesis de la acción finalista con el texto del Código", y que el dolo pertenece a la culpabilidad como reproche y sólo puede ser entendido como "malicia" (esto es, con "conocimiento del injusto"), por lo que tanto el error de tipo como el de prohibición han de seguir una misma regulación: exclusión del dolo y la culpa, en caso de ser inevitable; exclusión del dolo y subsistencia de la culpa, en caso de ser evitable (ORTIZ Q., Luis, "Dolo y conciencia del injusto en la ley penal chilena”, en SCHWEITZER W., Nullum crimen, cit. nota al pie no 11, pp. 279-294).

${ }^{159}$ YÁÑEZ, Sergio, "La evolución del sistema del Derecho penal", Cuadernos de Política Criminal, No 54 (1994), pp. 1153-1209, p. 1193.

${ }^{160}$ VIVANCO, El delito de robo con homicidio, cit. nota al pie $\mathrm{n}^{\mathrm{o}} 133$, p. 64.

${ }^{161}$ SCHWEITZER W., "El error", cit. nota al pie n' 139. En 1967 publicó un artículo "Sobre los delitos de la Ley de Quiebras" (Revista de Ciencias Penales, T. XXVI (1967), pp. 151-161), con similar estilo y la colaboración del "neoclásico" Sergio Politoff.

${ }^{162}$ Así, en "La estafa procesal” (Revista Chilena de Derecho, Vol. 24, No 3 (1997), pp. 417-422, p. 422), escribe: "el dolo -aun en la doctrina finalista-..."; y en "El delito de asociación ilícita" (Revista Chilena de Derecho, Vol. 31, № 1 (2004), pp. 75-88, p. 83), siguiendo la doctrina italiana, habla del dolo como "elemento psíquico" del delito, y agrega: "No es el momento de entrar en la distinción de finalidad y dolo, propia del finalismo alemán...”). En su primer artículo (y a la vez su Memoria de Grado, ver nota al pie No 135), el "El objeto jurídico del delito", Revista de Ciencias Penales, T. XVII (1958), No 3, pp. 385, Grisolía sólo cita en dos ocasiones a Welzel (notas al pie 192 y 214), sin hacerse cargo del carácter secundario que éste asigna a los bienes jurídicos como objeto de protección del Derecho penal.
} 
Polit. crim. Vol. 6, № 11 (Julio 2011), Art. 3, pp. 44 - 105.

[http://www.politicacriminal.cl/Vol_06/n_11/Vol6N11A3.pdf]

intención a la categoría del dolo es el juicio de culpabilidad, de suerte que el dolo es un concepto normativo". 163

\subsubsection{Evolución posterior: las obras generales de la Nueva Dogmática Chilena}

Con el pasar de los años, Etcheberry, Cury, Bustos y Politoff se dieron a la tarea de sistematizar sus opiniones en textos generales.

Y si se analizan estos textos, podrá verse cómo únicamente Cury mantiene la ortodoxia del "sistema finalista"; mientras Etcheberry, aceptando en principio la idea de la "acción final" como adecuada para describir los hechos constitutivos de delito, no acepta, en cambio, sus consecuencias sistemáticas, adoptando esencialmente un esquema de exposición "neoclásico".

Por su parte, y tras su paso por el exilio y el contacto con la dogmática de Holanda y España, donde ejercieron la Cátedra de Derecho penal, Politoff y Bustos presentan una evolución en su pensamiento, particularmente respecto de los fundamentos y criterios de legitimación del Derecho penal, sin que ello, no obstante, modifique sus planteamientos sistemáticos, que se mantienenen en las tendencias "neoclásica"y "finalista" (o más bien "postfinalista"), respectivamente.

Dada la importancia de estos autores para el Derecho penal chileno, cuyos textos generales, tras múltiples ediciones, todavía circulan entre nosotros y se emplean en la enseñanza universitaria y la práctica forense, haremos en este lugar una breve reseña de sus planeamientos, respetando el orden de aparición de la primera edición de la respectiva obra general.

a) El "finalismo matizado" de Alfredo Etcheberry $O{ }^{164}$

En la primera edición de su Derecho penal, el año 1964, define Etcheberry delito como "acción típicamente antijurídica y culpable", enfatizando que la "acción" es el único sustantivo y que "las demás voces indican sólo cualidades o modos de ser de la acción". De allí que, en su concepto, "no es, por lo tanto, correcto emplear la expresión "elementos" del delito para referirse en un mismo plano, a la acción, la tipicidad, la

\footnotetext{
${ }^{163}$ POLITOFF, Elementos subjetivos, cit. nota al pie no 140 , pp. 59 y 80.

${ }^{164}$ Alfredo Etcheberry empezó su carrera académica como Ayudante Investigador del Seminario de Derecho Penal y Medicina Legal de la Universidad de Chile entre 1957 a 1962 . El año 1962 obtuvo el nombramiento de Profesor Ordinario (Anales de la Facultad de Ciencias Jurídicas y Sociales, Cuarta Época, Vol. III (1961-1963), No 3, p. 156); y el 1964, el de Profesor Extraordinario (Anales de la Facultad de Ciencias Jurídicas y Sociales, Cuarta Época, Vol. IV (1965-1965), No 4, p. 79). Dirigió la Revista de Ciencias Penales desde 1960 hasta 1966, y ha sido miembro del Directorio y Presidente (en la actualidad) del Instituto de Ciencias Penales. Fue Presidente del Foro Penal para la redacción de un Anteproyecto de Código Penal, entre 2002 y 2004. Ha ejercido ininterrumpidamente la profesión de abogado, desde su titulación y hasta el presente. Por su contribución al Derecho penal, se le otorgó el título de Doctor Honoris Causa por la Universidad de Talca el año 2008. Actualmente es Profesor Titular del Departamento de Ciencias Penales, acogido a jubilación.

Entre sus últimas publicaciones, aparte de las que se citan en el texto, se encuentran aportes a la discusión acerca "La Corte penal internacional - Jurisdicción, estructura, funcionamiento" (Revista de Derecho [U. Católica Concepción], No 10 (2002), p. 551), "El foro penal y el sistema de penas" (Revista de Derecho [Coquimbo], No 9 (2002), pp. 7-25) y "Reflexiones sobre Política Criminal”, Política Criminal, Vol. 4, $\mathrm{N}^{\mathrm{o}} 7$ (2009), D2, pp. 235-249. Un listado de sus publicaciones en revistas chilenas hasta el año 2003 puede verse en MATUS / CARNEVALI, “Análisis...", cit. nota al pie nº 11, pp. 41 y ss.
} 
antijuridicidad y la culpabilidad", en clara alusión contraria al modelo de Novoa. En este texto también concibe la acción de manera finalista, como "todo comportamiento humano dirigido por la voluntad con miras a un fin".

Sin embargo, sólo hasta este punto parece llegar el "finalismo" de Etcheberry, pues de los conceptos de delito y acción no deriva consecuencias sistemáticas, siguiendo más bien una variante del modelo "neoclásico".

En efecto, en cuanto a la ubicación del dolo, afirma que, "si llamamos dolo a la voluntad ya valorada conforme a la reprochabilidad, no hay inconvenientes en reservar el dolo a la teoría de la culpabilidad": "la voluntad pertenece a la acción. Pero para llamar dolo a esa voluntad, debemos previamente valorarla, y esta valoración es precisamente el juicio de reproche o de culpabilidad". Tampoco acepta el carácter subjetivo de las justificaciones: concibe explícitamente la "antijuridicidad" como "valoración objetiva de la acción" y afirma: "nunca el orden jurídico hace depender la ilicitud de una conducta del propósito o intención del agente, si no va acompañado de la efectiva concurrencia de las circunstancias respectivas, factor este último que es el que verdaderamente justifica la acción". Y, finalmente, tampoco acepta la distinción de consecuencias entre "error de tipo" y "error de prohibición" (que limita a la "justificante putativa"), entendiendo en ambos casos que se excluye "el dolo" (salvo que sea "error de Derecho"). ${ }^{165}$

En las siguientes ediciones de su obra, Etcheberry, y salvo en cuanto al tratamiento del error, no ha variado esencialmente sus puntos de partida y sistematización, pero sí se ha hecho cargo del reproche de lo aparentemente "contradictorio" de su "singular actitud" frente al finalismo que se le hiciera en su oportunidad. ${ }^{166} \mathrm{Al}$ respecto, Etcheberry no ve contradicción alguna sino, al contrario, estima necesario admitir que "la voluntad finalista pertenece a la acción, pero que en cuanto tal carece de valoración; una vez valorada, calificada como reprochable, pasamos a llamarla dolo", por lo que rechaza la crítica y mantiene su sistemática. ${ }^{167}$

Es más, profundiza en la argumentación que lleva a considerar la antijuridicidad de la conducta como una valoración puramente objetiva de ésta, rechazando que las causas de justificación exijan, por regla general, un elemento subjetivo. Al respecto, afirma que no puede considerarse "antijurídico" un hecho que cumple con la finalidad de la ley (que se cumpla el deber, que se defienda a una persona o que se eviten males mayores) por la sola posición subjetiva del que lo ejecuta: "de lo contrario, estaríamos transformando la conformidad con el derecho en un premio a la virtud". Y en cuanto al tratamiento del error, mantiene su postura inicial de que todo error excluye el dolo, con independencia de su clase, incluyendo ahora también al "error de derecho". 168

\footnotetext{
${ }^{165}$ ETCHEBERRY, Alfredo, Derecho penal, T. I., Santiago: Gibbs, 1964, pp. 151, 161, 209, 216,255 y 307. Esta obra se publicó en cuatro tomos, abarcando toda la Parte General y la mayoría de los delitos de relevancia que deben incorporarse a una Parte Especial.

${ }^{166}$ RIVACOBA Y RIVACOBA, Manuel de, "El principio de culpabilidad en el Código penal chileno", en del mismo (ed.), Actas de las Jornadas Internacionales de Derecho penal en celebración del centenario del Código penal Chileno, Valparaíso: Edeval, 1974, pp. 49-126, p. 60, y nota al pie $\mathrm{N}^{\mathrm{o}} 52$, donde se afirma que la crítica ya estaría en un texto anterior de Zaffaroni, que no he podido consultar.

${ }^{167}$ ETCHEBERRY, Alfredo, Derecho penal, T. I., $3^{a}$ ed., Santiago: Ed. Jurídica, 1997, p. 275.

168 Íd., pp. 229, 235 y ss, y 334 y ss.
} 
Polit. crim. Vol. 6, № 11 (Julio 2011), Art. 3, pp. 44 - 105.

[http://www.politicacriminal.cl/Vol_06/n_11/Vol6N11A3.pdf]

b) El "finalismo ortodoxo" de Enrique Cury $U^{169}$

En 1969 Cury publica su Orientación para el estudio de la Teoría del Delito, primer texto de carácter general del autor. Aquí se desarrolla, con relación al Derecho chileno, la teoría final de la acción, siguiendo rigorosamente la sistemática de los textos ya disponibles de Welzel y Maurach. Por el rigor finalista de Cury en esta época acepta la teoría extrema de la culpabilidad y sus efectos penales respecto del error de prohibición (excusabilidad en caso de ser invencible, mera atenuación en caso de ser vencible, incluso en los supuestos de error sobre los presupuestos objetivos de una causal de justificación), por considerarla "una consecuencia necesaria de la concepción final de la acción". ${ }^{170}$

Esta es la misma concepción y sistemática que Cury mantiene hasta la fecha en la edición de 2005 de su Derecho penal donde se afirma que "el concepto de acción finalista ... servirá de base al sistema de la teoría del delito que se expondrá en esta obra", con la sola salvedad de rechazar ahora la teoría estricta de la culpabilidad y admitir, en cambio, la limitada, lo que le lleva a considerar el error sobre los presupuestos objetivos de una causal de justificación como "un error de prohibición que, no obstante, por razones de justicia material debe ser tratado como si fuera un error de tipo con consideración a que, lo mismo que este último, supone una adhesión del autor a los dictados del derecho". 171

\footnotetext{
${ }^{169}$ Enrique Cury U. inició su carrera académica como Profesor de la Universidad Católica de Chile y de la entonces Sede Valparaíso de la Universidad de Chile. Fue nombrado Profesor de Derecho Penal Suplente en la Universidad de Chile (Santiago), el año 1972 (Anales de la Facultad de Ciencias Jurídicas y Sociales, Cuarta Época, Vol. XIII, (1972), No 13, p. 51. En la Universidad Católica ha desempeñado los cargos de Director General de la Vicerrectoría Académica y Secretario general. Fue Presidente del Foro Penal (sucediendo a Etcheberry en el cargo) hasta la entrega al Gobierno, a fines de 2005, del Anteproyecto de Nuevo Código Penal. Ministro de la Corte Suprema desde 1998 hasta 2006, como tal redactó una sentencia reconociendo el efecto excluyente de la culpabilidad del "error de prohibición" (SCS 4.8.1998), que ha sido calificada de "histórica" (Soto, Miguel, "Una jurisprudencia histórica: hacia el reconocimiento del principio de culpabilidad en el Derecho penal chileno", Revista de Derecho U. Finis Terrae, N 3 (1999), pp. 233-253). Por su destacada trayectoria e influencia, obtuvo el año 2010 el título de Dr. Honoris Causa por la Universidad de Valparaíso, sucesora legal de la Sede donde comenzó su carrera. Actualmente es Profesor de la P. Universidad Católica de Chile. Aparte de los textos que aquí hemos citado, a partir del año 1970, Cury ha escrito casi una veintena de artículos de los más variados temas, sin dejar de lado su punto de vista "finalista", de importancia e impacto en la práctica forense, como su "Contribución al estudio de la responsabilidad médica por hechos culposos" (Revista de Ciencias Penales, T. XXXVII (1978-1981), pp. 97-10) y "El concepto de autor mediato como categoría imprescindible en la interpretación de la ley penal chilena" (Revista Chilena de Derecho, Vol. XII (1985), pp. 35-53). Una lista relativamente completa de sus contribuciones hasta el año 2006 puede verse en MATUS / CARNEVALI, “Análisis...,", cit. nota al pie n 11, p. 38.

${ }^{170}$ CURY U., Enrique, Orientación para el estudio de la Teoría del Delito, Valparaíso: Edeval, 1969, pp. 214-220, lo entrecomillas, en p. 217.

${ }^{171}$ CURY, Derecho penal, cit. nota al pie no 156 . Lo entrecomillado en pp. 263 y 448.
} 
c) Del "finalismo" al "postfinalismo" en Juan Bustos R.: revalorización del bien jurídico en el "injusto" dentro de un "sistema crítico" con base "finalista" 172

En 1974, cuando comenzaba su exilio, Juan Bustos publicó su artículo "Consideraciones en torno al injusto". En este texto sienta las bases de su aproximación personal al concepto del delito, a partir de su formación en la sistemática finalista: rechaza el "concepto causal" de "desvalor de resultado" como medida de "lo injusto" ("la sustancia de lo punible"), pues llevaría a considerar como tal casos de responsabilidad objetiva ("delitos calificados por el resultado" y el versari in re ilícita); pero, aceptando el "concepto personal" del injusto finalista (y sus consecuencias sistemáticas en orden a la ubicación del dolo y el contenido de la culpabilidad, que permitirían excluir la responsabilidad objetiva), estima que no pueden aceptarse también sus consecuencias respecto a la punibilidad de la tentativa inidónea y la eventual insignificancia del resultado incluso en los delitos dolosos, basadas en la consideración del "desvalor de acto" como único fundamento de "lo injusto". Para salir de este dilema propone, en primer lugar, revalorizar la función del bien jurídico en el contenido del injusto:

\begin{abstract}
"Al derecho penal lo que le interesa proteger no son los buenos ánimos de las personas, sino los bienes vitales para la subsistencia de esa sociedad, esto es, los bienes jurídicos...Lo injusto es, por tanto, ante todo una materialización de la protección de los bienes jurídicos por parte del ordenamiento jurídico, $\mathrm{y}$ en esa medida es que impone penas."
\end{abstract}

\footnotetext{
${ }^{172} \mathrm{Su}$ memoria, Concurso ideal de delitos (Santiago: Ed. Universitaria, 1962), fue informada por Etcheberry y Labatut con la nota máxima. Allí adopta la teoría final de la acción para interpretar el artículo 75 del Código penal (p. 13) y da cuenta de la discusión alemana acerca de la "unidad de acción", sin dejar de citar a los italianos y la propuesta del sistema "clásico". Además, durante la década de 1960 publica en Chile una importante monografía sobre delitos culposos derivada de su tesis alemana (Culpa y finalidad. Los delitos culposos y la teoría final de la acción, Santiago: Ed. Jurídica de Chile, 1967); su traducción -en conjunto con Sergio Yáñez- de la $11^{\mathrm{a}}$ ed. del Derecho penal alemán de Hans WELZEL (Santiago, Ed. Jurídica de Chile, 1969), amén de otros significativos artículos en la Revista de Ciencias Penales que aquí se citan. Ayudante investigador desde 1965 en el Seminario de Derecho Penal y Medicina Legal de la Universidad de Chile, en 1966 comienza su carrera docente como Profesor en la Sede de Valparaíso de la Universidad de Chile, donde en 1970 obtiene por concurso el cargo de "Profesor agregado Derecho penal, ad-honorem" (Anales de la Facultad de Ciencias Jurídicas y Sociales, Cuarta Época, Vol. XI (1970), $\mathrm{N}^{\mathrm{o}}$ 11, p. 163) y, por la ausencia del electo Director del recién creado del Departamento de Ciencias Penales, Álvaro Bunster, asume el cargo hasta 1973. Fue Secretario de Redacción de la Revista de Ciencias Penales desde el año 1967 hasta 1973. Siguiendo el designio de Novoa y Politoff, parte al exilio tras el Golpe de Estado. Detenido en Argentina en la "Operación Cóndor", es liberado gracias a la intervención del profesor Armin Kaufmann y las autoridades alemanas. Se le concede la beca Alexander von Humboldt y, después de unos años, llega a España, en 1982, donde desarrollaría una gran carrera académica, al punto de obtener la Cátedra de Derecho Penal en la U. Autónoma de Barcelona. Esta es su época más prolífica y original en cuanto a su visión del Derecho penal, y sobre ella se expondrá más adelante, arriba en el texto. Sus Obras Completas se han editado en Chile y Perú en tres extensos volúmenes. A su regreso a Chile, en 1992, se incorporó tanto al ejercicio profesional como a la vida universitaria en varias instituciones privadas y se le admitió nuevamente, ahora como Profesor Titular, en la Universidad de Chile. Sus últimos años los dedicó a la vida política de manera intensa, ejerciendo el cargo de Diputado desde el año 1997. Falleció el año 2008, siendo Presidente de la Cámara de Diputados. Para más detalles sobre su vida y obras, véase la "Nota Biográfica", en BUSTOS, Juan, Obras Completas, Tomo I, Lima: Ara Eds., 2004, pp. 45-49, y la reseña "bio-bibliográfica" del sitio del Congreso http://biografias.bcn.cl/wiki/Juan José BUSTOS Ramírez [visitado el 1.3.2011].
} 
Polit. crim. Vol. 6, № 11 (Julio 2011), Art. 3, pp. 44 - 105.

[http://www.politicacriminal.cl/Vol_06/n_11/Vol6N11A3.pdf]

En segundo término, para darle sentido a esta afirmación, propone analizar "críticamente" la configuración normativa para determinar el concepto "material" de "bien jurídico" subyacente, observando que en ella

"valor o desvalor, no son en realidad de acto o de resultado desde un punto de vista material, sino de relación social o posición que el individuo ocupa [en la sociedad] ... sólo la consideracióndel desvalor o valor de la relación social nos puede dar una adecuada visión de injusto, esto es, una apreciación crítica, y sólo de esa manera podemos dar una adecuada explicación de un sistema penal o construir un sistema penal cualquiera, que pretenda de una u otra manera captar una cierta realidad histórica social. "173

La cuestión de si ese desvalor o valor de la relación social es inmanente a las reglas jurídicas, y por tanto, sólo utilizable como un dato para una crítica externa; o es extrínseco a ellas, y por lo tanto, susceptible de emplearse para fundamentar su crítica e interpretación, determinando si en un precepto en concreto puede reconocerse o no un "bien jurídico", para negar su legitimidad en caso de no contemplarlo y, en caso afirmativo, darle contenidoy limitarlo, es resuelta por Bustos en este último sentido.

En efecto, afinando el concepto de "bien jurídico", Bustos sostendrá que éste "plasma" "de manera concreta ese complejo social que interesa proteger", por lo que sería "una fórmula sintética concreta de lo que se protege realmente", pero de la cual "no surge" su "significación y legitimidad", que estaría dada por las "relaciones sociales, las posiciones que en ellos ocupan los individuos, su interacción con las cosas y otros entes, y la interacción que se produce entre ellos." Por lo tanto,

\begin{abstract}
"Se trata no sólo de imponer dentro de un derecho garantizador que todo precepto punitivo debe tener un bien jurídico, y con ello partir de que hay preceptos punitivos que no lo tienen, que hay preceptos que su bien jurídico es tan mediato, confuso, vago y abstracto que, en realidad tampoco tienen bien jurídico sino también, que, frente a bienes jurídicos que cumplen con las características propias de una fórmula sintética de la relación social, indagar si realmente tal fórmula sintética es reflejo de la relación social actual o de lo que implica una relación social entre hombres, además indagar si el derecho ha recogido lo que surge de la relación social, si lo ha concretado en bienes jurídicos." ${ }^{\prime 17}$
\end{abstract}

\footnotetext{
${ }^{173}$ Y, en una actitud muy propia de la época, concluía que esta apreciación "crítica" del bien jurídico no tenía sólo la finalidad de "llegar a una concepción científica del derecho", sino ante todo, la de "constituirlo en una herramienta para las transformaciones sociales" (BUSTOS, Juan, "Consideraciones en torno al injusto", Nuevo Pensamiento Penal, Año 3(1974), p. 41ss. La versión que aquí se cita es la contenida en el extenso volumen recopilatorio (630 pp.) de los artículos de Juan BUSTOS, Control Social y Sistema Penal, Barcelona: PPU, 1987, pp. 141-157. Las citas literales son de las pp. 152, 155, 157). El aspecto "político" de las propuestas de Bustos, de innegable afiliación marxista, queda todavía más claro en su texto "Criminología crítica y Derecho penal", del año 1987: aquí se recurre a la criminología crítica (de afiliación marxista, también), para discutir la vigencia real de las "garantías formales" de igualdad en un sistema penal que operaría sobre la base de la discriminación por "etiquetamiento"; de la "responsabilidad" por el actuar "libre", en circunstancias que las reglas jurídicas responden a los intereses de las clases dominantes; y de la "justicia" del "reproche penal", en circunstancias que éste se haría sólo a "personas en conflicto social". Pero se va más allá y se critica también toda la "teoría de las normas", por esconder detrás de ella su génesis, y hacerlas aparecer como un producto metafísico o natural; lo mismo que las variantes sobre las teorías de las pena, que se ofrecerían como "ideologías" para "encubrir" que el delito es "expresión de conflicto social concreto y de falta de opciones o alternativas de superación" (en Control Social, cit., pp.15-29, la cita final es de la p. 26).

${ }^{174}$ BUSTOS, Juan, "Política criminal e injusto (Política criminal, bien jurídico, desvalor de acto y de
} 
De este modo, Bustos abandona la "teoría final de la acción" como fundamento del "injusto penal" y, por tanto, del sistema del Derecho penal y de la Teoría del Delito, reemplazándola por su propia "Teoría del Bien Jurídico", cuya originalidad es indiscutible. ${ }^{175}$

Así, en su Manual de Derecho penal, Bustos da por buenas las críticas al concepto "neoclásico" de delito en la versión de Mezger (la confusión de "elementos" "normativos" y "subjetivos" en una tipicidad aparentemente "objetiva", y la de elementos "psicológicos" -dolo y culpa- y "normativos" en la "culpabilidad"); pero también las que se dirigen a la "teoría final de la acción", afirmando que "la acción no es el concepto superior del sistema", pues, en primer lugar, existen los delitos de "omisión", "con una estructura completamente diferente e imposible de subsumir dentro de aquella"; en segundo término, "la culpabilidad no es un reproche a la acción, sino al sujeto en relación con sus capacidades de actuar"; y en tercero, porque a nivel de injusto "el comportamiento (acción u omisión) interesa en la medida en que puede ser atribuido en consideración al bien jurídico a un tipo determinado". Por lo tanto, concluye afirmando que "el concepto fundamental y vinculante para el injusto no es la acción sino el bien jurídico", que define ahora como "una fórmula normativa sintética concreta de una relación social determinada y dialéctica", y por eso, "el primer aspecto a considerar dentro del injusto tampoco es la acción, sino la tipicidad."

El delito ya no es, desde su punto de vista, una "acción u omisión típica, antijurídica y culpable", sino "lo injusto para el ordenamiento jurídico", cuyo "contenido está dado por la tipicidad y la antijuridicidad". Así, "la culpabilidad no es contenido del hecho ni del injusto y tampoco por tanto del delito", sino que está referida a "una determinación del sujeto responsable", esto es, a la "responsabilidad" del "sujeto respecto de su hecho", según "lo que puede exigir el sistema de una persona frente a una situación concreta". ${ }^{177}$

Hecha así la distinción entre "injusto" y "responsabilidad", Bustos plantea que, en cuanto a la "tipicidad", hay que concebirla como "la configuración en la realidad" de "la descripción de un ámbito situacional concreto". Como esos ámbitos son diferentes, según la clase de "comunicación social" involucrada, habría también que distinguir cuatro "estructuras del delito": delitos de comisión dolosa, delitos de comisión culposa, delitos de omisión dolosa y delitos de omisión culposa. Sin embargo, dentro de cada una de esas estructuras, "no resulta adecuado", para Bustos, mantener una estricta división entre la "faz objetiva" y la "faz subjetiva", pues ésta (proveniente del

resultado)", aparecido en Revue Internationale de Droit Penal (1978), en del mismo, Control Social, cit. nota al pie $n^{\circ} 173$, pp. 159-180, la extensa cita literal es de la p. 167.

${ }^{175}$ Para apreciar esta constatación, véanse las concepciones actuales de la discusión sobre el "bien jurídico", resumidas en ABANTO, Manuel, "Acerca de la teoría de los bienes jurídicos", en Urquizo, José (Dir.), Modernas tendencias de dogmática penal y política criminal. Libro homenaje al Dr. Juan Bustos Ramírez, Lima: Idemsa, 2007, pp. 1-78.

${ }^{176}$ BUSTOS, Juan, Manual de Derecho penal. Parte general, $3^{a}$ ed., Barcelona: Ariel 1989, pp. 143-146, 151, 155. La definición de bien jurídico es algo más precisa en su formulación que la antes transcrita, ya que incorpora en un solo concepto la distinción entre "formulación" y "legitimidad" de las versiones anteriores. Se usa esta edición pues es la última en que BUSTOS interviene como autor de manera exclusiva. En las siguientes aparece como colaborador y coautor Hernán Hormazábal. La última colaboración entre ambos, como texto general son sus Lecciones de Derecho Penal, Madrid: Trotta, 2006. ${ }^{177}$ Íd., pp. 155, 325. 
Polit. crim. Vol. 6, № 11 (Julio 2011), Art. 3, pp. 44 - 105.

[http://www.politicacriminal.cl/Vol_06/n_11/Vol6N11A3.pdf]

finalismo) "olvida" que la tipicidad "es una unidad de sentido y que la distinción en elementos descriptivos, normativos y subjetivos, sólo tiene por objetivo poner acento en los problemas especiales que surgen desde estas perspectivas". ${ }^{178}$

En cuanto a la "antijuridicidad", la entiende como "la contravención del hecho típico con todo el ordenamiento jurídico en virtud de una afectación efectiva del bien jurídico", lo que supone considerar en este nivel no sólo la "formal" ausencia de causas de justificación, sino también el "material" "desvalor de resultado". ${ }^{179}$

Finalmente, cabe señalar que, en lo que respecta a la estructura del delito debe entenderse lo siguiente: se distingue entre "injusto" y "culpabilidad". El "injusto" no presenta una estructura unitaria, sino tres, claramente diferenciadas: "delitos dolosos de acción", "delitos dolosos de omisión", "delitos culposos"; y la "culpabilidad", que pasa a denominarse "teoría de la responsabilidad", se refiere exclusivamente a las condiciones en que se responde penalmente del injusto.

La originalidad del fundamento y planteamiento sistemático de Bustos no alcanza, sin embargo, a cuestionar ciertos aspectos sistemáticos fundamentales que se consideraban "una consecuencia" de la adopción de la "teoría final de la acción", esto es, la ubicación del dolo y la culpa en la tipicidad (y como estructuras diferenciadas) y la exigencia de "elementos subjetivos en las causas de justificación". ${ }^{180}$ En cambio, por su consideración del "injusto" como "uno sólo" y precisamente por incluir en éste los "elementos subjetivos de las causales de justificación", estima Bustos que el error sobre el sentido o los presupuestos fácticos de una causal de justificación debe considerarse como un "error esencial" "sobre un elemento de la infracción penal" (esto es, básicamente, como un "error de tipo" en la nomenclatura tradicional), excluyendo, por tanto, el "error de prohibición" del tratamiento de la "culpabilidad" ("responsabilidad"). ${ }^{181}$

Es por ello que, propiamente, Bustos es el único penalista de la Nueva Dogmática Chilena que puede considerarse "postfinalista", al abandonar tanto el "sistema neoclásico" como la "teoría de la acción final" como presupuesto del "sistema", manteniendo, sin embargo, buena parte de las consecuencias sistemáticas del sistema de Welzel, esto es, su configuración externa como método analítico.

\footnotetext{
178 Íd., pp. 158 y ss.

179 Íd., p. 161.

180 Íd., p. 210 . Bustos habla de la exigencia de acreditar una "motivación intencional" de preservar bienes jurídicos y de contribuir "al mantenimiento del orden jurídico".

${ }^{181}$ Íd., pp. 260 y ss.
} 


\section{d) El "sistema neoclásico con mesura" de Sergio Politoff L. ${ }^{182}$}

Como ya hemos señalado, en la década de 1960 Sergio Politoff enfrentó por primera vez la discusión entre el "sistema neoclásico" y el derivado de la "teoría final de la acción", decantándose por el primero con el argumento de que la "teoría final de la acción" llevaba ínsito un concepto de "injusto personal" que tendencialmente conducía a la sanción por la sola disposición anímica contraria al Derecho, como paradigmáticamente se afirma respecto de la tentativa inidónea y la exigencia de los elementos subjetivos en las causales de justificación, esto es, a un Derecho penal del "carácter" o de "autor". 183

Esta es la misma posición que, en términos generales, sostiene en su Derecho penal, cuya primera edición se publicó el año 1997, aunque ahora reforzada por el conocimiento de los textos originales en los cuales Welzel desarrolló su teoría, durante el régimen nacionalsocialista. No son, por tanto, razones de orden "didáctico" o de

\footnotetext{
${ }^{182}$ Ayudante Investigador del Seminario de Derecho Penal y Medicina Legal de la Universidad de Chile desde 1963. Su Memoria de Grado aparece publicada el año 1957 (El delito de apropiación indebida, cit. notal al pie $\mathrm{n}^{\mathrm{o}}$ 131). Luego, viaja a Italia donde obtiene su Diploma de Especialización en Derecho Penal en la Universidad de Roma, con una tesis que, traducida al castellano, será publicada en Chile bajo el título Los elementos subjetivos del delito (cit. nota al pie $\mathrm{n}^{\circ} 140$ ), trabajo con el que obtuvo el título de Profesor Extraordinario en la Universidad de Chile, el 5 de agosto de 1965 (Anales de la Facultad de Ciencias Jurídicas y Sociales, Cuarta Época, Vol. VI (1966), No 6, p. 110). El año 1966 apareció el artículo "Omisión de socorro y homicidio por omisión" donde se plantea la configuración de los delitos de omisión impropia sobre la base exclusiva de su carácter "normativo" e introduce en Chile la exigencia de la "posición de garante" ("ley" y "contrato") como fundamento de su castigo (Revista de Ciencias Penales, T. XXV (1966), pp. 163-185. Aunque el artículo aparece suscrito también por Juan BUSTOS y Claudio FLISFISCH, la sistemática y estilo empleados son fuertes razones para creer que su concepción y redacción corresponden a Politoff y que los dos restantes colaboraron de manera indirecta). Además, en la misma década de 1960 publica varias notas jurisprudenciales y bibliográficas en la Revista de Ciencias Penales y, a principios de 1970, da a conocer entre nosotros "El nuevo Código penal de la República Democrática Alemana" (Revista de Ciencias Penales, T. XXIX (1970), pp. 3-14). Tras ello publica su Derecho Penal chileno, parte especial, cit. nota al pie $\mathrm{n}^{\circ} 4$. En la portada del libro aparecen también como coautores Juan BUSTOS y Francisco GRISOLÍA. Sin embargo, ellos sólo fueron colaboradores en la revisión de los textos que Sergio Politoff redactaba, según mis conocimientos de primera fuente y lo que resulta del simple cotejo de la obra con el estilo y sistemática de Politoff y sus colaboradores. En esta época Politoff ejerció activamente la profesión y, como Novoa, apoyó al Gobierno de Salvador Allende, ejerciendo como asesor en el Ministerio del Interior. El Golpe de Estado de 1973 lo deja en el exilio, donde tras un periplo entre Leipzig y Ginebra, recala en Rotterdam, cuya Universidad lo recibe como Profesor. Allí enseña hasta su jubilación (1994) y publica una docena de artículos en varios idiomas, referidos principalmente a la situación de los derechos humanos en Chile. De regreso a Chile, entre 1995 y 1999 enseña Derecho penal en la Universidad de Talca, como Profesor Titular, y desde allí publica no sólo su Parte General, ya citada, sino también un texto sobre iter criminis (Los actos preparatorios del delito tentativa y frustración: estudio de dogmática penal y de derecho penal comparado, Santiago: Ed. Jurídica, 1999), y varios artículos y libros recopilatorios sobre el delito de tráfico ilícito de estupefacientes (El último de ellos coeditado con JP MATUS, fue Lavado de dinero y tráfico ilícito de estupefacientes, Santiago: LexisNexis, 1999). Sergio Politoff vuelve a Europa el año 2000 y, aprovechando los actuales medios electrónicos, mantiene una intensa colaboración con el autor de este texto y la Prof. $\mathrm{M}^{\mathrm{a}}$ Cecilia Ramírez G., la que se traduce en las Lecciones de Derecho Penal Chileno que se publican en 2004 (Parte General) y 2005 (Parte Especial). En Holanda traduce el Tratado de M.E. MAYER y sigue publicando artículos, como su "Obediencia y delito en contextos cambiantes" (en El penalista liberal, cit. nota al pie $n^{\circ} 38$, pp. 481-514). Fallece el 26 de diciembre de 2009. Más detalles sobre su vida y obra, véanse en GUZMÁN DALBORA, José Luis, "Estudio Necrológico: Sergio Politoff Lifschitz o la Perseverancia Creadora de una Vida Inmigrante," Política Criminal, Vol. 5, No 9, (Julio 2010), Doc. 1, pp. 257-276, [http://www.politicacriminal.cl/Vol 05/n_09/Vol5N9D1.pdf].

${ }^{183}$ Supra, nota al pie $\mathrm{n}^{\circ} 163$ y el texto a que hace referencia.
} 
Polit. crim. Vol. 6, № 11 (Julio 2011), Art. 3, pp. 44 - 105.

[http://www.politicacriminal.cl/Vol_06/n_11/Vol6N11A3.pdf]

"pureza del sistema", como las planteadas por Novoa, ${ }^{184}$ las que esgrime para rechazar la "teoría final de la acción" como fundamento del sistema penal y sus consecuencias sistemáticas, sino de carácter político criminal de fondo.

En consecuencia, en la última edición de su Derecho penal, afirma Politoff que la "teoría final de la acción" debe rechazarse porque "es en realidad una teoría final del injusto", donde lo que se castiga es "la pérdida del credo jurídico que nos impone el Estado en una determinada situación histórica". Por lo tanto, rechazado el fundamento del "sistema finalista", no ve razón para adoptar sus consecuencias sistemáticas, ofreciendo una exposición de la teoría del delito que puede, externamente, inscribirse en el molde del "sistema neoclásico". Para ello, toma en cuenta, además, que a la fecha de publicación de su texto, existían en Holanda, Italia y Alemania exposiciones sistemáticas que también seguían el esquema "neoclásico", aún después del fulgor del sistema finalista y que, respecto a la posición del dolo, la discusión ya había amainado tanto (precisamente por el abandono generalizado en Alemania de la "teoría final de la acción") que un autor se permitía señalar que el asunto bien podría someterse "a votación", indicando con ello a las claras que ya no existía ninguna razón "ontológica" que hiciera necesaria la adopción de la sistemática finalista. ${ }^{185}$

Esta es la diferencia esencial entrela postura de Politoff y los denominados postfinalistas, que, como Bustos también rechazan la "teoría final de la acción" como fundamento del sistema, pero mantienen, con algunas variantes, la estructura externa del sistema finalista, básicamente, considerando el "dolo" como parte del tipo. ${ }^{186}$

Lo que a Politoff interesaba en ese momento no era la "elaboración" de un sistema de la teoría del delito más o menos original, sino ofrecer un texto general que recogiese lo que consideraba debiera ser un "Derecho penal con mesura", según lo denominase en un artículo del año 1996, escrito con ocasión de su incorporación como Profesor Titular a la Universidad de Talca. Es aquí donde explicita, en plena madurez intelectual, los fundamentos de su forma de entender el Derecho penal, su legitimación y su función en la sociedad: su rechazo a la pretensión de que el Derecho penal tenga como finalidad mantener la fidelidad u otra clase de sentimiento hacia el ordenamiento de los ciudadanos, limitándolo a la protección coactiva de intereses individuales y colectivos, los bienes jurídicos en el sentido de v. Liszt, en un marco del respeto a los principios de legalidad, ultima ratio, proporcionalidad; y por lo mismo, su acuerdo con la reducción del ámbito de lo punible, pero sólo en la medida que existan realmente otras vías eficaces para la protección de esos intereses, menos lesivas para la libertad individual

\footnotetext{
${ }^{184}$ Supra, nota al pie $\mathrm{n}^{\mathrm{o}} 105$ y el texto a que hace referencia.

${ }^{185}$ POLITOFF L., Sergio, Derecho Penal, Tomo I, $2^{a}$ ed., Santiago: Conosur, 2000, p. 65s. Por lo tanto, la adopción del sistema "neoclásico" no parece derivarse en Politoff simplemente de la reafirmación de una postura que adoptase treinta años antes o de una supuesta "desactualización" de sus conocimientos, lo que desmiente la profusa y actualizada (al momento de la publicación del texto) bibliografía, así como los contenidos tratados, que incluyen la hasta entonces no considerada en extenso en las obras generales impresas en Chile, "teoría de la imputación objetiva".

${ }^{186}$ Como sucedía en la edición del Derecho penal de Roxin, que tuvo a la vista Politoff al momento de escribir su texto, como aparece de las respectivas notas al pie y me consta personalmente (ROXIN, Claus, Strafrecht. AllgemeinerTeil. Band I, Grundlagen. Der Aufbau der Verbrechenslehre, 2. Aufl., München: Verlag C.H. Beck, 1994, pp. 184-188, y 195 y 247-250). Una exposición de la teoría de la acción de Roxin puede verse en el último trabajo publicado en Chile de Álvaro BUNSTER, "Acerca de la concepción roxiniana de la acción jurídico penal”, Revista de Estudios de la Justicia, No 3 (2003), pp. 1120 .
} 
MATUS, Jean Pierre "Origen, consolidación y vigencia de la

Nueva Dogmática Chilena (ca. 1955 1970)"

que el propio Derecho penal y, además, que la descriminalización no sea un mero reflejo del desinterés de los poderosos por la protección de ciertos bienes jurídicos. ${ }^{187}$

\section{Epílogo: Alejamiento y exilio. Decadencia del Instituto de Ciencias Penales y de la Revista de Ciencias Penales. Pérdidas personales y vigencia de la Nueva Dogmática Chilena}

\subsection{Alejamiento y exilio}

Como hemos visto hasta ahora, el año 1956 marcó profundamente a quienes serían parte de la Nueva Dogmática Chilena: por un lado, muchos de ellos asistieron al "Curso Profundizado" sobre "Culpabilidad" que ofreció Álvaro Bunster en la Universidad de Chile, mientras otros desarrollaban con él sus Memorias de Grado o asistían a sus cursos regulares de pregrado; por otro, la Ley No 12.265 otorgó al Instituto de Ciencias Penales autonomía financiaría que le permitió adquirir el local y financiar la Revista de Ciencias Penales a través de la cual esta nueva generación se expresaría, gracias a la administración del Instituto durante los diez años que lo presidiera Eduardo Novoa Monreal. El año 1970 marcaría, a su vez, el alejamiento personal y el inicio del fin de la amistad cívica entre "maestros" y "discípulos", y también entre ellos mismos: Álvaro Bunster sería nombrado Embajador en Inglaterra, Eduardo Novoa asumió labores de asesoría ad honorem del Gobierno de Allende, que le llevaron a ser nombrado Embajador especial en Francia para la Defensa de la Nacionalización del Cobre; Sergio Politoff se integraría a la asesoría jurídica del Ministerio del Interior; mientras Juan Bustos sumaba a sus labores académicas las del Partido Socialista, como Secretario Regional Centro.

Tras el Golpe de Estado del 11 de septiembre de 1973, todos ellos partieron a la trashumancia y diáspora del exilio, terminando Bunster en México, Novoa en Venezuela, Bustos en España, y Politoff en Holanda. Los miembros de la Nueva Dogmática Chilena que se quedaron en el país se encontraban divididos entre quienes asumieron defensas de los perseguidos ante los Tribunales de Guerra instalados por la Dictadura Militar y quienes aprobaban, callada o públicamente, al nuevo gobierno, prestándole incluso "asesoría legislativa". ${ }^{188}$

Este fue, antes que el natural reemplazo generacional tuviese lugar, el fin traumático que, como generación, padeció la Nueva Dogmática Chilena.

\subsection{Decadencia del Instituto de Ciencias Penales y de la Revista de Ciencias Penales}

Mientras los exiliados de cierto modo pudieron vivir una "nueva juventud", y refrescar sus conocimientos y perspectivas, al tomar contacto con las ideas y profesores europeos

\footnotetext{
${ }^{187}$ POLITOFF, Sergio, "Derecho penal con mesura: una respuesta reduccionista a la mala conciencia del jurista”, Revista Universum (Universidad de Talca), Año 10 (1995), pp. 95-106.

${ }^{188}$ Diferencias políticas que se veían claramente entre miembros de las antiguas generaciones tras el Golpe de Estado, como se ve en la nota al pie $n^{\circ}$ 100, p. 51 del Derecho Penal de COUSIÑO Mac Iver (cit. nota al pie $\mathrm{n}^{\mathrm{o}} 31$ ), donde, "a propósito" de la idea de la vinculación del Derecho penal con la "naturaleza de las cosas", acusa a Novoa de permanente "claudicación" con sus "principios" por apoyar al Gobierno de la Unidad Popular y asesorarlo legislativamente. Estas diferencias permanecerían más allá del término de la Dictadura, como demuestra el aislamiento de Novoa a su regreso a Chile y el sutil rechazo que GRISOLÍA deja traslucir respecto de la persona de Politoff en una "Recensión" que hiciera sobre su Derecho Penal (Revista del Abogado, No 11 (1997), p. 43).
} 
Polit. crim. Vol. 6, № 11 (Julio 2011), Art. 3, pp. 44 - 105.

[http://www.politicacriminal.cl/Vol_06/n_11/Vol6N11A3.pdf]

en los países que los recibieron; quienes quedaron en Chile, en cambio, padecieron el aislamiento y la paralización que las divisiones políticas subyacentes fue imponiendo a las actividades comunes.

La paulatina decadencia del Instituto de Ciencias Penales y de su Revista de Ciencias Penales, grafican mejor que nada el efecto paralizante de la división política en esta generación.

En cuanto al Instituto, el año 1970 Miguel Schweitzer S., a la sazón de 62 años, asumió la presidencia al retirarse Eduardo Novoa, manteniéndose como Secretario Ejecutivo Francisco Grisolía. ${ }^{189}$ Ambos permanecieron en sus cargos tras el Golpe de Estado de 1973. Sin embargo, Eduardo Novoa, Sergio Politoff y Juan Bustos, Directores en los años 1970-1973, son apartados de sus cargos tras el cambio de Gobierno. En cambio, Miguel Schweitzer S. permaneció en el cargo de Presidente del Instituto hasta la década de 1980 (así figura en el Tomo XXXVII (1978-1981) de la Revista de Ciencias Penales). En este período fue también Ministro de Justicia de la Dictadura Militar (1975-1977). Ello le permitió organizar en Santiago, el año 1976, una reunión plenaria del Código Penal Tipo para Latinoamérica (cuyo Presidente de Honor fue nada menos que el General Pinochet). ${ }^{190}$ Sin embargo, se trataba ya de un esfuerzo sin sentido, encontrándose varios de los más destacados penalistas chilenos en el exilio, incluyendo al creador e impulsor del proyecto (Eduardo Novoa Monreal). ${ }^{191}$

Desde 1976 hasta 1989 las reuniones científicas e invitaciones de profesores extranjeros, salvo alguna esporádica excepción, pasaron a ser un recuerdo de años perdidos. ${ }^{192}$ Producido el regreso a la democracia, el Instituto tuvo en los años 1990 un nuevo Presidente, Sergio Yáñez Pérez, quien ya tenía 65 años, y Secretario Ejecutivo (Juan Cárcamo Olmos). Vicepresidente fue Alfredo Etcheberry y Secretario, Enrique Cury. La Nueva Dogmática Chilena se hacía cargo otra vez, pero ello no fue suficiente para reimpulsar las actividades del Instituto, que se mantuvieron el letargo de la época de la Dictadura Militar. Sergio Yáñez murió en el cargo (2006) y ha sido sucedido por Alfredo Etcheberry, manteniendo la Secretaría Ejecutiva Juan Carlos Cárcamo hasta hoy en día. El año 2000 entró en vigencia el Código Procesal Penal que privó al Instituto de los fondos que le otorgaba la Ley $\mathrm{N}^{\mathrm{o}} 12.265$ de 1956. Hoy ya no funciona en su local propio y su biblioteca opera anexa a de la del Centro de Estudios de Derecho Penal del Campus Santiago de la Universidad de Talca.

Por su parte la Revista de Ciencias Penales perdió su regularidad y la vitalidad de la década de 1960, publicándose apenas siete tomos entre 1974 y 1989, muchos de ellos

\footnotetext{
${ }^{189}$ INSTITUTO DE CIENCIAS PENALES, "Memoria de las actividades desarrolladas entre los meses de abril de 1970 y marzo de 1971 por el Instituto de Ciencias Penales", Revista de Ciencias Penales, T. XXX (1971), pp. 107-110, p. 107.

${ }^{190}$ Los documentos respectivos se encuentran en el Archivo del Instituto de Ciencias Penales, actualmente depositados en el Centro de Estudios de Derecho Penal de la Universidad de Talca (Campus Santiago).

${ }^{191}$ La crítica política a la continuación de estos trabajos en una época en que en América Latina proliferaban las dictaduras, puede verse en RIVACOBA Y RIVACOBA, Manuel de, "Pensamiento penal y criminológico del Código penal tipo para Iberoamérica", Doctrina Penal, Año 10, Nº 37 a 40 (1987), pp. 713-734.

${ }^{192}$ Sólo en las postrimerías de la década de 1980 la Revista de Ciencias Penales publica las ponencias que J. Cerezo M., W. Schöne y Sch. Springorum dictaron invitados por el Instituto y que sirvieron para alimentar su T. XXIX (1987-1989).
} 
compuestos de un solo número y con escasos artículos de doctrina. ${ }^{193}$ Después, sólo en 1994 aparecería el que hasta hoy es su último tomo (XL, 1990-1994), publicado gracias al esfuerzo personal de Juan Bustos, quien asumió su Dirección al regreso de su exilio. $^{194}$

\subsection{Pérdidas personales y vigencia de la Nueva Dogmática Chilena}

Con el paso de los años, llegó el envejecimiento y la muerte. Ya no se encuentran entre nosotros Juan Bustos, Sergio Politoff, Sergio Yáñez y Francisco Grisolía.

Y tampoco está presente la discusión entre el "sistema neoclásico" y el "sistema finalista". ${ }^{195}$ Del mismo modo, con la caída del Muro de Berlín pasó el tiempo de la "crítica" (marxista) del Derecho y de la "criminología crítica" como fundamento para la limitación del Derecho penal. ${ }^{196}$

Ahora se discute entre categorías y sistemas globales: Strafrechtswissenschaft vs. Common Law; ${ }^{197} \mathrm{y}$, dentro de la dogmática alemana, entre variaciones del denominado funcionalismo, básicamente, entre el modelo de Roxin y el de Jakobs. ${ }^{198} \mathrm{Si}$ algo queda vigente de la "antigua" disputa sería, como sostiene Jakobs respecto de Welzel, el "esquema", "no el sistema", esto es, no "sus fundamentos" ("la teoría final de la acción" como "superación" de la "teoría causal"). ${ }^{199}$ Y lo mismo valdría para un sistema "crítico" como el de Bustos.

¿Significa esto que todo o buena parte del material producido por la Nueva Dogmática Chilena se encuentra en rápido proceso de considerarse "obsoleto" y perder su vigencia cuando ya no quede nadie de sus miembros con vida para sostener sus ideas en la cátedra universitaria y la discusión científica?

Al respecto, habría que distinguir dos etapas: la de los años 1960, centrada en la discusión entre el "sistema neoclásico" y el "sistema finalista"; y la de los últimos 20

\footnotetext{
${ }^{193}$ El análisis detallado de este período de la Revista y de la ciencia penal chilena corresponde, no obstante, a otra etapa de la investigación en que se enmarca este artículo.

${ }^{194}$ En este último Tomo se pretendía retomar una regularidad cuatrimestral, publicándose tres números. La numeración que ellos traen es, con todo, confusa (en el № 1 el Tomo es XL, y en el No 3 , XLII). Sin embargo, Juan Bustos haría posteriormente de la política su actividad principal (ver nota al pie $\mathrm{N}^{\mathrm{o}} 172$ ) y hasta la fecha, nada se ha hecho para revitalizar la Revista.

${ }^{195}$ En su última monografía publicada en Chile, Bustos señalaba -con la perspectiva que da el tiempoque "el finalismo no es totalmente contradictorio con el causalismo ni tampoco su superación ... El finalismo es en sí la culminación de la dogmática tradicional o clásica, que parte de estructuras categoriales u ontológicas y desde esa perspectiva se ve en la necesidad de reconocer a la causalidad como tal una estructura, de ahí que aunque parezca paradojal el finalismo es también o además de un causalismo naturalista puro" (BUSTOS, Juan, El Delito Culposo, Santiago: Ed. Jurídica de Chile, 1995, p. 9, nota al pie $\mathrm{n}^{\mathrm{o}} 2$ ).

${ }^{196}$ Al respecto, véase LARRAURI, Elena, La herencia de la criminología crítica, Madrid: Siglo XXI Ed., 1991, especialmente pp. 191-243.

${ }^{197}$ Véase MATUS, La transformación, cit. nota al pie $\mathrm{n}^{\circ}$ 43. Una recesión crítica del texto aparece en MELENDO PARDOS, Mariano, “¿Strafrechtswissenschaft o Common Law? A propósito de Matus Acuña, Jean Pierre: La transformación de la teoría del delito en el derecho penal internacional,", Revista

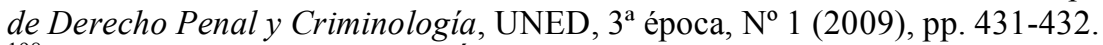

${ }^{198}$ Véase al respecto, SILVA SÁNCHEZ, Jesús María, Aproximación al Derecho penal contemporáneo, Barcelona: Bosch, 1992, pp. 68-72.

${ }^{199}$ JAKOBS, Günther, "Schriftum: Oliver Sticht, 'Sachlogikals Naturrecht? Zur Rechtsphilosophie Hans Welzels (1904-1977)'”, Goltdammer's Archiv für Strafrecht 148 (2001), pp. 492-494, p. 493.
} 
Polit. crim. Vol. 6, № 11 (Julio 2011), Art. 3, pp. 44 - 105.

[http://www.politicacriminal.cl/Vol_06/n_11/Vol6N11A3.pdf]

años (1990-2010). Seguramente esta primera etapa ya puede considerarse "histórica" o en vías acelerada de serlo.

En cambio, dado que todavía ejercen la abogacía y la docencia universitaria algunos de los miembros más destacados de la Nueva Dogmática Chilena, sus partes generales (o sus continuaciones) se siguen publicando y enseñando en las Universidades chilenas y, sobre todo, que no se ha publicado aún entre nosotros un texto que permita reemplazarlas en la enseñanza universitaria y en el trabajo forense, es de presumir que no sólo el "esquema", sino también el "contenido" de ellos permanecerán por un tiempo más como referencia para la enseñanza, discusión y solución de los problemas del Derecho penal chileno de hoy. ${ }^{200}$

No obstante, si se tienen en cuenta las condiciones que dieron origen a la Nueva Dogmática Chilena, es posible suponer que, con independencia del valor del "contenido" de sus aportes, probablemente veamos en el mediano plazo el surgimiento de otra generación, que la reemplace. En efecto, en primer lugar, la sola constatación de la existencia de nuevos derroteros sistemáticos en Alemania hace presumir que éstos se trasladarán hacia nosotros en algún momento. ${ }^{201}$ En segundo término, se puede constatar que esta última década ha resurgido el interés por los estudios de postgrado en el extranjero y, especialmente, en Alemania, existiendo ya en Chile discípulos directos de Roxin y Jakobs, en plena actividad universitaria. ${ }^{202}$ En tercer lugar, las reformas al sistema universitario de las últimas décadas han permitido la creación de numerosos centros universitarios y plazas para que estos estudiantes de doctorado, una vez titulados, puedan desarrollar su vocación académica. ${ }^{203}$ En cuarto lugar, la competencia entre las instituciones universitarias les ha obligado a volver a invertir en la dotación bibliográfica de sus bibliotecas, para preparar los cursos de Magíster y Doctorado que dictan y a convenir intercambios para que sus estudiantes visiten instituciones extranjeras y puedan tener contacto con la bibliografía actualizada. ${ }^{204}$ En quinto término, la existencia de Fondos Concursables para Ciencia y Tecnología

\footnotetext{
${ }^{200}$ La cuestión, con todo, es algo más difícil tratándose del sistema de Bustos, dado que su Manual y las continuaciones (ver nota al pie $\mathrm{N}^{\circ} 176$ ) se refieren al Derecho español.

${ }^{201} \mathrm{Al}$ respecto, véase MATUS, "Por que citamos a los alemanes", cit. nota al pie $\mathrm{n}^{\circ} 122$. Esta relación de dependencia, traducida en "una cierta acomodación de nuestro derecho a la estructura orgánica y evolucionada presentada por los tratadistas alemanes", vacía de un sustrato de elaboración propia en cuanto al "contenido" de las mismas, esto es, respecto de "las instituciones" subyacentes, ya había sido anticipada por uno de los miembros de la Nueva Dogmática Chilena, Enrique Cury, quien, no obstante, como ya hemos visto, al elaborar sus propios textos generales años más tarde, no se alejaría demasiado de lo que en 1964 denunciaba (CURY, Enrique, "Sobre la evolución del Derecho penal chileno", Revista de Ciencias Penales, T. XXIII (1964), pp. 154-160, p. 156).

${ }^{202} \mathrm{Y}$ uno de ellos ya ha dado señales de que publicará en algún momento más o menos próximo el libro de texto de su inclinación sistemática, en su caso, el funcionalismo de Jakobs, que sirva a la enseñanza universitaria (PIÑA, Juan Ignacio, Derecho penal, fundamentos de la responsabilidad, Santiago: Abeledo Perrot, 2010).

${ }^{203}$ Por ejemplo, en 20010 se concursaron 9 plazas en la Universidad de Chile, 2 de ellas de jornada completa. Hay también plazas de Jornada completa en las Universidades Católica de Valparaíso, de Valparaíso, Austral de Chile (Valdivia), y de Talca. Incluso Universidades privadas, como la Diego Portales, Alberto Hurtado y Adolfo Ibáñez cuentan con profesores de Jornada Completa en Derecho penal. La gran mayoría de estos profesores ha realizado estudios de Doctorado en Alemania o España.

${ }^{204}$ Un ejemplo de la renovación en la dotación bibliográfica es el caso del Centro de Estudios de Derecho Penal del Campus Santiago de la Universidad de Talca, que estuvo bajo la dirección de J.P. MATUS entre 2004 y 2010, en donde actualmente se encuentra la más dotada y actualizada colección en la materia del país, junto con la del Instituto de Ciencias Penales, recuperada para el uso público tras el cierre de su antiguo local.
} 


\section{MATUS, Jean Pierre "Origen, consolidación y vigencia de la Nueva Dogmática Chilena (ca. 1955 1970)"}

(FONDECYT) ha incentivado la publicación en Revistas científicas y ya existe una nueva revista especializada en Derecho penal, que ha mantenido su regularidad en este último lustro. ${ }^{205} \mathrm{Y}$, finalmente, la aparición de nuevos textos generales (con un fundamento y sistema diferente a los actuales en uso) se hará imprescindible por la necesaria adecuación de los textos actuales al Nuevo Sistema Procesal Penal, introducido en Chile el año 2000 y a los numerosos cambios legislativos producidos en esta época expansiva de la política criminal en las sociedades actuales, tanto por presiones internas como producto de la suscripción de numerosos tratados internacionales en la materia. ${ }^{206}$

\footnotetext{
${ }^{205}$ Sobre la nueva "explosión" de publicaciones en materia penal y las revistas que las contienen, a partir de la década de 1990, véase lo expuesto en MATUS / CARNEVALI, "Análisis...", cit. nota al pie nº 11, pp. 25 a 29. La Revista especializada a que se hace referencia es Politica Criminal, Revista Electrónica Semestral editada por el Centro de Estudios de Derecho Penal de la Universidad de Talca [http://www.politicacriminal.cl], de la cual fue su Director desde el $N^{\circ} 1$ (2006) hasta el No 8 (2009) J.P. MATUS. Actualmente la dirige el Dr. Raúl CARNEVALI y está indexada en SCIELO. También tiende a la especialización en materias penales y a la indexación la Revista de Estudios de la Justicia, del Centro homónimo de la Universidad de Chile, dirigido por la Dra. María Inés Horvitz L. Y se debe contar, además, con la recientemente aparecida Doctrina y jurisprudencia penal, dirigida por la Dra. Tatiana Vargas y publicada por la Universidad de Los Andes a través de la editorial Abeledo Perrot.

${ }^{206}$ Véase Silva Sánchez, Jesús María, La expansión del Derecho penal, Aspectos de la política criminal en las sociedades postindustriales, $2^{a}$ ed., Madrid, 2001; y MATUS, Jean Pierre, "La política criminal de los tratados internacionales", en CARNEVALI, Raúl (Coord.), Cuestiones de política criminal en los tiempos actuales, Santiago: Ed. Jurídica, 2009, pp. 105-134.
} 
Polít. crim. Vol. 6, No 11 (Julio 2011), Art. 3, pp. 44 - 105.

[http://www.politicacriminal.cl/Vol_06/n_11/Vol6N11A3.pdf]

\section{BIBLIOGRAFÍA CITADA}

ABANTO, Manuel, "Acerca de la teoría de los bienes jurídicos", en Urquizo, José (Dir.), Modernas tendencias de dogmática penal y política criminal. Libro homenaje al Dr. Juan Bustos Ramírez, Lima: Idemsa, 2007, pp. 1-78.

ABARZA, René, Pedro Pablo Ortiz Muñoz: vida obra e influencia en el derecho penal chileno, Tesis UTal, Talca: 2005 (Prof. Guía: JP Matus).

AFTALIÓN, Enrique, "El bien jurídico tutelado por el Derecho penal económico", Revista de Ciencias Penales, T. XXV (1966), pp. 79-91.

AGÜERO, Felipe, La reforma en la Universidad de Chile, T. III, Santiago: Eds. Sur, 1987,

ALCALÁ ZAMORA, Niceto, “¿Constituyen "injurias causadas en juicio” las proferidas en un procedimiento de jurisdicción voluntaria?", Revista de Ciencias Penales T. XXII (1963), pp. 27-39.

ALESSANDRI R., Arturo, "Revista de Ciencias Penales", Revista de Ciencias Penales, T. I (1935), No 1, p. 3.

AMBOS, Kai, "100 años de la $<<$ teoría del delito $>>$ de Beling ¿renacimiento del concepto causal del delito en el ámbito internacional?", Revista Electrónica de Ciencias Penales y Criminología, 09-05 (2007), pp. 05:01-05:15, en http://criminet.ugr.es/recpc/09/reccpc09-05.pdf

BAEZA M., Mario, Esquema y notas para una historia de la Facultad de Ciencias Jurídicas y Sociales de la Universidad de Chile, Santiago: Tesis UCh, 1944, p. 222.

BALliviAN H., José, El delito de apropiación indebida (art. $470 N^{o} 1$ del Código penal), Tesis UCh, Santiago: La Gratitud, 1937.

BASCUÑÁN V., Antonio, El delito de abusos deshonestos, Tesis Uch, Santiago: Ed. Jurídica de Chile, 1961,

-El delito de incendio (Coord.), Santiago: Ed. Jurídica, 1974.

BELING, Ernst v., Esquema del Derecho penal / La doctrina del delito-tipo, Trad. de las ediciones alemanas de 1930 por S. Soler, Buenos Aires: Depalma, 1944.

BELMAR, Roberto; GANDULFO, Pedro; GUERRERO, Juan, Derecho penal, apuntes tomados en clase de don Ricardo Cabieses, ampliados y redactados, Santiago: Imp. Estrella del Pacífico, 1918.

BERGALLI, Roberto, "Una ética absoluta y vital. Eduardo Novoa Monreal (19162006)", en VILLEGAS (Coord.), Contribuciones, pp. 11-18.

BERISTAIN, Antonio, "La reforma del Código penal Alemán", Revista de Ciencias Penales T. XXVIII (1969), pp. 46-63.

BERNALES, Emmanuel, Álvaro Bunster Briceño: vida, obra e influencia en el Derecho penal actual, Tesis UTal, Talca: 2009 (Dir. J.P. MATUS).

BRANDAU, Valentín, "Introducción al estudio del Derecho penal", Revista de Ciencias Penales, T.I (1935), pp. 122-135, 302-317, 498-503, p. 500.

BULLEMORE, Vivian, "En memoria de Francisco Grisoli a Corbato n", La Semana Jurídica, No 239 (2005), p. 15.

BUNSTER, Álvaro, La malversación de caudales públicos. Estudio de doctrina y jurisprudencia, Tesis UCh, Santiago: 1948.

— "La voluntad del acto delictivo", Revista de Ciencias Penales, T. XII (1950), pp. 148-178.

— "Finalidad de las penas privativas de libertad", Revista de Ciencias Penales, T.XIV (1954), pp. 67-74.

- "Acerca de la concepción roxiniana de la acción jurídico penal", Revista de 
MATUS, Jean Pierre "Origen, consolidación y vigencia de la

Nueva Dogmática Chilena (ca. 1955 1970)"

Estudios de la Justicia, № 3 (2003), pp. 11-20.

BUSTOS R., Juan, La valoración objetiva y subjetiva en la teoría de la acción, Tesis Inédita, Madrid: Univ. Complutense, ca. 1960.

- Concurso ideal de delitos, Tesis UCh,Santiago: Ed. Universitaria, 1962.

-Finalität, fahrlässiges, Begehungsdelikt und chilenisches Strafgesetzbuch, UniBonn: Diss., 1965.

- Culpa y finalidad. Los delitos culposos y la teoría final de la acción, Santiago: Ed. Jurídica de Chile, 1967).

-Control Social y Sistema Penal, Barcelona: PPU, 1987.

— "Consideraciones en torno al injusto" (1974), en del mismo, Control Social y Sistema Penal, pp. 141-157.

- "Política criminal e injusto (Política criminal, bien jurídico, desvalor de acto y de resultado)" (1978), en del mismo, Control Social, pp. 159-180.

— "Criminología crítica y Derecho penal" (1987), en del mismo, Control Social y Sistema Penal, pp.15-29.

-Manual de Derecho penal. Parte general, $3^{a}$ ed., Barcelona: Ariel 1989.

-El Delito Culposo, Santiago: Ed. Jurídica de Chile, 1995.

-Obras Completas, Tomo I, Lima: Ara Eds., 2004.

BUSTOS R., Juan; HORMAZÁBAL, Hernán, Lecciones de Derecho Penal, Madrid: Trotta, 2006.

BUSTOS R., Juan; SOTO, Eduardo, "Voluntaria significa culpabilidad en sentido restringido", Revista de Ciencias Penales, T. XXIII (1964), pp. 243-264.

CABELLO, Carlos, Rafael Fontecilla Riquelme: Vida, obra e influencia en el Derecho Penal Chileno, Tesis UTal, Talca: 2005 (Prof. Guía: JP MATUS).

CABRERA B., Gonzalo, Del concepto jurídico de delito, Tesis UCh, Santiago: Leblanc, 1941.

CARDENAL M., Sergi, El tipo penal en Beling y los neokantianos, U. De Barcelona: Tesis Doctoral, 2002, pp. 29-82, disponible en internet en [http://www.tdr.cesca.es/TESIS_UB/AVAILABLE/TDX-0604102083801/TOL77.pdf].

CARNEVALI, Raúl, Cuestiones de politica criminal en los tiempos actuales (Coord.), Santiago: Ed. Jurídica, 2009.

- "La ciencia penal italiana y su influencia en Chile", Política Criminal, No 6 (2008), A4-6, pp. 1-19, en [http://www.politicacriminal.cl/n 06/a 4 6.pdf].

COBO, Manuel, "Función y naturaleza del artículo 226 del Código penal español", Revista de Ciencias Penales, T. XXVI (1967), pp. 127-150.

CORNEJO L., Hernán, La responsabilidad cuasidelictual del médico, Santiago: Talleres Gráficos Valdés Hermanos, Tesis UCh, 1945.

COUSIÑO Mac Iver, Luis, De la condición suspensiva, Tesis UCh, Santiago: Imp. Santiago, 1926.

-Herencia biológica y Derecho: Individualidad Biológica y en Especial Individualidad Sanguínea, Santiago: Editorial Nascimento, 1941.

- Breve Curso de Medicina Legal (para el uso de los alumnos del quinto año de las escuelas de derecho), Santiago: Politécnico de Menores Alcibíades Vicencio, 1941.

- Manual de Medicina Legal, Santiago: Editorial Jurídica de Chile, 1948.

— "La interpretación bio-psicológica del delito", Revista de Ciencias Penales, T. VII (1944), pp. 301-314.

— "La falsificación de instrumento privado", Revista de Ciencias Penales, T. VII (1944), pp. 5-23 y 99-131. 
Polit. crim. Vol. 6, № 11 (Julio 2011), Art. 3, pp. 44 - 105.

[http://www.politicacriminal.cl/Vol_06/n_11/Vol6N11A3.pdf]

— “Pedro Ortiz Muñoz”, Revista de Ciencias Penales, T. IX (1946), № 2, pp. iiiiv.

- "Los delitos contemplados en la Ley de Cheques", Revista de Ciencias Penales, T. X (1948), pp. 97-105.

- Cousiño Mac Iver, Luis, "La interpretación de la ley penal en la dogmática chilena", Revista de Ciencias Penales, Tomo XIX (1960), pp. 197-218.

— "El delito socioeconómico", Revista de Ciencias Penales, T. XXI (1962), pp. 47-63,

— "El dolo eventual en la dogmática chilena", Revista de Ciencias Penales, T. XXVII (1968), pp. 225-132.

- "Influencia de Jiménez de Asúa en los penalistas chilenos", Revista de Ciencias Penales, T. XXX, No 1 (1971), pp. 5-8.

- "Los integrantes subjetivos de la justificación", Revista de Ciencias Penales, T. XXXIII (1974), pp. 26-33.

- Derecho penal chileno, Tomo I, Santiago: Ed. Jurídica de Chile, 1975.

CRIADO, Martín, "Generaciones / Clases de Edad", en Reyes, Román (Dir.), Diccionario crítico de Ciencias Sociales, U. Complutense de Madrid, [http://www.ucm.es/info/eurotheo/diccionario/G/generaciones.htm].

CURY U., Enrique, "Interpretación del artículo 343 del Código penal", Revista de Ciencias Penales, T. XVII (1958), No 3, pp. 86-91.

— "La ausencia de tipicidad en el Código penal", Revista de Ciencias Penales, T. XIX (1960), pp. 51-57.

- El delito continuado, Tesis UCh, Santiago: Ed. Jurídica, 1962 [=Revista de Ciencias Penales, T. XVIII (1959), pp. 104-123 (primera parte) y pp. 201-215 (segunda parte), p. 204].

- "La teoría del principio de ejecución en la tentativa", Revista de Ciencias Penales, T. XXII (1963), pp. 167-195.

- "Sobre la evolución del Derecho penal chileno", Revista de Ciencias Penales,

T. XXIII (1964), pp. 154-160.

- Orientación para el estudio de la Teoría del Delito, Valparaíso: Edeval, 1969, pp. 214-220.

- "Contribución al estudio de la responsabilidad médica por hechos culposos",

Revista de Ciencias Penales, T. XXXVII (1978-1981), pp. 97-10.

- "El concepto de autor mediato como categoría imprescindible en la interpretación de la ley penal chilena" (Revista Chilena de Derecho, Vol. XII (1985), pp. 35-53.

- Derecho penal, parte general, Santiago: Ed. U. Católica de Chile, 2005.

DOHNA, Alexander Graf zu, La estructura de la teoría del delito, Trad. C. Fontán B., Buenos Aires: Abeledo-Perrot, 1958.

DRAPKIN, Abraham, "La menor edad”, Revista de Ciencias Penales, T. III (1937), pp. 53-29.

— "Defensa Legítima", Revista de Ciencias Penales, T. IV (1938), pp. 36-56.

- "Uxoricidio por adulterio", Revista de Ciencias Penales, T. IV (1938), pp. 406-415.

- "Apuntes para la formación del vocabulario del hampa chilena", Revista de Ciencias Penales, T.IV (1938), p. 484-492.

- Relación de causalidad y delito. Santiago: Cruz del Sur, 1943.

ESER, Albin, "Justification and Excuse: A Key Issue in the Concept of Crime", en Eser, A.; Fletcher, G., Rechtfertigung und Entschuldigung. Bd. I, Freiburg i. Bgr.: Max-Planck Institut für ausländisches und internationals Strafrecht, 1987, p. 62. 
MATUS, Jean Pierre "Origen, consolidación y vigencia de la

Nueva Dogmática Chilena (ca. 1955 1970)"

ESPINOZA H., Mauricio, Gustavo Labatut Glena: vida, obra y aporte al Derecho penal actual, Tesis UTal, Talca: 2005 (Prof. Guía: JP MATUS).

ETCHEBERRY O., Alfredo, El concurso aparente de leyes penales, Tesis UCh, Santiago: Ed. Jurídica, ca. 1955.

- "Reflexiones críticas sobre la Relación de Causalidad", Revista de Ciencias Penales, T. XVIII (1959), pp. 175-200.

— "El objeto jurídico en los delitos de falsedad documental", Revista de Ciencias Penales, Tomo XX (1960), pp. 33-66.

- "El objeto material de la falsedad documental: Documentos y sus clases", Revista de Ciencias Penales, Tomo XX (1960), pp. 219-240.

- Derecho penal, parte general, T. I, Santiago: Gibbs Eds., 1964.

- Derecho penal, parte general, T. I, $3^{a}$ ed., Santiago: Ed. Jurídica, 1997.

- "La Corte penal internacional - Jurisdicción, estructura, funcionamiento", Revista de Derecho [U. Católica Concepción], No 10 (2002), pp. 551-568.

— "El foro penal y el sistema de penas" (Revista de Derecho [Coquimbo], № 9 (2002), pp. 7-25.

— "Reflexiones sobre Política Criminal", Política Criminal, Vol. 4, No 7 (2009), D2, pp. 235-249 [ http://www.politicacriminal.cl/n_07/d_2 7.pdf].

FERNÁNDEZ, Álvaro, "Miguel Schweitzer Speisky: penalista", en SCHWEITZER W. (Coord.), Nullum crimen, pp. 109-124.

FONTECILLA R., Rafael, "El concepto jurídico de delito y sus principales problemas técnicos", Revista de Ciencias Penales, T.II (1936), p. 21-51, pp. 31-33 y 45.

- "Luis Jiménez de Asúa y sus múltiples facetas", Revista de Ciencias Penales, T. XXX, No 1 (1971), pp. 12-22.

— "Geheimer Rat Dr. Ernst von Beling (Dem Rektorat der Universität München als Beileidsbezeugung)", Anales de la Universidad de Chile (1933), primer trimestre, pp. 41-52.

- Derecho Procesal Penal, Santiago: Imp. E1 Imparcial, 1943.

- Derecho Procesal Penal, $2^{a}$ ed., Santiago: Ed. Jurídica de Chile, 1978.

- Concursos de delincuentes, de delitos y de leyes penales y sus principales problemas jurídicos. Santiago: Editorial Jurídica de Chile, 1956.

— "Das chilenische Strafrecht", en Mezger; Schönke (†); Jescheck (Eds.), Das ausländische Strafrecht der Gegenwart, Berlín: Duncker \& Humblot, 1959, pp. 9132.

— "Luis Jiménez de Asúa y sus múltiples facetas", Revista de Ciencias Penales, T.XXX, (1971), pp. 12-22.

FRAGOSO, Heleno Claudio, "Notas sobre el concepto de delito en el Derecho soviético", Revista de Ciencias Penales T. XXII (1963), pp. 297-303.

FUENTES Z., Myrtha, Cuasidelito penal, Tesis UCh, Santiago: Imp. Fuentealba, 1946.

GALLAS, Wilhelm, La teoría del delito en su momento actual, Trad. J. Córdoba R., Barcelona: Bosch, 1959.

GISBERT, Juan Antonio, "El trastorno mental transitorio según la legislación y la jurisprudencia españolas", Revista de Ciencias Penales, T. XXV (1966), pp. 3-25.

GRISOLÍA, Francisco, El objeto jurídico del delito. (Prolegómenos para el estudio de la objetividad jurídica en los delitos de Falsedad documental), Santiago: s/e, 1959 [="El objeto jurídico del delito", Revista de Ciencias Penales, T. XVII (1958), No 3, pp. 3-85].

- El Código penal tipo para Hispanoamérica: proceso formativo y estudio crítico trabajo, Tesis UCM, Madrid: U. Complutense, 1967.

- "Jiménez de Asúa y las nuevas generaciones de penalistas", en Revista de 
Polit. crim. Vol. 6, № 11 (Julio 2011), Art. 3, pp. 44 - 105.

[http://www.politicacriminal.cl/Vol_06/n_11/Vol6N11A3.pdf]

Ciencias Penales, T.XXX (1971), pp. 9-11, p. 10.

- "La estafa procesal", Revista Chilena de Derecho, Vol. 24, No 3 (1997), pp. 417-422.

— "El delito de asociación ilícita", Revista Chilena de Derecho, Vol. 31, No 1 (2004), pp. 75-88.

— "Recensión", Revista del Abogado, № 11 (1997), p. 43).

GRISOLÍA, Francisco; NÁQUIRA, Jaime; VIVANCO, Jaime, "La remisión condicional de la pena y la libertad condicional en el sistema chileno de ejecución de sanciones", Revista de Ciencias Penales, T. XXXII (1973), pp. 93-110.

GUERRA G., Beatriz, Eduardo Novoa Monreal: Vida, obra e influencia dogmática en el derecho penal actual, Tesis UTal, Talca: 2005 (Dir. J.P. MATUS).

GUZMÁN DALBORA, José Luis, El penalista liberal. Controversias nacionales e internacionales en Derecho penal, procesal penal y Criminología (Coord.), Buenos Aires: Hammurabi, 2004.

—_Un ejemplo de coherencia", en: del mismo (Coord.), El penalista liberal, pp.47-54.

- "Estudio Necrológico: Sergio Politoff Lifschitz o la Perseverancia Creadora de una Vida Inmigrante," Política Criminal, Vol. 5, No 9, (Julio 2010), Doc. 1, pp. 257-276, en [http://www.politicacriminal.cl/Vol_05/n_09/Vol5N9D1.pdf].

INSTITUTO DE CIENCIAS PENALES, "Memoria de las actividades desarrolladas entre los meses de abril de 1959 y marzo de 1960", Revista de Ciencias Penales, T. XIX, pp. 118-120.

- "Memoria de las actividades realizadas entre los meses de abril de 1966 y marzo de 1967”, Revista de Ciencias Penales, T. XXVI (1967), pp. 111-116.

— "Memoria de las actividades realizadas entre los meses de abril de 1967 y marzo de 1968", Revista de Ciencias Penales, T. XXVII (1968), pp. 99-103, p. 102).

— "Memoria de las actividades desarrolladas entre los meses de abril de 1970 y marzo de 1971 por el Instituto de Ciencias Penales", Revista de Ciencias Penales, T. XXX (1971), pp.107-110.

JAKOBS, Günther, "Schriftum: Oliver Sticht, 'Sachlogikals Naturrecht? Zur Rechtsphilosophie Hans Welzel (1904-1977)"', Goltdammer's Archiv für Strafrecht 148 (2001), pp. 492-494.

JESCHECK, Hans H.; WEIGEND, Thomas, Tratado de Derecho Penal, Parte General, Trad. de la $5^{\mathrm{a}}$ ed. Alemana (1996) por M. Olmedo, Granada: Comares, 2002.

JIMÉNEZ DE ASÚA, Luis, La Ley y el Delito, Curso de Dogmática Penal, Caracas: Andrés Bello, 1945.

- Tratado de Derecho Penal, T. I, $2^{a}$ ed. Actualizada, Buenos Aires: Losada, 1957.

- Tratado de Derecho penal, T. III, El delito, $3^{a}$ ed. Actualizada, Buenos Aires: Losada, 1965.

- El Criminalista, $2^{a}$ Serie, T. III, Buenos Aires: Zavala Ed., 1960.

- El Criminalista, $2^{a}$ Serie, T. I, Buenos Aires: Zavala, 1955.

- La teoría jurídica del delito (1931), $2^{a}$ Ed., Madrid: Dykinson, 2005, con "Estudio preliminar" y "Epílogo" de Enrique Bacigalupo.

LABATUT G., Gustavo, "Discurso pronunciado por don Gustavo Labatut G. En la recepción de don Luis Jiménez de Asúa como Miembro Honorario de la Facultad de Ciencias Jurídicas y Sociales de la Universidad de Chile", Revista de Ciencias Penales, T.XXX, No 1 (1971), pp. 40-42.

- Manual de Derecho penal, T. I., 3a ed., Santiago: Ed. Jurídica de Chile, 1958. 
MATUS, Jean Pierre "Origen, consolidación y vigencia de la

Nueva Dogmática Chilena (ca. 1955 1970)"

- Derecho penal, $9^{a}$ Ed. actualizada por Julio Zenteno Vargas, Santiago: Ed. Jurídica de Chile, 1990, 2 Vols., Vol. 1: parte general; Vol. 2: parte especial.

LARRAURI, Elena, La herencia de la criminología crítica, Madrid: Siglo XXI Ed., 1991.

LEONE, Giovanni, "El Tributo que la humanidad le debe a César Beccaria", T. XXIII (1964), pp. 3-18.

LUISI, Luiz, "La figura de Manuel de Rivacoba y Rivacoba", en Guzmán Dalbora (Coord.), El penalista liberal, pp.39-42.

MARTÍNEZ DE CODES, Rosa María, "Reflexiones en torno al criterio generacional, como teoría analítica y método histórico", Revista Quinto Centenario (U. Complutense de Madrid), Vol. 3 (1982), pp. 51 a 86.

MATUS A., Jean Pierre

- "Fernández, Fuenzalida y Vera: Comentaristas, autodidactas y olvidados. Análisis diacrónico y sincrónico de la doctrina penal chilena del siglo XIX", Ius et Praxis, Año 12, No 1 (2006), pp. 31-67.

— "Sergio Yáñez, obra e influencia. La dogmática chilena actual”, Revista de Derecho (Coquimbo), Año 14 (2007), No 1, pp. 113-130.

— "El positivismo en el Derecho penal chileno. Análisis sincrónico y diacrónico de una doctrina de principios del siglo XX que se mantiene vigente", Revista de Derecho Universidad Austral (Valdivia), Vol. XX, No 1 (2007), pp. 175-203.

- "Por qué citamos a los alemanes y otros apuntes metodológicos", Política $\begin{array}{llllll}\text { Criminal, } & \mathrm{N}^{\mathrm{o}} & 5 & \text { (2008), } & \text { A5-5. } & \text { pp. }\end{array}$ [http://www.politicacriminal.cl/n_05/a_5 5.pdf].

- "La política criminal de los tratados internacionales" (2009), en Carnevali, Cuestiones de politica criminal, pp. 105-134.

- "La doctrina penal de la (fallida) recodificación chilena del Siglo XX y principios del XXI", en Politica Criminal, Vol. 5, No. 9 (2010), Art. 4, pp. 143206, [http://www.politicacriminal.cl/Vol_05/n_09/Vol5N9A4.pdf ].

- La transformación de la Teoría del Delito en el Derecho penal internacional, Barcelona: Atelier, 2008.

MATUS, Jean Pierre; CARNEVALI, Raúl, “Análisis descriptivo y cuantitativo de los artículos de Derecho penal y Criminología de autores chilenos en Revistas publicadas en Chile (1885-2006), Política Criminal, №3 (2007), D2, pp. 1-138 [http://www.politicacriminal.cl/n_03/d_2 2 3.pdf].

MAURACH, Reinhart, Tratado de Derecho penal, Trad. J. Córdoba Roda, Barcelona: Ariel, 1962.

— "Les príncipes fundamentaux de la théorie de la loi pénal et de la construction du crime dan la partie générale du Project 1962", Revista de Ciencias Penales, T. XXIV (1965), pp. 121-137.

— "La fixation de la peine criminelle selon le droit actuell et le projet du 1962", Revista de Ciencias Penales, T. XXV (1966), pp. 26-39).

MAYER, Max Ernst, Derecho penal. Parte general (1915), Trad. S. POLITOFF, Montevideo: B de F, 2007.

MELENDO PARDOS, Mariano, “¿Strafrechtswissenschaft o Common Law? A propósito de Matus Acuña, Jean Pierre: La transformación de la teoría del delito en el derecho penal internacional,", Revista de Derecho Penal y Criminología,

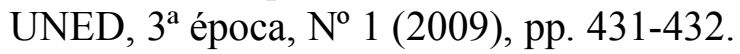

MEZGER, Edmund, Tratado de Derecho Penal, 2 Tomos, Trad. de la $2^{\text {a }}$ ed. Alemana (1932) por J. Rodríguez Muñoz, Madrid: Edersa, 1946.

- Moderne Wege der Strafrechtsdogmatik. Eine ergänzende Betrachtung zum 
Polit. crim. Vol. 6, № 11 (Julio 2011), Art. 3, pp. 44 - 105.

[http://www.politicacriminal.cl/Vol_06/n_11/Vol6N11A3.pdf]

Lehrbuch des Strafrechts in seiner 3. Auflage (1949), Berlín: Duncker \& Humblot, 1950.

- Derecho penal. Parte general, libro de estudio. Trad. de la $6^{\mathrm{a}}$ Ed. alemana (1955) por C. Finzi, Buenos Aires: Ed. Bibliográfica Argentina, 1958.

MONTERO S., Mario, "El pensamiento Jurídico Penal de Pedro Ortiz", en Revista de Ciencias Penales, T. X(1948), pp. 110-130, p. 112.

MUÑOZ CONDE, Francisco, Edmundo Mezger y el Derecho penal de su tiempo. Estudios sobre el Derecho penal en el Nacionalsocialismo, Valencia: Tirant Lo Blanch, 2002.

NOVOA Monreal, Eduardo, Teoría del Consentimiento de la Víctima del Delito, Tesis UCh, Santiago: Talleres Gráficos La Nación, 1939.

- "La obligación jurídica del secreto profesional", Revista de Derecho y Jurisprudencia, T. XLI (1944), pp. 85-100.

— "El delito de homicidio y la intención de matar", Revista de Ciencias Penales, T. VIII (1945), pp. 183-192.

— "El concepto de abusos deshonestos", Revista de Ciencias Penales, T. IX (1946), pp. 291-298.

— "Pedro Ortiz Muñoz", Revista de Ciencias Penales, T. IX (1946), № 2, p. v-vi.

- "Cuestiones jurídicas relativas al delito de amenazas", Revista de Ciencias Penales, T. XII (1950), pp. 15-23.

- Los elementos del delito. Explicación elemental sobre su estructuración sistemática en el concepto jurídico-penal, Santiago: apartado de los $<<$ Anales Jurídico-sociales $>>$ (Universidad Católica de Chile), Año XXXVII, Número Noveno, 1952.

— "La conducta, primer elemento del delito", Revista de Ciencias Penales, T. XVIII (1959), p. 3-21.

— "Algunas consideraciones acerca de la tentativa", Revista de Ciencias Penales, Tomo XIX (1960), pp. 3-32.

- Curso de Derecho Penal, T. I, Santiago: Ed. Jurídica, 1960.

— "La legislación penal económica" (1962), en Univ. Católica, La Nueva Legislación y el Desarrollo Económico de Chile, pp. 151-177.

- El trasplante de corazón. Aspectos Médico-Legales, Éticos y Jurídicos, Santiago: Ed. Universitaria, 1969.

- Causalismo y Finalismo en Derecho Penal (Aspectos de la enseñanza penal en Hispanoamérica), San José de Costa Rica: Ed. Juricentro, 1980.

- Fundamentos de los delitos de omisión, Buenos Aires: Depalma, 1984.

- Los resquicios legales. Un ejercicio de lógica jurídica, Santiago: Ed. Bat, 1992.

OPAZO, Cristián, Luis Cousiño Mac Iver: Vida, obra e influencia en el Derecho Penal actual, Tesis UTal, Talca: 2006 (Prof. Guía: JP MATUS).

ORREGO V., Germán, Delitos de imprenta o de publicación, Tesis UCh, Santiago, 1937.

ORTIZ MUÑOZ, Pedro, Nociones Generales de Derecho Penal, T. I, Santiago: Editorial Nascimento, 1933.

- Curso Breve de Derecho Penal (Común y Militar), Santiago: Imp. de Carabineros, 1947.

ORTIZ QUIROGA, Luis, Teoría de las hipótesis preterintencionales, Tesis UCh, Santiago: Ed. Jurídica, 1959.

— "Algunas consideraciones sobre la teoría de la acción finalista", Revista de 
MATUS, Jean Pierre "Origen, consolidación y vigencia de la

Nueva Dogmática Chilena (ca. 1955 1970)"

Ciencias Penales, T. XXIV (1965), pp. 3-20 (primera parte) y 101-120 (segunda parte).

— "Dolo y conciencia del injusto en la ley penal chilena", en SCHWEITZER W., Nullum crimen, pp. 279-294).

PICA URRUTIA, René, Desarrollo práctico de las reglas para la aplicación de las penal, según las atenuantes y agravantes que concurran o falten (Código Penal y Ley $N^{\circ}{ }^{6}$ 6,026, sobre Seguridad Interior del Estado, con las modificaciones que le introdujo la, Ley N. ${ }^{\circ}$ 8,987, sobre Defensa de la Democracia), Tesis UCh, Santiago: IMP de Carabineros, 1948.

PILCHER, Jane, "Mannheim's sociology of generations: an undervalued legacy", British Journal of Sociology, Vol. 43, No 3 (1944), pp. 481-495.

PINOCHET ESPINOSA, Ramón, La recuperación social de varones condenados o encausados, Tesis UCh, Santiago, 1951.

PIÑA, Juan Ignacio, Derecho penal, fundamentos de la responsabilidad, Santiago: Abeledo Perrot, 2010.

POLAINO NAVARRETE, Miguel, "Semblanza personal y universitaria de Manuel de Rivacoba y Rivacoba (1925-2000)", en GUZMÁN DALBORA (Coord.), El penalista liberal, pp.19-38.

POLITOFF L., Sergio; BUSTOS R., Juan; FLISFISCH, Claudio, “Omisión de socorro y homicidio por omisión”, Revista de Ciencias Penales, T. XXV (1966), pp. 163185.

POLITOFF Lifschtiz, Sergio, "Prenda, Depósito y Mandato en la Teoría de la Apropiación Indebida", Revista de Ciencias Penales, T. XVI (1956), pp. 9-50. — "Gustavo Labatut Glena (1896-1963)", Revista de Ciencias Penales, T. XXII (1963), p. 166.

- Los elementos subjetivos del Delito, Santiago: Ed. Jurídica de Chile, 1965.

- El delito de apropiación indebida, Santiago: Ed. Nascimento, 1957.

— “El nuevo Código penal de la República Democrática Alemana”, Revista de Ciencias Penales, T. XXIX (1970), pp. 3-14.

— "Derecho penal con mesura: una respuesta reduccionista a la mala conciencia del jurista", Revista Universum (Universidad de Talca), Año 10 (1995), pp. 95106.

- Los actos preparatorios del delito tentativa y frustración: estudio de dogmática penal y de derecho penal comparado, Santiago: Ed. Jurídica, 1999.

- Derecho Penal, Tomo I, $2^{a}$ ed., Santiago: Conosur, 2000.

POLITOFF L., Sergio; BUSTOS R., Juan; GRISOLÍA, Francisco, Derecho penal chileno, parte especial, T. I. Delitos contra el individuo en sus condiciones físicas, Santiago: Ed. Jurídica de Chile, 1971.

POLITOFF L., Sergio; MATUS A., Jean Pierre (Eds.), Lavado de dinero y tráfico ilicito de estupefacientes, Santiago: LexisNexis, 1999.

POLITOFF L:, Sergio; MATUS A., Jean Pierre; RAMÍREZ G., Ma Cecilia, Lecciones de Derecho Penal Chileno, Santiago: Ed. Jurídica de Chile, 2004 (Parte General) y 2005 (Parte Especial).

REYES, Fernando, "Contribución al debate sobre la conveniencia de incriminar el adulterio del marido", Revista de Ciencias Penales T. XXII (1963), pp. 304-313.

RIVACOBA Y RIVACOBA, Manuel de, Actas de las Jornadas Internacionales de Derecho penal en celebración del centenario del Código penal Chileno (Ed.), Valparaíso: Edeval, 1974.

— "El principio de culpabilidad en el Código penal chileno", en del mismo (Ed.), Actas, pp. 49-126. 
Polít. crim. Vol. 6, No 11 (Julio 2011), Art. 3, pp. 44 - 105.

[http://www.politicacriminal.cl/Vol_06/n_11/Vol6N11A3.pdf]

— "Pensamiento penal y criminológico del Código penal tipo para Iberoamérica", Doctrina Penal, Año 10, Ns 37 a 40 (1987), pp. 713-734.

RIVADENEIRA, Ricardo, "Balance y diagnóstico de la legislación actual en materia de corrupción”, Revista de Ciencia Política, Vol. 18, nos. 1-2 (1996), pp. 91-97.

ROSAL, Juan del, "Meditación crítica sobre la modificación de los delitos de la circulación", Revista de Ciencias Penales T. XXVII (1968), pp. 3-34.

ROXIN, Claus, Strafrecht. Allgemeiner Teil. Band I, Grundlagen. Der Aufbau der Verbrechenslehre, 2. Aufl., München: Verlag C.H. Beck, 1994.

SAUER, Wilhelm, Derecho Penal (Parte General), Barcelona: Bosch, 1956, Trad. de Juan del Rosal y José Cerezo Mir de la $3^{\mathrm{a}}$ ed. alemana de 1955.

SCHÖNE, Wolfgang, "Menores disociales en la República Federal Alemana", Revista de Ciencias Penales, T. XXVIII (1969), pp. 99-118.

SCHWEITZER Speisky, Daniel, "el Delito del artículo 212 del Código penal”, Revista de Ciencias Penales, T. XV (1956), pp. 5-8.

SCHWEITZER Speisky, Miguel, "El delito de acusación o denuncia calumniosa", Revista de Ciencias Penales, T. III (1937), pp. 342-359.

- “Síntesis de la legislación chilena de menores", Revista de Ciencias Penales, T. IV (1938), pp. 310-316.

- “El 'principio de ejecución' en el delito de violación”, Revista de Ciencias Penales, T. VIII (1945), pp. 25-28.

- "Discurso de recepción del profesor de derecho penal [Rafael Fontecilla]", Anales de la Facultad de Ciencias Jurídicas y Sociales, Vol. III, N ${ }^{\circ}$ 3 (1961 a 1963), p. 90s.

- "Discurso pronunciado por el señor Miguel Schweitzer S., en el Instituto de Ciencias Penales, al ser recibido como Miembro Honorario el Profesor Sr. Luis Jiménez de Asúa, en la sesión de fecha 26 de noviembre de 1942", Revista de Ciencias Penales, T.XXX, No 1 (1971), pp. 38-40.

SCHWEITZER Walters, Miguel, El error de derecho en materia penal, Tesis Uch, Santiago: Ed. Jurídica, 1964.

— "Sobre los delitos de la Ley de Quiebras", Revista de Ciencias Penales, T. XXVI (1967), pp. 151-161.

- Nullum crimen, nulla poena sine lege. Homenaje a grandes penalistas chilenos (Coord.), Santiago: Ed. U. Finis Terrae, 2010.

SILVA SÁNCHEZ, Jesús María, Aproximación al Derecho penal contemporáneo, Barcelona: Bosch, 1992, pp. 68-72.

- La expansión del Derecho penal, Aspectos de la política criminal en las sociedades postindustriales, $2^{a}$ ed., Madrid, 2001.

SOTO, Miguel, "Una jurisprudencia histórica: hacia el reconocimiento del principio de culpabilidad en el Derecho penal chileno", Revista de Derecho U. Finis Terrae, No 3 (1999), pp. 233-253.

ULlOA U., Joselyn, Vida, obra e influencia en el Derecho penal chileno de Sergio Yáñez Pérez, Tesis UTal, Talca, 2006 (Prof. Guía: JP Matus).

UNIVERSIDAD CATÓLICA DE CHILE, Facultad de Ciencias Jurídicas, Políticas y Sociales, La Nueva Legislación y el Desarrollo Económico de Chile. Ciclo de Conferencias, Julio-Septiembre, 1962, Santiago: Editorial Universidad Católica, 1962.

UNIVERSIDAD DE CHILE, Catálogo de la Biblioteca de Ciencias Jurídicas y Sociales, Santiago: Imp. Dir. Gral. de Prisiones, 1940,

- Anales de la Facultad de Ciencias Jurídicas y Sociales (Derecho), varios tomos entre 1937-1972. 
MATUS, Jean Pierre "Origen, consolidación y vigencia de la

Nueva Dogmática Chilena (ca. 1955 1970)"

URIBE A., Armando, De los delitos calificados por el resultado, Tesis UCh, Santiago: Ed. Jurídica, 1957.

- Repertorio de las palabras de la ley penal chilena, Santiago: Ed. Jurídica, 1965.

VALENCIA Martínez, Jorge, "Recuerdo de Manuel de Rivacoba y Rivacoba", en GUZMÁN DALBORA (Coord.), El penalista liberal, pp.43-46.

VASSALLI, Giulano, "Criminología y Justicia Penal”, Revista de Ciencias Penales, T. XIX (1960), pp. 3-50.

VILLALONGA T., Cristián, Introducción a la política-jurídica en Eduardo Novoa (Desde una teoría crítica del Derecho a la vía legal al socialismo durante la Unidad Popular), Santiago. Tesis PUC, 2003 (Prof. Guía: C. Frontaura).

VILLAR Brito, Waldo del, Malversación de caudales públicos, Tesis UCh, Valparaíso, Imp. Dir. Gral. De Prisiones, 1948.

VILLEGAS, Myrna (Coord.), Contribuciones críticas al sistema penal de la post modernidad, in memoriam a Eduardo Novoa Monreal, Santiago: U. Central, 2007.

VIVANCO S., Jaime, El delito de robo con homicidio. Ensayo a la luz de la doctrina del delito-tipo, Tesis UCh, Santiago: Ed. Jurídica, 1957.

- El Delito deRobo con Homicidio, $2^{a}$ ed., Santiago: Ed. Conosur, 2000.

WELZEL, Hans, Das Deutsche Strafrecht in seinen Grundzügen, $3^{a}$ ed., Berlín: De Gruyter, 1944.

- La teoría de la acción finalista, Trad. C. Fontán B., Buenos Aires: Depalma, 1951.

- Derecho penal. Parte general, Trad. C. Fontán B., Buenos Aires: Depalma, 1956.

- Derecho penal alemán, $11^{a}$ ed., Trad. J. Bustos y S. Yáñez, Santiago: Ed. Jurídica, 1969.

YÁÑEZ Pérez, Sergio, “Comentario del Libro Derecho Penal Chileno: Parte General (Tomo I)", Revista de Ciencias Penales, T. XXXIV, No 2 (1975), p. 240.

- "Problemas básicos de la autoría y la participación en el Código penal chileno", en Rivacoba (ed.), Actas, pp. 161-181.

— "La evolución del sistema del Derecho penal", Cuadernos de Política Criminal, No 54 (1994), pp. 1153-1209.

ZENTENO Vargas, Julio, Del régimen de la propiedad austral y de la prescripción de corto tiempo regida por el decreto con fuerza de ley $N^{o} 260$, Tesis UCh, Santiago: Impr. Direcc. Gral. de Prisiones, 1941.

— “La comunidad y el Terrorismo", Revista Temas de Derecho, Año IV, No 1 (1989), pp.26-28. 